\title{
Hypoxia-inducible factor 1 alpha
}

\section{- dependent and independent regulation of hematopoietic stem cells and leukemia}

\author{
Camilla Halvarsson
}

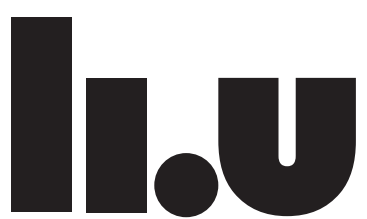

LINKÖPING UNIVERSITY

Department of Clinical and Experimental Medicine Division of Hematopoiesis and Developmental Biology

Faculty of Medicine and Health Sciences Linköping University, SE-58183 Linköping, Sweden Linköping 2018 
(C) Camilla Halvarsson, 2018

Cover: Rada Ellegård

Published articles have been reprinted with permission of the copyright holders:

Paper I (C 2017 PLoS

Paper III @ 2012 ISEH - Society for Hematology and Stem Cells

During the course of the research underlying this thesis, Camilla Halvarsson was enrolled in Forum Scientium, a multidisciplinary doctoral program at Linköping University, Sweden.

ISSN 0345-0082

ISBN 978-91-7685-210-1

Printed by LiU-Tryck, Linköping, Sweden, 2018. 
Hypoxia-inducible factor 1 alpha

- dependent and independent regulation of hematopoietic stem cells and leukemia

By

Camilla Halvarsson

December 2018

ISBN 978-91-7685-210-1

Linköping University Medical Dissertation No. 1643

ISSN 0345-0082

Keywords: Hematopoietic stem cells, hypoxia, hypoxia inducible factor 1 alpha, pyruvate dehydrogenase kinase 1, metabolism, glycolysis, transplantation, nuclear factor kappaB, oxidative stress, myeloid leukemia, chemotherapy, ABC genes, drug resistance

Department of Clinical and Experimental Medicine

Linköping University

SE-581 83 Linköping, Sweden 
Till Ramy, Rut (b) Suar

Klockan fem på morgonen är världen din. Då har ingen annan varit framme och fingrat på den. - livet.se

There is nothing like looking, if you want to find something. You certainly usually find something, if you look, but it is not always quite the something you were after. - J.R.R. Tolkien 
Supervisor:

\section{Jan-Ingvar Jönsson}

Division of Hematopoiesis and Developmental Biology

Department of Clinical and Experimental Hematology

Linköping University, Sweden

Co-supervisor:

\section{Mikael Sigvardsson}

Division of Hematopoiesis and Developmental Biology

Department of Clinical and Experimental Hematology

Linköping University, Sweden

Faculty opponent:

\section{Kamil Kranc}

Centre for Haemoto-Oncology

Barts Cancer Institute, Queen Mary University of London

London, United Kingdom 



\section{ABSTRACT}

This thesis has studied the role of low oxygen levels, or hypoxia, in hematopoietic stem cells (HSCs) and how, at the molecular level, it regulates stem cell maintenance and protects against oxidative stress induced by reactive oxygen species (ROS). HSCs reside within the bone marrow in specific niches created by a unique vascularized environment, which is suggested to be hypoxic and crucial for HSCs by maintaining a quiescent state of cell cycle and by redirecting metabolism away from the mitochondria to glycolysis. The niches are also believed to limit the production of ROS, which could damage DNA and disrupt the stem cell features. The hypoxia-responsive protein hypoxia-inducible factor 1 alpha (HIF-1 $\alpha)$ is a major regulator of the hypoxic cell response in HSCs as well as in leukemic stem cells. Both these cells are thought to reside in the bone marrow where they are protected from stress and chemotherapy by niche cells and hypoxia.

The thesis demonstrates that pyruvate dehydrogenase kinase 1 regulates a metabolic shift to glycolysis, and maintains the engraftment potential of both HSCs and multipotent progenitors upon transplantation. Furthermore, we wanted to determine whether HIF-1 $\alpha$ or other signaling pathways are involved in protecting HSCs from ROS-induced cell death. Overexpression, silencing or a knockout mouse model of Hif- $1 \alpha$ could not identify HIF-1 $\alpha$ as important for protecting HSCs from oxidative stress-induced cell death through inhibition of synthesis of the antioxidant glutathione. Gene expression analysis instead identified the transcription factor nuclear factor kappa $\mathrm{B}(\mathrm{NF}-\kappa \mathrm{B})$ as induced by hypoxia. By studying NF$\kappa \mathrm{B}$ signaling we found increased $\mathrm{NF}-\kappa \mathrm{B}$ activity in cells cultured in hypoxia compared to normoxia. Suppression of inhibitor of kappa B indicated a putative role of NF- $\kappa$ B signaling in hypoxia-induced protection against oxidative stress. The findings show that hypoxia-induced protection to elevated levels of ROS upon glutathione depletion seems to be attributed to activation of the NF- $\kappa \mathrm{B}$ signaling pathway independently of HIF-1 $\alpha$.

To address the question whether hypoxic in vitro cultures support maintenance and promote HSC expansion we performed a limited dilution-transplantation assay. Our data indicate that hypoxic cultures maintain more long-term-reconstituting HSCs than normoxia, but this could not be confirmed statistically. Finally, we wanted to study the mechanisms by which hypoxia protect against chemotherapy. We could demonstrate that hypoxic culture protects leukemic cell lines against apoptosis induced by chemotherapy or inhibitors used for treatment of leukemia. This multidrug resistance seems to be mediated by ATP-binding cassette transporter genes, which are upregulated by hypoxia and whose inhibition has been shown to increase chemosensitivity. In addition, HIF-1 $\alpha$ was upregulated in the leukemic cell lines in hypoxia and its inhibition increased the sensitivity to chemotherapy, indicating a role in inducing chemotherapy resistance.

Conclusively, the results presented in this thesis stress the importance of hypoxia in regulating metabolism, oxidative-stress response and maintenance of both HSCs as well as leukemic cells, especially through the critical transcription factors HIF- $1 \alpha$ and NF- $\kappa \mathrm{B}$ and their target genes. 



\section{TABLE OF CONTENTS}

ARTICLES AND MANUSCRIPTS INCLUDED IN THIS THESIS …............................. 1

POPULÄRVETENSKAPLIG SAMMANFATTNING ............................................. 3

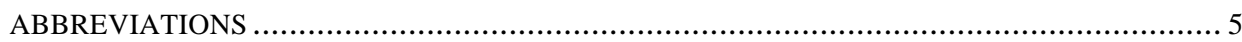

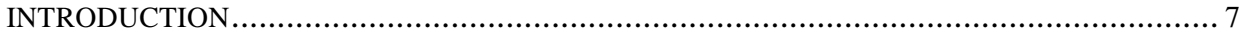

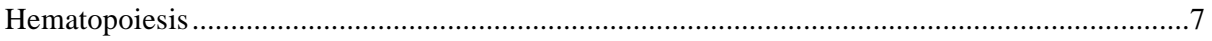

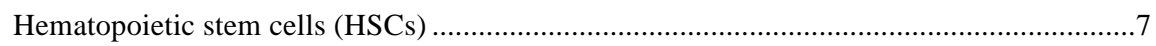

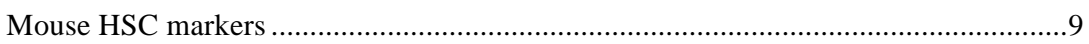

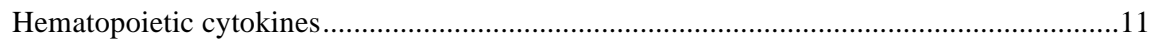

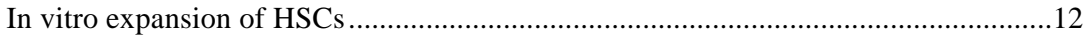

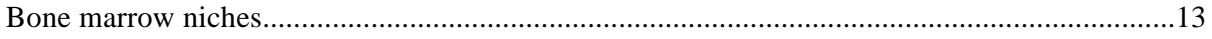

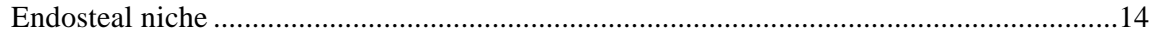

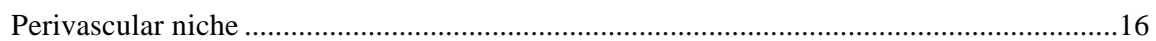

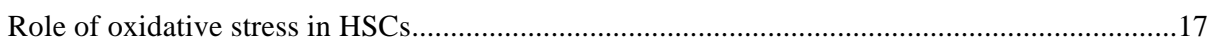

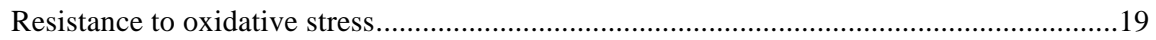

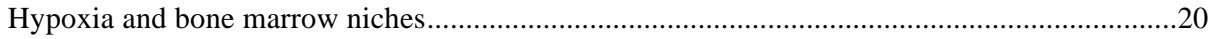

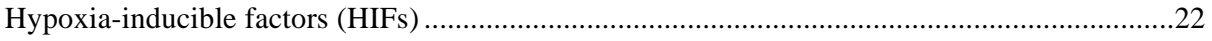

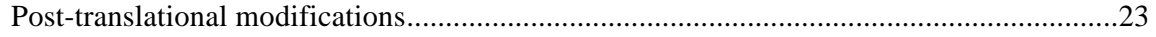

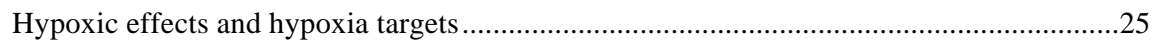

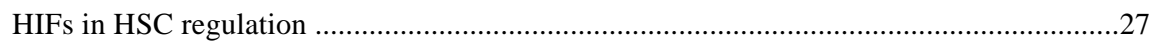

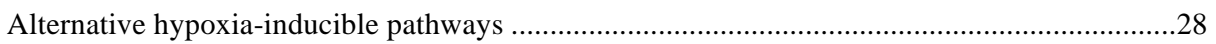

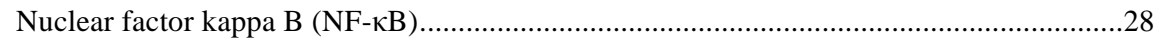

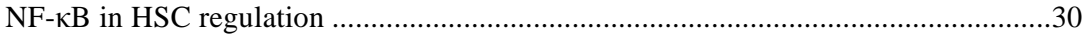

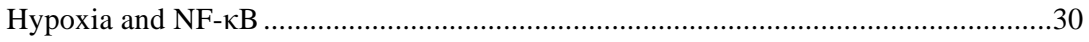

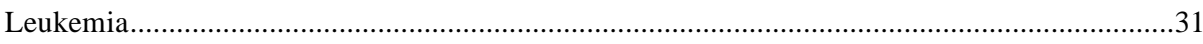

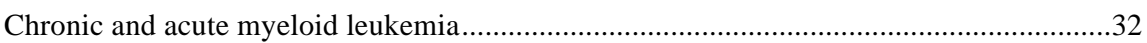

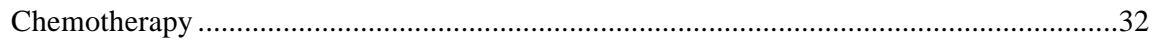

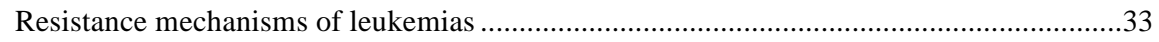

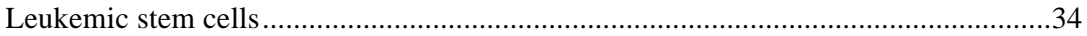

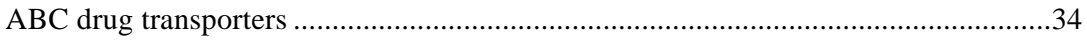

Alternative resistance mechanisms ...........................................................................

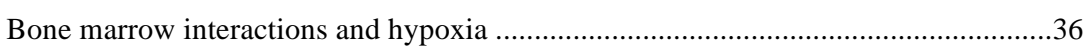

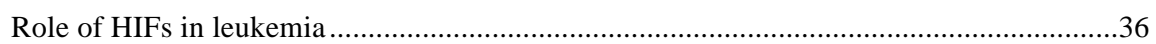

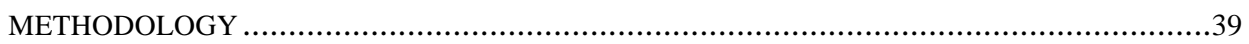

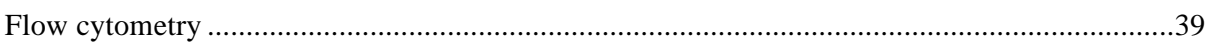

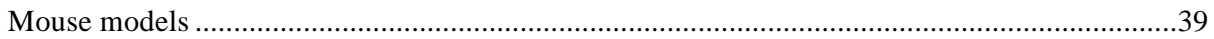




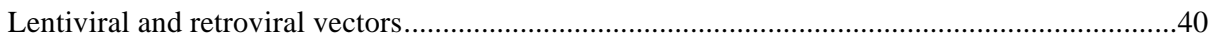

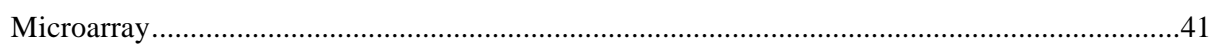

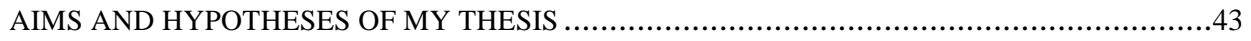

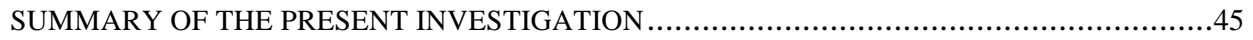

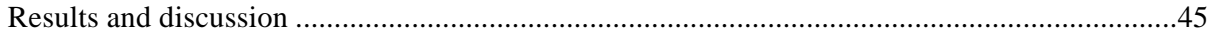

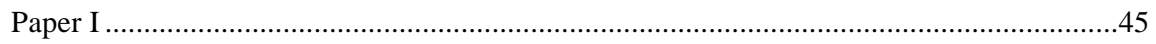

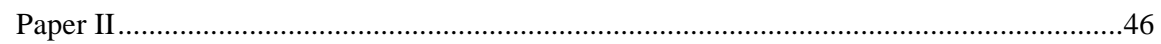

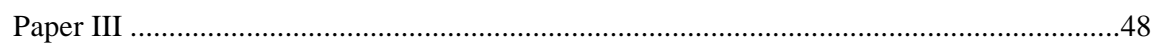

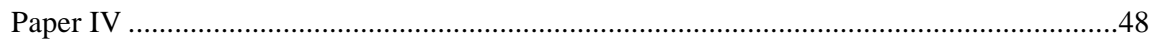

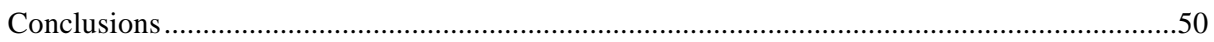

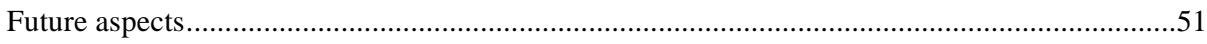

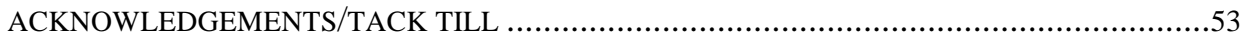

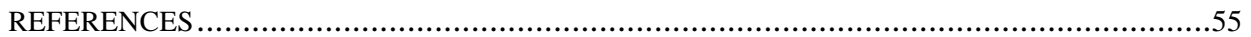




\section{ARTICLES AND MANUSCRIPTS INCLUDED IN THIS THESIS}

This thesis is based on the following articles, which will be referred to in the text by their roman numerals (I-IV).

I. Camilla Halvarsson, Pernilla Eliasson, Jan-Ingvar Jönsson. Pyruvate dehydrogenase kinase 1 is essential for transplantable mouse bone marrow hematopoietic stem cell and progenitor function.

PLoS One. 2017 Feb 9;12(2):e0171714

II. Camilla Halvarsson, Emma Rörby, Pernilla Eliasson, Stefan Lang, Shamit Soneji, Jan-Ingvar Jönsson. Hypoxia maintains NF- $\kappa \mathrm{B}$ signaling and protects hematopoietic stem and progenitor cells from induced oxidative stress.

Manuscript submitted to Antioxidants \& Redox Signaling, under revision

III. Yanjuan Tang*, Camilla Halvarsson*, Pernilla Eliasson, Jan-Ingvar Jönsson. Hypoxic and normoxic in vitro cultures maintain similar numbers of long-term reconstituting hematopoietic stem cells from mouse bone marrow.

Experimental Hematology. 2012 Nov;40(11):879-81

IV. Maria del Mar Arriero, Camilla Halvarsson, Pia Druid, Linda Schneider, Sara Söderquist, Henrik Gréen, Jan-Ingvar Jönsson. Human leukemia cell lines develop multidrug resistance during exposure to hypoxia.

Manuscript

$*$ = equal contribution 


\section{POPULÄRVETENSKAPLIG SAMMANFATTNING}

Då de flesta celler i kroppen med jämna mellanrum måste bytas ut finns det i olika organ stamceller som har en unik förmåga att ge upphov till olika celltyper men även att bilda en kopia av sig själv. På så vis säkerställer stamcellerna att gamla eller skadade celler ersätts av nya under hela människans liv. Det finns olika typer av stamceller i människans organ, exempelvis huden, tarmen och blodet. Stamcellen som bildar olika typer av blodceller som syretransporterande röda blodkroppar, vita blodkroppar som bygger upp immunförsvaret samt blodplättar som stoppar blödning kallas blodstamcell, eller hematopoietisk stamcell. Varje dag kan denna lilla population av stamceller göra $10^{12}$ blodceller, vilket för att förstå den enorma mängden kan jämföras med att lika många minuter motsvarar ungefär 1,9 miljoner år. Blodstamceller har visat sig finnas på olika ställen i kroppen, i benmärgen som finns inuti skelettet, där andra typer av celler genom kontakt eller genom att skicka "meddelanden" via molekyler som binder till mottagare på stamcellens yta ger instruktioner så som "Förbli vilande" eller "Bilda mer blodceller" och på detta sätt reglerar att blodstamcellen inte delar sig för ofta.

Förutom det komplicerade nätverk av celler som på olika sätt kontrollerar blodstamcellen utifrån så kan cellen i sig själv skicka signaler som utgår från den själv. Utöver detta så har det även visats att benmärgen kännetecknas av låg syrenivå, kallat hypoxi. Hypotesen för mitt avhandlingsarbete var att detta skyddar blodstamcellen från små partiklar som kallas fria syreradikaler och som annars skulle kunna skada viktiga delar i cellen. Om detta skydd eller den låga syrenivån inte fungerar skulle det kunna leda till att blodstamcellen förlorar sin livsnödvändiga förmåga att bilda nya blodceller. Då skulle kroppen snabbt börja tömmas på blodceller och utsättas för blodbrist eller infektioner, med andra ord ett livshotande tillstånd.

Vi har studerat blodstamceller från möss och kunnat visa att om dessa celler tas ut från musen och odlas i hypoxi så producerar de ett protein som gör att de anpassar sig till den låga halten av syre. Detta protein i sin tur styr produktionen av många andra proteiner, varav ett är involverat i cellens energiproduktion. Om man hindrar cellen från att producera proteinet som ger signalen "Producera mindre energi!" och stoppar in blodstamcellerna i nya möss, så har de sämre förmåga att bilda nya blodceller än normala blodstamceller. Detta visar hur viktigt detta protein är för att blodstamcellerna ska kunna klara låg syrenivå. Vi har även kunnat visa genom att odla blodstamceller i hypoxi att lågt syre skyddar cellerna från skador av fria syreradikaler som annars kan skada cellernas DNA och proteiner.

Blodcancer, även kallat leukemi, är en sjukdom där vita blodkroppar delar sig okontrollerat vilket leder till att blodbildningen störs och att en stor mängd sjuka celler tar över. Det har visat sig att det även finns leukemistamceller, och att dessa precis som normala blodstamceller kan dra nytta av skyddet $\mathrm{i}$ benmärgen och på detta vis undkomma många av de behandlingar som sätts in vid sjukdomen. Då många leukemier kännetecknas av att behandling först har effekt men att patienterna sedan får återfall och avlider, så är behovet av att förstå vilka förändringar inuti och utanför blodcellen som leder till leukemi stort för att nya läkemedel ska kunna utvecklas. 
Vi har studerat om hypoxi kan skydda leukemiceller från olika typer av läkemedel och om det på så sätt bibehåller sjukdomen. Med hjälp av celler isolerade från patienter med leukemi har vi kunnat visa att leukemicellerna var mer motståndskraftiga mot läkemedel om de odlades i hypoxi.

Sammanfattningsvis visar resultaten i min avhandling på betydelsen av hypoxi att skydda både blodstamceller och leukemiceller mot stress i olika former. Även om studierna är utförda på blodstamceller från möss tror vi att detta kan öka förståelsen för blodstamceller hos människa. Genom en ökad kunskap om hur blodstamceller skyddas mot stress i olika former, i synnerhet läkemedel, skulle nya behandlingsformer mot leukemi kunna utvecklas. 


\section{ABBREVIATIONS}

$\mathrm{ABC}=\mathrm{ATP}-$ binding cassette

$\mathrm{AML}=$ acute myeloid leukemia

BCL-2 = B-cell lymphoma 2

$\mathrm{BM}=$ bone marrow

$\mathrm{BSO}=\mathrm{DL}-$ buthionine-(S,R)-sulfoximine

$\mathrm{CML}=$ chronic myeloid leukemia

$\mathrm{CMP}=$ common myeloid progenitor

$\mathrm{CXCL}=$ chemokine $(\mathrm{C}-\mathrm{X}-\mathrm{C}$ motif $)$ ligand

$\mathrm{CXCR}=\mathrm{C}-\mathrm{X}-\mathrm{C}$ chemokine receptor type

DMOG = dimethyloxalylglycine

$\mathrm{EC}=$ endothelial cell

FACS $=$ fluorescence-activated cell sorting

$\mathrm{FIH}=$ factor-inhibiting HIF- $\alpha$

FLT3 = fms-like tyrosine kinase 3

$\mathrm{GFP}=$ green fluorescent protein

$\mathrm{GSH}=$ reduced glutathione

$\mathrm{H}_{2} \mathrm{O}_{2}=$ hydrogen peroxide

$\mathrm{HIF}=$ hypoxia-inducible factor

HRE = hypoxia response elements

HSC $=$ hematopoietic stem cell

HSPC $=$ hematopoietic stem and progenitor cell

$\mathrm{I} \kappa \mathrm{B}=$ inhibitor of kappa $\mathrm{B}$

$\mathrm{IKK}=\mathrm{I} \kappa \mathrm{B}$ kinase
LSC = leukemic stem cell

LSK $=$ Lineage ${ }^{-}$Sca- $1^{+}$c-kit ${ }^{+}$

LT-HSC $=$ long-term hematopoietic stem cell

MDR = multidrug resistance

$\mathrm{MPP}=$ multipotent progenitor

mRNA $=$ messenger-RNA

$\mathrm{NF}-\kappa \mathrm{B}=$ nuclear factor kappa $\mathrm{B}$

$\mathrm{O}_{2}{ }^{-}=$superoxide anion radical

$\mathrm{OB}=$ osteoblast

PDK = pyruvate dehydrogenase kinase

PHD = prolyl hydroxylase domain

q-PCR = quantitative real-time PCR

ROS $=$ reactive oxygen species

$\mathrm{RTK}=$ receptor tyrosine kinase

$\mathrm{SCF}=$ stem cell factor

shRNA = short hairpin RNA

siRNA = small interfering RNA

$\mathrm{SOD}=$ superoxide dismutase

ST-HSC $=$ short-term hematopoietic stem cell $\mathrm{TPO}=$ thrombopoietin

VEGFA = vascular endothelial growth factor $\mathrm{A}$

VHL = von Hippel-Lindau protein 


\section{INTRODUCTION}

\section{Hematopoiesis}

Hematopoiesis, the formation of blood cells, is a complex process that is tightly controlled in order to produce and continuously replace mature blood cells with finite life span and govern functions essential for everyday survival. During embryogenesis blood cell development takes place at many sites before hematopoietic stem cells (HSCs) colonize the bone marrow (BM) for lifelong production of blood cells.

Red blood cells, granulocytes, lymphoid cells, monocytes and platelets are responsible for distribution of oxygen to all cells of the body, defense against infection and regulation of blood clotting. The turnover of blood cells ranges from hours (granulocytes), months (erythrocytes) up to years (lymphocytes) (Lensch, 2012). Due to the short life span of many of the blood cells, every day around 1 trillion $\left(10^{12}\right)$ new cells need to be produced in an adult human to maintain homeostasis (Ogawa, 1993). All these cells arise from the HSC, a rare cell that throughout lifetime can both self-renew through symmetric division and produce multipotent progeny cells by asymmetric division (Molofsky et al., 2004). The progenitor cells with limited self-renewal capacity thereafter go through several steps of proliferation and differentiation where the cells stepwise restrict their lineage potential, becoming precursor cells lacking self-renewal potential and finally differentiating into mature blood cells.

\section{Hematopoietic stem cells (HSCs)}

The HSCs are defined as capable of self-renewing themselves for lifetime and producing all hematopoietic progenitors (Figure 1), as well as through their repopulation capacity i.e. being able to re-establish blood formation upon transplantation. In 1961 James Till and Ernest McCullough were the first to define these hematopoietic stem cell hallmarks experimentally as well as providing methods for stem cell testing. By transplantation of BM cells to irradiated mice the production of colonies in the spleen, colony-forming unit spleen (CFU-S), in direct proportion to the number of injected BM cells and originating from different hematopoietic lineages were identified (Becker et al., 1963; Till \& Mc, 1961).

As already mentioned HSCs are rare cells, constituting $0.005-0.01 \%$ of total BM cells in adult mice (Challen et al., 2009; Ema et al., 2006), lacking morphological characteristics that distinguish them from white blood cells. The primitive HSC functionality can only be proved upon transplantation to irradiated mice and detected by the reconstitution of all hematopoietic lineages in the recipient BM, peripheral blood and spleen or thymus (Kent et al., 2007). However, by labeling cell surface markers with specific antibodies stem cells can be enriched by fluorescence-activated cell sorting (FACS) (see section Methodology, page 39). 


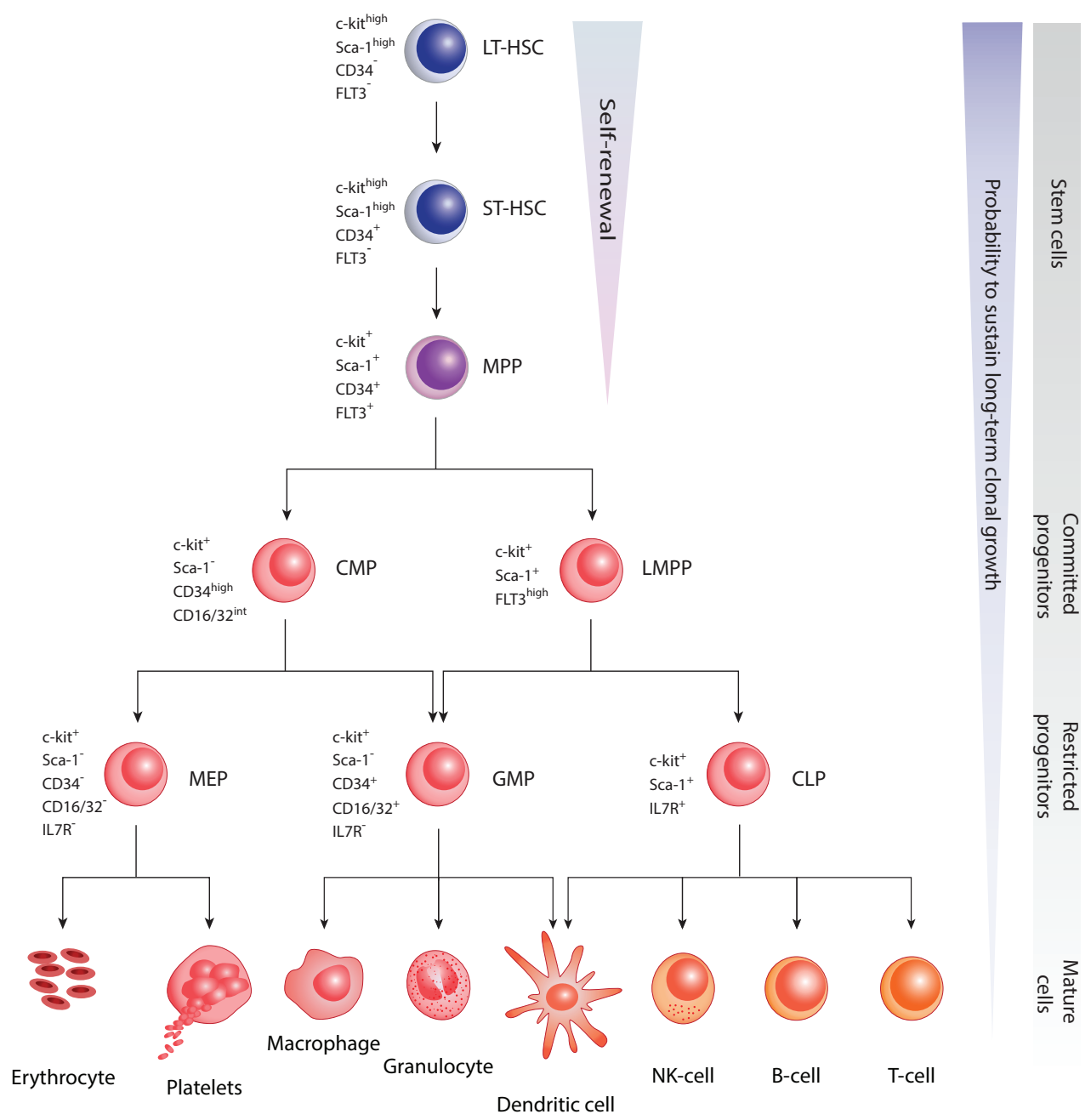

Figure 1. Schematic drawing of the hematopoietic hierarchy. The hematopoietic hierarchy showing a few of the differentiation steps from HSC to mature blood cells, by which HSCs produce progenitor cells with progressively decreased multipotency and self-renewal capacity as indicated. HSCs are divided in long-term (LT)-HSCs, short-term (ST)-HSCs and MPPs. The phenotypic cell surface markers of each population of murine blood cells are shown. CLP, common lymphoid progenitor; CMP, common myeloid progenitor; GMP; granulocyte/macrophage progenitor; HSC, hematopoietic stem cell; LMPP, lymphoid-primed multipotent progenitor; MEP, megakaryocyte/erythrocyte progenitor; MPP, multipotent progenitor. Adapted with modifications from Emma Rörby (Rörby, 2014), with permission. 


\section{Mouse HSC markers}

One of the central questions in stem cell biology is to identify markers that distinguish stem cells from their progenitors. Since the HSC is not committed to any mature blood cell type it does not express lineage specific cell surface markers such as CD3, CD4, CD8 (T cells), Gr-1 (granulocytes), Ter-119 (erythrocytes), Mac-1 (monocytic cells and macrophages) and B220 (B cells and NK cells) (Spangrude et al., 1988) or CD19 (B cells) (Rolink et al., 1996). With the discovery of expression of stem cell antigen (Sca-1) (Spangrude et al., 1988) and the cytokine receptor tyrosine kinase (RTK) c-kit (CD117) (Ikuta \& Weissman, 1992; Ogawa et al., 1991) the murine compartment called lineage ${ }^{-}\left(\mathrm{Lin}^{-}\right) \mathrm{Sca}^{-1}{ }^{+} \mathrm{c}-\mathrm{kit}^{+}$(LSK) was revealed. It constitutes $0.05-0.1 \%$ of total $\mathrm{BM}$ cells and contains nearly all cells with selfrenewal capacity (Ikuta \& Weissman, 1992; Li \& Johnson, 1995; Okada et al., 1992), making it the most common antigen set for murine HSC purification.

The LSK compartment can be divided into three distinct populations: long-term (LT)HSCs lacking expression of CD34 and fms-like tyrosine kinase 3 (FLT3), short-term (ST)HSCs $\left(\mathrm{CD} 34^{+} \mathrm{FLT}^{-}\right)$and multipotent progenitors (MPPs) $\left(\mathrm{CD} 34^{+} \mathrm{FLT}^{+}\right.$) (Adolfsson et al., 2001; Christensen \& Weissman, 2001; Yang et al., 2005). These populations give rise to a sequential order of HSCs, from LT-HSCs that self-renew and give rise to progenitors for life, ST-HSCs with less self-renewal capacity and MPPs lacking self-renewal potential but still bearing the capacity to differentiate into all lineages (Morrison et al., 1997; Morrison \& Weissman, 1994). The MPP cells can then commit to common lymphoid progenitors (CLP), expressing interleukin (IL)-7R $\alpha$, or common myeloid progenitors (CMP), lacking expression of Sca-1 and IL-7R $\alpha$ (Akashi et al., 2000; Kondo et al., 1997). These progenitor cells can then differentiate into all mature hematopoietic cells. As an alternative to the classical hematopoietic tree, Adolfsson et al. described the existence of lymphoid-primed multipotent progenitors (LMPPs) that can give rise to all lymphoid and myeloid cells except for erythrocytes and platelets (Adolfsson et al., 2005). This is one example of several suggested pathways differing from the "traditional" hematopoietic tree, and it is still under debate how lineage commitment is regulated from the HSC down to mature cells (Ema et al., 2014; Yamamoto et al., 2013).

A decade ago the signal lymphocytic activation molecules (SLAM) CD150 and CD48 were added to the repertoire of cell surface markers used to enrich for murine HSCs. It was shown by BrdU labeling and use of histone $2 \mathrm{~b}$ green fluorescent protein (H2B-GFP) transgenic mice, which both are used to assess cell cycling (Kanda et al., 1998), that Lin ${ }^{-S}$-a$1^{+} \mathrm{c}-\mathrm{kit}^{+} \mathrm{CD} 34^{-} \mathrm{FLT3}^{-} \mathrm{CD} 150^{+} \mathrm{CD} 48^{-}$harbor true dormant HSCs, with a predicted division rate of every 145 days (Wilson et al., 2008). Recently it was shown through transplantation that cells expressing homeobox B5 (HoxB5) defines a fraction of HSCs with long-term repopulation capacity (Chen et al., 2016). In addition to using cell surface markers, HSCs can be isolated based on their ability to efflux the fluorescent DNA-binding dye Hoechst 33342, creating a Hoechst ${ }^{\text {low }}$ population (side population, SP) (Goodell et al., 1996), as well as by their low binding of the dye Rhodamine-123 (Rho) (Li \& Johnson, 1992). However, to show the existence of self-renewing HSCs, transplantation experiments are the golden standard 
(Figure 2). LT-HSCs are defined as contributing to more than $1 \%$ circulating white blood cells 16 weeks or later after transplantation, and generating more than $1 \%$ myeloid and lymphoid progenitors (Dykstra et al., 2006; Ema et al., 2005; Frisch \& Calvi, 2014; Miller \& Eaves, 1997).

By enrichment of LT-HSCs it has been possible to identify subtypes more prone to myeloid or lymphoid differentiation (Challen et al., 2010). The myeloid-biased HSCs were shown to reside in the lower SP, being more quiescent and expressing higher levels of CD150 compared to lymphoid-biased HSCs. Upon aging it has been shown that the number of both mouse and human HSCs increases (Dykstra et al., 2011; Pang et al., 2011) but that the number of cells with long-term reconstitution capacity decreases (Chambers et al., 2007). Further, it was shown that the number of myeloid-biased HSCs is increased during aging (Challen et al., 2010; Dykstra et al., 2011), although aged HSCs have lower capacity to produce progeny and upon transplantation show less efficient homing to the BM and lower self-renewal potential (Dykstra et al., 2011). It has also been shown by the long-label retaining method with $\mathrm{H} 2 \mathrm{~B}-\mathrm{GFP}$ that HSCs gradually lose their regenerative potential as they progressively divide (Qiu et al., 2014). In a recent study HSCs were monitored with the same method and shown to divide symmetrically four times throughout adult life before entering dormancy (Bernitz et al., 2016), which indicates that HSCs have a cellular memory regulating the number of self-renewal divisions and by this their maintenance and density in the BM.

Although there are no major differences between mouse and human hematopoietic organs, it has been shown that the human and murine HSC enrichment markers differ slightly. The most important cell surface antigens for identification of human HSCs are expression of CD34 and lack of or weak expression of the progenitor markers CD38 and CD45RA (Bhatia et al., 1997b; Randall et al., 1996; Sutherland et al., 1989; Terstappen et al., 1991). The expression of CD34 on human HSCs stands in clear contrast to the CD34- mouse HSCs (Osawa et al., 1996). Human $\mathrm{CD} 34^{+} \mathrm{CD} 38^{-}$cells give rise to both myeloid and lymphoid cells for at least 8 weeks, while $\mathrm{CD} 34^{+} \mathrm{CD} 38^{+}$cells have short-term repopulating capacity (3 weeks) and give rise to mostly myeloid cells (Glimm et al., 2001). Another important antigen for both murine and human HSC isolation is c-kit (Briddell et al., 1992; Ikuta \& Weissman, 1992; Ogawa et al., 1991). Other discrepancies of human HSCs compared to mouse HSCs are the lack of a homolog to Sca-1 and that addition of SLAM markers to the antibody set do not contribute to HSC enrichment upon transplantation to immunodeficient mice (Larochelle et al., 2011). Recently, reconstruction of clonal dynamics of $\mathrm{CD} 34^{+} \mathrm{CD} 38^{-} \mathrm{CD} 45 \mathrm{RA}^{-} \mathrm{CD} 90^{+}$ HSCs estimated the number of human HSCs to be in the range of 50,000-200,000 in total in a healthy adult man (Lee-Six et al., 2018). 


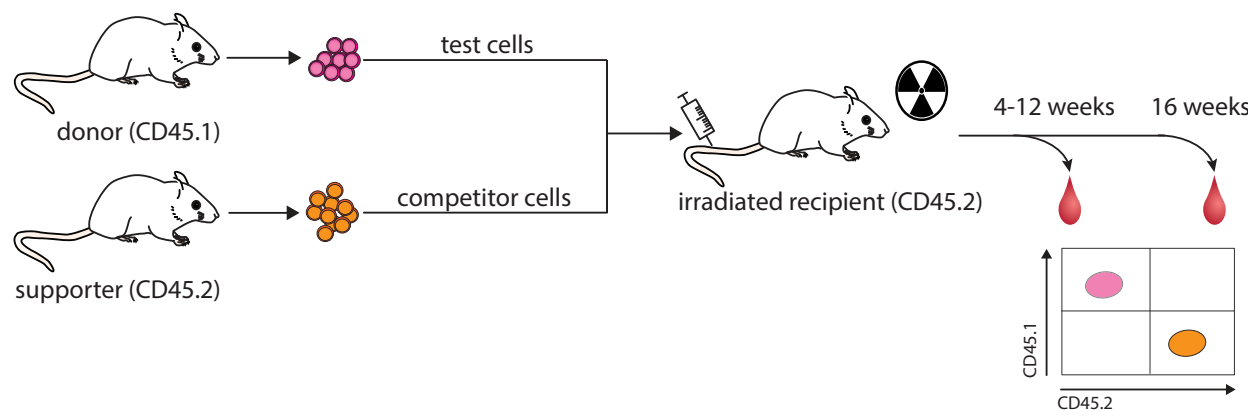

Figure 2. Competitive repopulation assay. Hematopoietic stem cells (HSCs) with unknown characteristics (test cells) are transplanted together with competitor cells from congenic mice into lethally irradiated recipients. The outcome is assessed by flow cytometry analysis of peripheral blood. Staining for the different forms of CD45 makes it possible to distinguish between donor cells (CD45.1; pink) and competitor cells (CD45.2; orange). Long-term (LT)-HSCs give rise to multilineage reconstitution later than 16 weeks post-transplant, while earlier readouts at 4-12 weeks demonstrate the activity of less primitive short-term (ST)-HSCs.

\section{Hematopoietic cytokines}

Proliferation and differentiation of mature hematopoietic cells are regulated by cytokines and growth factors, such as erythropoietin (EPO) for erythrocytes, granulocyte colonystimulating factor (G-CSF) for granulocytes and macrophage colony-stimulating factor (MCSF) for macrophages, while multipotent progenitors are dependent on a cocktail of cytokines like granulocyte-macrophage colony-stimulating factor (GM-CSF), stem cell factor (SCF), thrombopoietin (TPO), Flt3-ligand (FL) and interleukins (ILs). For murine HSCs the regulatory role of several cytokines has been investigated, including SCF, TPO, IL-6 and FL.

The RTK c-kit is highly expressed on HSCs (Ikuta \& Weissman, 1992), which upon binding of SCF gets phosphorylated and induces signaling pathways including Ras/MAPK and JAK/STAT pathways promoting proliferation, while phosphatidylinositide 3-kinase (PI3K)/AKT supports survival and inhibits apoptosis (Reber et al., 2006). TPO binds to its receptor c-Mpl, bringing its two domains closer and enabling binding of JAK2 for subsequent tyrosine phosphorylation and activation of STATs, PI3K and MAPK that promotes cell survival and proliferation (Kaushansky, 2005). Both SCF as well as TPO have been shown to maintain quiescent HSCs in steady state hematopoiesis (Thoren et al., 2008; Yoshihara et al., 2007). Mice with partial or complete lack of functional c-kit showed a severe reduction of progenitor cells and revealed an important role of c-kit in reconstituting peripheral blood and BM of irradiated mice post-transplantation (Sharma et al., 2007; Waskow \& Rodewald, 2002). TPO has been suggested to be an important regulator of HSC numbers and expansion (Fox et al., 2002; Kimura et al., 1998; Solar et al., 1998), and knock-out mice for Tpo or $c-m p l$, the receptor for Tpo, showed fewer HSCs in the BM, while $c$-mpl-deficient cells also showed dramatic reduction of progenitor cells as well as long-term repopulating HSCs upon serial transplantation. This indicates both a role in steady-state maintenance as well as in promoting self-renewal and expansion of HSCs in the BM following transplantation. 
IL-6, one of several interleukins regulating different hematopoietic cells, has just as SCF been shown to be an early acting lineage-non-specific factor for hematopoietic cells (Ogawa, 1993). IL-6 binds to the IL-6R, which together with the IL-6 signal transducer glycoprotein 130 (gp130) activates signaling pathways including JAK/STAT, MAPK and PI3K/AKT regulating proliferation, differentiation and survival (Heinrich et al., 2003; Mihara et al., 2012). IL-6 was shown in combination with SCF or SCF and IL-3 to enhance colony formation from LSK cells (Okada et al., 1992), and in combination with SCF and FL to expand murine HSCs in short-term cultures (Audet et al., 2001). Furthermore, primitive progenitor cells and HSCs from $\mathrm{Il}-6$ deficient mice have an impaired ability to form colonies and to maintain long-term hematopoiesis upon transplantation, respectively (Bernad et al., 1994), suggesting a regulatory role for IL-6 in HSCs. FL has been shown to in combination with SCF and IL-6 (Oostendorp et al., 2000) or SCF and IL-3 (Miller \& Eaves, 1997) stimulate expansion of murine BM stem cells in short-term cultures, but its role in regulating primitive HSCs was later outruled as studies have found that the Flt3-receptor is not expressed on LT-HSCs (Adolfsson et al., 2001; Christensen \& Weissman, 2001).

\section{In vitro expansion of $H S C S$}

Transplantation of HSCs is a procedure where the patient can receive stem cells from himself (autologous) or from a donor (allogeneic) (Wilson et al., 2008). Hematopoietic stem cell transplantation (HSCT) was founded more than 50 years ago by E. Donnall Thomas who treated patients with radiation and chemotherapy followed by infusion of donor BM cells (Thomas et al., 1957). By refinement of the method and discovery of factors to match donor and recipient, HSCT is today a standard of care for hematological malignancies, including leukemia where the patient has become resistant to chemotherapy. HSCs can be collected from the BM, cord blood or from peripheral blood by G-CSF induced mobilization of BM HSCs (Petit et al., 2002). The major limiting factor for a successful transplant and engraftment of the BM is a shortage of donor cells, especially when it comes to cord blood where the number of HSCs is limited and insufficient for transplantation of adult patients (Ballen et al., 2013). Therefore in vitro expansion of HSCs is promising to increase positive outcomes in the clinic.

As mentioned above, the importance for maintaining HSCs in vitro is dependent on, among others, cytokines, and therefore cytokines were among the first to be tested singly, or in combination, for their effect on in vitro expansion of murine HSCs (Shpall et al., 2002). Overall, cytokines in different combinations, including SCF, TPO, IL-6 and FL, can maintain human HSCs and their progenitors in ex vivo culture (Bhatia et al., 1997a; Conneally et al., 1997; Gammaitoni et al., 2003). However, in vitro expansion of short-term reconstituting progenitors often takes over at the expense of long-term reconstituting HSCs (Williams, 1993), pointing to the need for additional factors for successful expansion of LT-HSCs.

Mimicking the in vivo condition found in the BM seems logical for this purpose. Several strategies have been employed to maintain primitive HSC self-renewal potential and expand 
HSCs for transplantation, for instance to culture HSCs either on fibronectin-coated polymeric biomaterials (Feng et al., 2006), in stroma-conditioned medium or to co-culture with mesenchymal stromal cells (MSCs) together with growth factors, so-called Dexter culture (de Lima et al., 2012; Dexter, 1984; Ito et al., 2015; Jing et al., 2010; Robinson et al., 2006; Walenda et al., 2010). Besides secreting cytokines, the stromal cells provide important cellcell contact with HSCs through ligand-receptor interactions as well as integrins and the extracellular matrix (Discher et al., 2009; Gattazzo et al., 2014; Morrison \& Scadden, 2014). Especially Notch signaling supports HSCs, and its ligands Delta1 and Jagged1 have been shown to improve culture conditions for cord blood and adult HSC expansion (Delaney et al., 2010; Kertesz et al., 2006; Suzuki et al., 2006).

Recently, small synthetic molecules have been used in the hunt for conditions optimizing HSC expansion. StemRegenin 1 (SR-1), a purine derivative that antagonizes the aryl hydrocarbon receptor (AHR), was found to promote a 50-fold in vitro expansion of human cord blood CD $34^{+}$cells and a 17 -fold increase of LT-HSCs engrafting immunodeficient mice (Boitano et al., 2010). In a clinical study with patients, SR-1 demonstrated a remarkable recovery of blood cells and better engraftment upon transplantation compared to patients receiving non-expanded CD34 ${ }^{+}$cord blood cells (Wagner et al., 2016). UM171 is another small chemical, a pyrimidoindole derivative, that in an AHR-independent manner contributes to better expansion of human $\mathrm{CD} 34^{+} \mathrm{CD} 45 \mathrm{RA}$ cells from mobilized peripheral blood than SR1 (Fares et al., 2014).

Hence, since the vast majority of the proliferating cells lose their regenerative potential within a few days of culture, all of the approaches described above have in common that normally only short-term and progenitor engraftment, and not long-term engraftment, is achieved.

\section{Bone marrow niches}

Improving our understanding of the HSC-intrinsic and BM-dependent mechanisms regulating HSC self-renewal in vivo are most likely essential for designing the optimal platform for in vitro HSC expansion for therapeutic applications. Thus, the strive to identify microenvironment components in which HSCs reside would allow for the identification of factors essential to maintain and expand HSCs for transplantation. The concept of a microenvironment in the BM controlling the balance between quiescence and differentiation of hematopoietic stem and progenitor cell (HSPC) was proposed 40 years ago by Ray Schofield, who recognized that cells from the BM reconstituted blood formation of irradiated mice better than CFU-S cells and drew the conclusion that a niche within the BM preserves the reconstitution ability of HSCs (Schofield, 1978).

It is evident that the BM niche is crucial for HSC regulation and maintenance, but it has until recent years been unknown why the niche is located in specific tissues such as the kidney in fish and BM in mammals (Martinez-Agosto et al., 2007). In a study by Kapp et al. the HSPC niche in zebrafish was examined on the assumption that niches in terrestrial 
animals would have evolved at sites protecting the HSPCs from ionizing radiation while the water would have protected aquatic animals. They revealed that melanocytes are forming a protective umbrella over the HSPCs in different species of fish and frogs and by this protects the cells from UV light and its damaging effect on DNA as well as its ability to induce cell death (Kapp et al., 2018). This finding could explain why HSCs are found in the BM of terrestrial animal since the bone creates complete protection from UV irradiation.

The anatomical and structural association of stem cells, their progeny, and niche cells remains elusive, which is partly due to the lack of rigorously identified HSCs markers as well as the complex interactions between cells and factors. Furthermore, since experiments usually impair one type of niche cell, genetically or pharmacologically, to analyze the change in HSC phenotype, it compromises the ability to study HSC microenvironments in vivo. Live imaging of HSCs in the marrow cavity or functional studies in murine models have led to the discovery of numerous cellular constituents of the niche. These niche cells participate in regulation of HSC function and maintenance through both direct cell-cell interaction as well as by release of soluble factors, limiting cell replication-associated damage (Bakker \& Passegue, 2013). Recent studies indicate the existence of two BM niches, the endosteal and the perivascular niche (Figure 3 ).

\section{Endosteal niche}

The endosteal niche, the border between bone and BM of the trabecular (more porous bone) cavities, is coated with osteoblastic lineage cells (OBCs) that can differentiate to, among others, osteoprogenitors and osteoblasts (OBs). Bone forming cells were the first potential hematopoietic supporter cells identified through in vitro studies showing that OBs derived from human BM cells could support hematopoietic cells in culture (Taichman \& Emerson, 1994). This was followed by the use of transgenic mice where increased number of OBs led to increased number of HSPCs (Calvi et al., 2003; Zhang et al., 2003), providing experimental evidence for the niche hypothesis. Differentiating OBCs express several factors and adhesion molecules, including the osteoblastic ligand autocrine angiopoietin-1 (ANG1) and its receptor TIE2 on HSCs (Arai et al., 2004), stromal derived factor-1 (SDF-1 or chemokine (C-X-C motif) ligand 12 (CXCL12)) bound by its receptor C-X-C chemokine receptor type 4 (CXCR4) on HSCs (Jung et al., 2006) and TPO (Yoshihara et al., 2007). Furthermore, in a mouse model ablated for OBs, the Notch ligand Jagged-1 appeared to be involved in maintenance of LT-HSCs, since LT-HSCs in these mice showed reduced quiescence, as well as impaired engraftment and self-renewal capacity upon transplantation (Bowers et al., 2015). All these factors are likely to regulate HSC function by maintaining the stem cell pool and retaining HSCs close to the endosteal surface. Recently, the regulatory role of the endosteal niche has been questioned, since OBs were shown not to directly regulate HSC maintenance (Ding \& Morrison, 2013; Frenette et al., 2013; Greenbaum et al., 2013). Instead, deletion of SCF or CXCL2 in OBCs does not affect the HSC numbers, but rather reduces the number of B lymphoid progenitors (Ding \& Morrison, 2013; Greenbaum et al., 
2013), indicating the role of OBCs in lymphoid differentiation since these cells have been shown to secrete IL-7 (Wu et al., 2008).

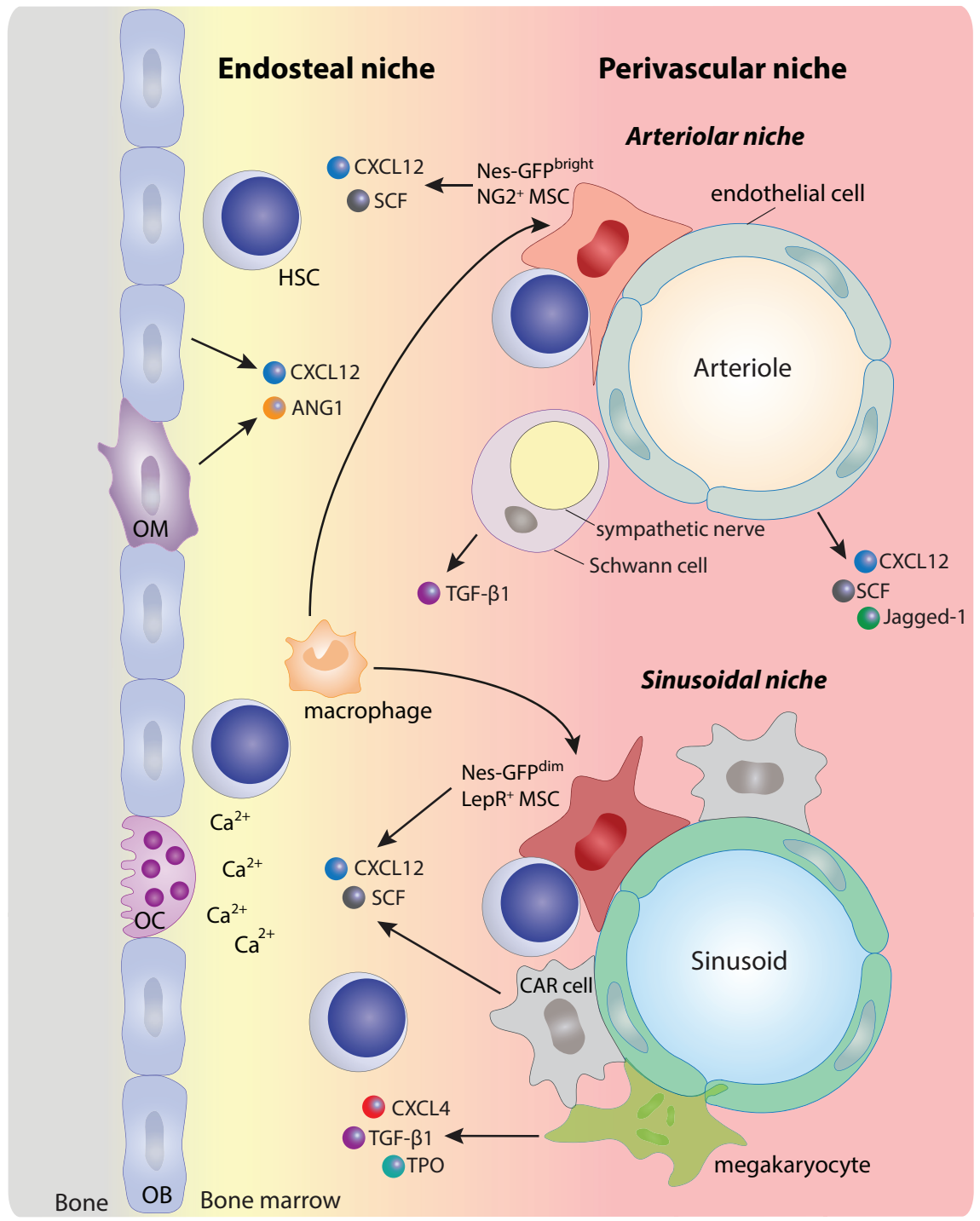

Figure 3. Endosteal and perivascular niches. Niches of the bone marrow regulate HSC maintenance through direct interaction or by soluble factors. The endosteal niche consists of osteoblasts (OB) and osteomacs (OM) and is remodeled by osteoclasts (OC). The perivascular niche consists of two subniches; the arteriolar niche with endothelial cells (ECs), sympathetic nerves, Schwann cells and neuron/glial antigen 2 (NG2) $^{+}$mesenchymal stem cells (MSC), and the sinusoidal niche with leptin receptor (LepR) ${ }^{+}$MSCs, CXCL12-abundant reticular (CAR) cells and megakaryocytes. Macrophages regulate HSC retention through crosstalk with Nestin $(\mathrm{Nes})^{+}$ cells, and osteoclasts release calcium $\left(\mathrm{Ca}^{2+}\right)$ upon bone turnover. Adapted with modifications from Emma Rörby (Rörby, 2014), with permission. 


\section{Perivascular niche}

The blood vessels in the BM called sinusoids, surrounded by perivascular MSCs, form another potential niche, the perivascular niche ( $\mathrm{K}$ iel \& M orrison, 2008). This niche regulates both self-renewal and formation of differentiated progenitors by soluble factors, cell interactions between the niche and HSC through factors like ANG1 and CXCL12, and physical parameters. The sinusoid is a type of smaller vein with walls of a single endothelial cell (EC) layer located between the bloodstream inside the sinusoids and the stromal microenvironment that surrounds the blood vessels, which permits cells to pass in and out of blood circulation ( $\mathrm{K}$ iel et al., 2005). Sinusoids build up the marrow vasculature and have been found to be enriched along the bone surface (Nombela-A rrieta et al., 2013). ECs express HSC-supportive factors such as SCF and CXCL12 that upon deletion lead to depletion of HSCs, indicating the importance of EC maintenance of HSCs (Ding \& M orrison, 2013; Ding et al., 2012b; Greenbaum et al., 2013). A recent study using a method for 3D-imaging of the hematopoietic niche, where autoflourescent cells are depleted from the tibia, showed that a certain fraction of LT-HSCs expressing HoxB 5 are located uniformly throughout the bone and nearly all are in close proximity to vascular endothelial (VE)-cadherin ${ }^{+} \mathrm{ECs}$ (Chen et al., 2016).

The MSCs wrapped around the sinusoids are in direct contact with the ECs and are believed to participate in the regulation of $\mathrm{HSC}$ homing and maintenance, by both direct interactions and by the release of soluble factors. The MSCS can be visualized by a Nestin (Nes)-GFP transgene (M endez-Ferrer et al., 2010) and detected by the expression of markers such as leptin receptor (LepR) (Zhou et al., 2014), and the pericyte marker neuron/glial antigen 2 (NG2) (K unisaki et al., 2013). Depending on the expression of LepR and NG2, there seem to be two M SC niches, the arteriolar and sinusoidal niche (for a more detailed description of the cells forming the niches, see Figure 3). The arteriolar/endosteal niche seems to maintain HSC quiescence through contact with arteriolar $\mathrm{NG}^{+} \mathrm{MSC}$, while the sinusoidal niche with $\mathrm{LepR}^{+}$cells would harbor more proliferating HSCs (K unisaki et al., 2013). However, a more recent study has questioned the study by Kunisaki et al (2013) and the role of $\mathrm{NG}^{+}$arteriolar MSCs in maintaining HSC quiescence (A car et al., 2015). In the study optical clearing was used, which enables deeper penetration of light compared to conventional immunofluorescent imaging of thin tissue sections and by this reveals more of the rare HSCs and their localization in the BM, showing that both quiescent and proliferating HSCs are located close to sinusoids and their $\mathrm{LepR}^{+} \mathrm{CXCL} 12^{+} \mathrm{MSC}$.

It is further suggested through live imaging of the skull that the osteoblastic niche maintains quiescent HSCs while the perivascular niche is more important for producing progenitor cells and for regulating homeostasis in the hematopoietic system rather than for forming a niche that preserves HSCs (Lo Celso et al., 2009). However, recently it was shown that the endosteal osteoblastic niche likely supports early lymphoid development while perivascular stromal cells express CXCL12 important for retention of HSCs in the BM (Ding \& Morrison, 2013). Furthermore, by immunofluorescent imaging of the $B M$ microenvironment, HSCs were detected in the proposed endosteal niche, but nearly $60 \%$ of 
the HSCs where shown to be directly associated with the vasculature (Kiel et al., 2005; Kunisaki et al., 2013). Thus, the BM vasculature seems to provide an important regulatory environment for maintaining HSC quiescence, as well as offering accommodation close to the bloodstream giving the HSCs quick access to enter or leave the BM. In summary, the identification of two separate niches, endosteal and perivascular, is most likely too simplistic and could be redefined as more advanced imaging techniques develop.

\section{Role of oxidative stress in HSCs}

It has been shown that a low amount of intracellular reactive oxygen species (ROS) is important for the maintenance of HSC. In a study where mouse BM cells were isolated related to intracellular ROS amount and transplanted into irradiated mice it was indicated that the cells with low intracellular ROS maintained their self-renewal potential at serial transplantation whereas cells with high amounts of ROS did not (Jang \& Sharkis, 2007). LTHSCs have been shown to preferentially use glycolysis to produce ATP (Ito \& Suda, 2014; Suda et al., 2011; Takubo et al., 2013), which has been linked to a hypoxic profile (Parmar et al., 2007; Simsek et al., 2010). In contrast, ST-HSCs and MPPs rely primarily on mitochondrial OXPHOS for ATP production (Takubo et al., 2013; Yu et al., 2013). The distinct metabolic program for LT-HSCs appears to play a critical role in maintaining their self-renewal capacity, since reduced mitochondrial respiration protects the cells from damage inflicted by ROS (Chen et al., 2008; Ito et al., 2004; Ito et al., 2006; Tothova et al., 2007). Furthermore, it has been shown that HSCs have low mitochondrial mass that increases upon differentiation concomitant with an elevation of ROS production (Rehman, 2010), and that murine HSCs and CMPs maintained low production of ROS that remained low upon differentiation to megakaryocyte/erythrocyte progenitors (MEPs) but increased markedly upon differentiation to granulocyte/macrophage progenitors (GMPs) (Shinohara et al., 2014). ROS at physiological levels is generated mainly by the mitochondria and secondarily by NAPDH oxidase (NOX) in the plasma membrane (Holmstrom \& Finkel, 2014; Jang \& Sharkis, 2007), while high ROS production can be derived from other sources such as cytochrome P450 in the endoplasmic reticulum (Urao \& Ushio-Fukai, 2013) and nitric oxide synthase in the cytosol (Figure 4) (Cau et al., 2012).

The major source of ROS production is the mitochondria and the electron transport chain (ETC) that generates superoxide anion radicals $\left(\mathrm{O}_{2}^{-}\right)$through single-electron leak at respiratory complexes I (NADH dehydrogenase) and III (cytochrome c reductase) of the OXPHOS pathway (Brand, 2010; Droge, 2002). Since the different oxygen species produced can damage DNA and cell functions, several antioxidant and enzyme defense systems have evolved in the cell, maintaining a cellular balance between ROS generation and clearance. There are five major types of primary intracellular antioxidant enzymes, which are cytosolic $\mathrm{Cu} / \mathrm{Zn}$-superoxide dismutase (Cu/Zn-SOD, SOD1), mitochondrial manganese superoxide dismutase (Mn-SOD, SOD2), catalase (CAT) in peroxisomes and the cytoplasm, glutathione peroxidase (GPx) that can be found in many compartments including mitochondria, and 


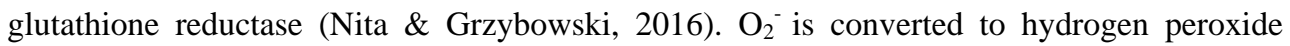
$\left(\mathrm{H}_{2} \mathrm{O}_{2}\right)$ by SOD1 or SOD2 (O rrenius et al., 2007). Subsequently the reactive peroxide can be converted either by $\mathrm{GPxS}$ to $2 \mathrm{H}_{2} \mathrm{O}$ with the antioxidant glutathione as electron donor, or by CA T into $\mathrm{H}_{2} \mathrm{O}$ and $\mathrm{O}_{2}$ (West \& $\mathrm{M}$ arnett, 2006). If these antioxidant systems are not efficient enough, $\mathrm{H}_{2} \mathrm{O}_{2}$ is rapidly reduced by $\mathrm{Fe}^{2+}$ or $\mathrm{Cu}^{2+}$ (Fenton reaction) to the most reactive form of oxygen, the hydroxyl radical ( $\cdot \mathrm{OH}$ ) (Droge, 2002), which may cause major damage of nucleic acids, proteins and membrane lipids and trigger development of cancers (Sallmyr et al., 2008).

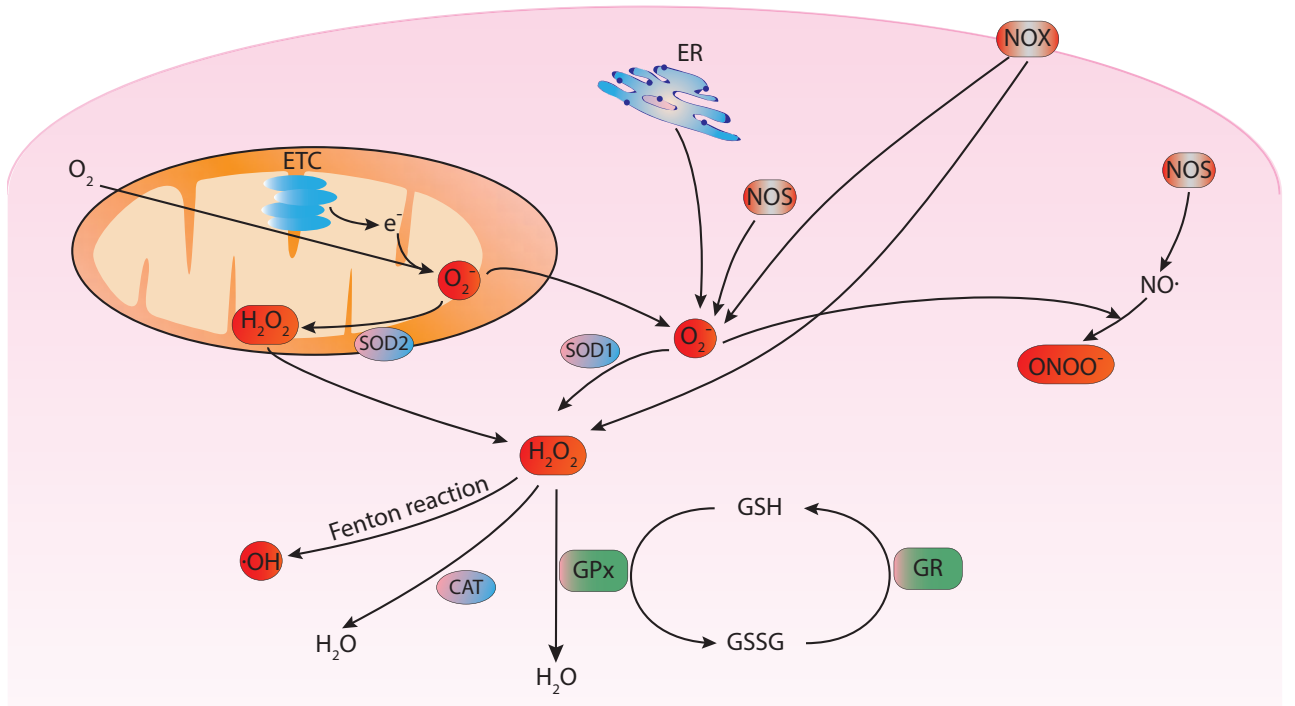

Figure 4. Schematic illustration of cellular maintenance of redox homeostasis. M itochondrial electron transport chain (ETC), NADPH oxidase (NOX), cytochrome P450 in the endoplasmic reticulum (ER) and nitrice oxide synthase (NOS) are intracellular sources of reactive oxygen species (ROS). Superoxide $\left(\mathrm{O}_{2}^{-}\right)$can rapidly be converted into hydrogen peroxide $\left(\mathrm{H}_{2} \mathrm{O}_{2}\right)$ by superoxide dismutases (SODs) or alternatively form peroxynitrite $\left(\mathrm{ONOO}^{-}\right)$through reaction with nitric oxide $(\mathrm{NO}) . \mathrm{H}_{2} \mathrm{O}_{2}$ can be converted to $\mathrm{H}_{2} \mathrm{O}$ by catalase (CAT) or glutathione peroxidase ( $\mathrm{GPX}$ ), which couple reduction of $\mathrm{H}_{2} \mathrm{O}_{2}$ with oxidation of glutathione (GSH). Oxidized glutathione (GSSG) is reduced by glutathione reductase (GR). U pon oxidative stress $\mathrm{H}_{2} \mathrm{O}_{2} \mathrm{Can}_{\text {be }}$ catalyzed to the hydroxyl radical $(\mathrm{OH})$ in the presence of $\mathrm{Fe}^{2+}$ or $\mathrm{Cu}^{2+}$ ions (Fenton reaction). 


\section{Resistance to oxidative stress}

Except for the antioxidants and enzymes mitigating intracellular ROS levels, HSCs possess several antioxidant systems to eliminate the intracellular ROS and minimize ROS induced damage. The ataxia telangiectasia mutated (Atm) gene maintains genomic stability by activating a cell cycle checkpoint upon DNA damage or oxidative stress, and HSCs from mice lacking ATM expression have been shown to suffer from increased levels of $\mathrm{H}_{2} \mathrm{O}_{2}$ (Ito et al., 2004). This impairs their lifespan and reconstitution capacity, and treatment of ATMdeficient mice with N-Acetyl-L-Cysteine (NAC), a precursor of cysteine that is the ratelimiting substrate for glutathione synthesis (Zafarullah et al., 2003), rescues the defects of HSC function, indicating the importance of ATM in reducing intracellular ROS levels to maintain the self-renewal capacity of HSCs. Furthermore, $\mathrm{H}_{2} \mathrm{O}_{2}$ elevation due to ATM deficiency in HSCs activates p38 MAPK, which triggers HSCs to exit from their quiescent state, and that has been shown to result in premature senescence or apoptosis (Ito et al., 2006; Wang et al., 2011a). Furthermore, p38 MAPK inhibition promotes HSC self-renewal but upon ROS exposure mediates cellular senescence via upregulation of p16 (Wang et al., 2011a). The major tumor suppressor gene, p53, is involved in regulation of HSC quiescence and selfrenewal (Liu et al., 2009), and has upon $\mathrm{H}_{2} \mathrm{O}_{2}$ accumulation been shown to deplete HSCs by inducing cell cycle arrest and apoptosis (Abbas et al., 2010), indicating that an appropriate level of p53 and $\mathrm{H}_{2} \mathrm{O}_{2}$ is essential for HSC maintenance.

Phosphatase and tensin homolog (PTEN)/PI3K/AKT/mammalian target of rapamycin (mTOR) signaling pathway is another pathway with a key role in cell proliferation and survival, where PI3K activates AKT to mediate further downstream signaling events, and is negatively regulated by PTEN. While Aktl/Akt2 double-deficient mice showed defective differentiation of HSCs due to decreased ROS levels that could be restored by an increase in ROS production (Juntilla et al., 2010), constitutively active AKT accelerates proliferation with concomitant increased $\mathrm{H}_{2} \mathrm{O}_{2}$ levels and depletion of HSC (Kharas et al., 2010). Furthermore, since PTEN is negatively regulated by $\mathrm{H}_{2} \mathrm{O}_{2}$, inhibition of PTEN by increased levels of ROS leads to activation of AKT and increased cell proliferation (Leslie et al., 2003), altogether demonstrating the importance of appropriate AKT levels for normal HSC function.

Forkhead homeobox type $\mathrm{O}$ (FoxO) transcription factors belong to the forkhead family, and are involved in diverse processes including regulation of quiescence, stress resistance and apoptosis. FoxO proteins are negatively regulated by PI3K and AKT, which through phosphorylation of FoxO cause its translocation out of the nucleus, leading to loss of HSC quiescence (Brunet et al., 1999). FoxO1, FoxO3a and FoxO4 are also critical mediators of cellular response to oxidative stress by redox regulation of HSCs, and conditional knockout of Foxol, Foxo3a and/or Foxo4 indicates that members of the FoxO subfamily play an important role in the protection of HSCs from oxidative stress by regulating the amount of intracellular ROS and maintaining the HSCs (Tothova et al., 2007). FoxO3a has been shown to be essential for HSC function since deletion of Foxo3a in HSCs leads to increased $\mathrm{H}_{2} \mathrm{O}_{2}$ levels and downregulation of antioxidant enzymes CAT and SOD2 (Miyamoto et al., 2007; Yalcin et al., 2008), resulting in defective maintenance of HSC quiescence, thus indicating a 
pivotal role for FoxO3a in maintenance of HSC self-renewal and stress resistance by negative regulation of proliferation.

Nuclear factor erythroid-2-related factor 2 (Nrf2) is a transcription factor involved in activation of antioxidant response elements-regulated antioxidant genes in response to oxidative stress (Itoh et al., 1999). Under physiological conditions, Nrf2 resides in the cytoplasm where it associates with an inhibitory protein, Kelch-like ECH-associated protein-1 (KEAP1), leading to Nrf2 ubiquitination and degradation (Furukawa \& Xiong, 2005). Keap1 possesses cysteines that act as redox sensors (Dinkova-Kostova et al., 2002; Zhang \& Hannink, 2003) and that upon oxidation by ROS results in the dissociation of Nrf2 from KEAP1, allowing Nrf2 stabilization and its translocation into the nucleus. In the nucleus Nrf2 activates ARE-dependent transcription of target genes coding for antioxidants and factors involved in processes regulating glutathione synthesis and ROS homeostasis (Itoh et al., 1997).

\section{Hypoxia and bone marrow niches}

Hypoxia is now recognized as an important regulatory niche factor of HSCs and the niches where HSCs reside were recently demonstrated to be hypoxic (Harrison et al., 2002; Nombela-Arrieta et al., 2013; Spencer et al., 2014). This is in agreement with findings that HSCs possess a hypoxic profile (Parmar et al., 2007; Simsek et al., 2010). The question is why HSCs reside in hypoxic niches, and how the low oxygen level affects the cells.

The BM environment was initially proposed to be aligned as a hypoxia-gradient, where the HSCs reside in the most hypoxic regions in close proximity to the endosteal surface of the osteoblastic niche, while more committed progenitors occupy the regions that have higher oxygen content (sinusoids in the vascular niche) (Figure 5A) (Parmar et al., 2007; Suda et al., 2011). A range of methods has been used to define the oxygen level in the BM and to prove the existence of a hypoxic niche: mathematical modeling (Chow et al., 2001), physiological measurement of the partial pressure of oxygen in healthy human adults (Harrison et al., 2002), and direct measurements of oxygen concentration in living animals with oxygen electrodes (Ceradini et al., 2004) or two-photon phosphorescence lifetime microscopy (Spencer et al., 2014).

Indirect assessment of intracellular oxygenation of cells by measurement of hypoxia inducible factor (HIF)-1 $\alpha$ or HIF target gene messenger-RNAs (mRNAs) (Simsek et al., 2010; Takubo et al., 2010), and staining with the hypoxic marker pimonidazole (Parmar et al., 2007), which binds protein thiol groups on cells at oxygen levels below 1.3\% (Levesque et al., 2007) are other methods to elucidate the existence of the hypoxic niche. Parmar et al. tested the hypothesis that HSCs are located in hypoxic areas with lower blood perfusion by injecting mice with the fluorescent dye Hoechst 33342 (Parmar et al., 2007), which would result in less brightly fluorescent cells due to their distance from blood supply that lead to lower dye exposure. Upon transplantation to mice, the population of cells with the lowest Hoechst fluorescence, believed to be hypoxic, contained the highest amount of LT-HSCs. This led to 
the conclusion that the level of oxygen in the BM was below $1 \%$ in the hypoxic endosteal niches, where slow-cycling cells were believed to reside, and $6 \%$ close to the sinusoids, where fast-cycling cells would reside (Cipolleschi et al., 1993; Eliasson \& Jönsson, 2010; Parmar et al., 2007).

Based on such studies the oxygen levels in most cell types of the body appear to range between 2-9\% (Simon \& Keith, 2008). In vitro studies also indicate that hypoxia can maintain the self-renewal capacity of HSCs (Cipolleschi et al., 1993; Ivanovic et al., 2004). Furthermore, several studies have shown that hypoxia favors a slow turnover of HSCs and sustains survival by promoting their quiescence (Eliasson et al., 2010; Hermitte et al., 2006; Shima et al., 2010), as well as being involved in regulation of glucose metabolism to avoid excessive mitochondrial oxidative phosphorylation (OXPHOS) and reactive oxygen species (ROS) production (Suda et al., 2011), which would otherwise induce cycling and exhaustion of HSCs (Ito et al., 2006; Ito \& Suda, 2014).

However, with time the idea of a hypoxic gradient has been questioned. A recent study drew the conclusion that irrespective of their localization in the BM, HSCs maintain a hypoxic profile, and the hypoxic status of HSCs may to a certain extent be regulated by cellspecific mechanisms and not by low oxygen level in the microenvironment (Nombela-Arrieta et al., 2013). By three-dimensional imaging visualizing whole longitudinal slices of murine femoral bones, the endosteal niche was shown to be well vascularized and by strong retention of pimonidazole and expression of HIF-1 $\alpha$, HSPCs displayed a hypoxic profile regardless of their localization in the BM (Figure 5B). Thus, the hypoxic profile of HSCs may be defined by intrinsic metabolic differences rather than by a hypoxic microenvironment.

A

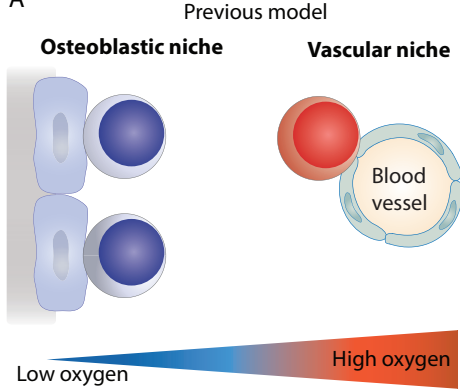

B

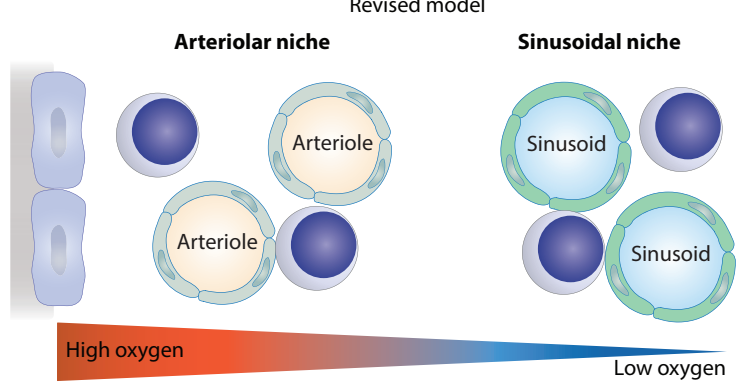

Figure 5. Hypoxia niche models for hematopoietic stem and progenitor cells. (A) The previous model for a hypoxic niche proposed that hypoxic and quiescent hematopoietic stem cells (HSCs) reside in poorly perfused endosteal regions with lowest oxygen levels, distant from oxygen-rich blood vessels harboring oxygenated and proliferating HSCs. (B) The revised model shows a well vascularized niche and exhibits an opposite oxygen gradient with highest oxygen level in arteriole-rich endosteal regions and the lowest in deeper areas of the bone marrow (BM). Hematopoietic stem and progenitor cells (HSPCs) and primitive progenitor cells reside in both arteriolar and sinusoidal niches and display similar hypoxic profile irrespectively of their positioning in different $\mathrm{BM}$ areas. Blue cells depict a hypoxic state, and red cells depict a normoxic state. 
Furthermore, in a recent publication the oxygen concentration was measured directly in the skull of live mice by the use of two-photon microscopy and a phosphorescent probe highly sensitive to local oxygen concentration, for the first time providing an accurate picture of oxygen distribution in the BM (Spencer et al., 2014). The oxygen level was low throughout the BM (1-4\%) with the highest oxygen tensions found in endosteal zones and a gradual decrease towards the central regions of the BM, which was explained by the direction of blood flow from the arterioles in the endosteal areas, carrying oxygenated blood, to the sinusoids in the more central parts of the BM where the blood rapidly gets depleted of oxygen.

Another study has shown that arteries are less permeable compared to sinusoids (Itkin et al., 2016), maintaining HSPCs in a metabolically quiescent state indicated by low ROS production, while more-permeable sinusoids sustain activated HSPCs with high ROS production. This indicates that arteries are creating an environment for the HSCs supporting lower ROS production, independent of its higher oxygen tension. If ignoring the metabolic state of the HSPCs, the HSCs were shown to localize randomly in the BM niches, confirming the results shown by Nombela-Arrieta and colleagues (Nombela-Arrieta et al., 2013).

Overall, the knowledge gained so far supports a complex model of hypoxic niches, turning evidence from quiescent HSCs residing in hypoxic osteoblastic niches to quiescent HSPCs not necessarily residing in the lower end of the oxygen gradient in the BM but in arteriolar and sinusoidal regions.

\section{Hypoxia-inducible factors (HIFs)}

The major regulator of the cellular response to hypoxia is the transcription factor HIF-1, which was discovered nearly three decades ago by the identification of hypoxia response elements (HREs) in the gene coding for EPO, which is induced by hypoxia (Goldberg et al., 1988; Semenza et al., 1991). HIF-1 is a heterodimer consisting of a $120 \mathrm{kDa}$ subunit HIF-1 $\alpha$ and a constitutively expressed HIF-1 $\beta$ subunit (aryl hydrocarbon receptor nuclear translocator (ARNT)) (Kallio et al., 1997; Wang et al., 1995). The HIF- $\alpha$ family has three members, HIF$1 \alpha$, HIF- $2 \alpha$ and HIF-3 $\alpha$ that are regulated by the tissue oxygen level. HIF- $2 \alpha$ shares $48 \%$ amino acid sequence identity of HIF- $1 \alpha$ as well as several of its hypoxic target genes (Hu et al., 2003), while less is known of HIF-3 $\alpha$ except that it binds to HREs and that one of its splice variants can through dimerization with HIF-1 $\alpha$ inhibit its transcriptional activity (Makino et al., 2001). HIF-1 $\alpha$ is ubiquitously expressed, while HIF-2 $\alpha$ has a more restricted expression in kidney, liver, brain, intestine, lung and vascular ECs (Wiesener et al., 2003).

HIF- $\alpha$ and HIF- $\beta$ subunits belong to the family of basic helix-loop-helix PER-ARNT-SIM (bHLH-PAS) domain-containing transcription factors, where the two domains bHLH and PAS have been shown to be important for DNA binding and dimerization (Wang et al., 1995). HIF-1 $\alpha$ also contains two transactivation domains (TADs), one in the N-terminal (N-TAD) and one in the C-terminal (C-TAD), which are responsible for HIF-1 $\alpha$ transcriptional activity (Li et al., 1996). C-TAD interacts with co-activators like CBP/p300, which promotes expression of HIF-1 $\alpha$ target genes (Ebert \& Bunn, 1998; Ema et al., 1999), partly by their role 
in stabilizing the transcription initiation complex containing RNA polymerase II, and partly by their histone acetyl-transferase activity that gives polymerase access to DNA within the chromatin for activation of RNA transcription. N-TAD has through HIF-1 $\alpha$ and HIF-2 $\alpha$ mutations been shown to confer target gene specificity (Hu et al., 2007). Furthermore, the HIF- $\alpha$ subunits have an oxygen-dependent degradation domain (ODDD) that mediates protein stability and is regulated by oxygen via post-translational modifications (Figure 6) (Bruick \& McKnight, 2001).

\section{Post-translational modifications}

HIF-1 $\alpha$ stability is regulated by several post-translational modifications such as ubiquitination, acetylation, phosphorylation, and SUMOylation (Koyasu et al., 2018). Furthermore, oxygen levels regulate HIF-1 $\alpha$ by hydroxylation. At oxygen levels above 5\% two prolines ( $\mathrm{Pro}^{402}$ and $\mathrm{Pro}^{564}$ ) in the ODDD and N-TAD of HIF-1 $\alpha$ are hydroxylated (Jiang et al., 1996) by the prolyl hydroxylase domain (PHD) proteins PHD1, PHD2 and PHD3 (Chowdhury et al., 2009; Kaelin \& Ratcliffe, 2008). PHDs belong to the $\alpha$-ketoglutarate ( $\alpha$ $\mathrm{KG}$ )-dependent dioxygenase family, and are oxygen-dependent for their functionality since PHD inserts one oxygen atom in HIF- $\alpha$ and the other in its substrate $\alpha-\mathrm{KG}$ upon proline hydroxylation.

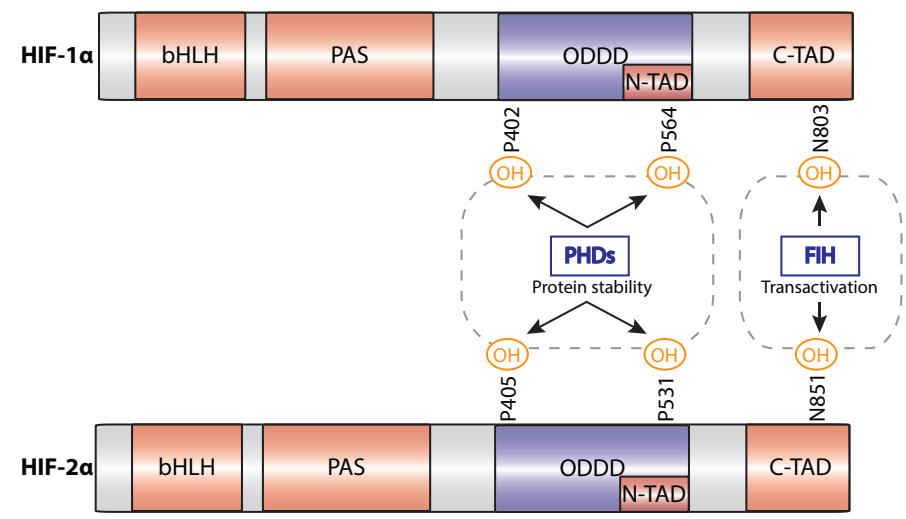

Figure 6. Domain structure of hypoxia-inducible factor $1 \alpha$ and hypoxia inducible factor $2 \alpha$. Schematic diagram of the primary structure and some major hydroxylated $(\mathrm{OH})$ amino acid residues of the hypoxiainducible factor $1 \alpha$ (HIF-1 $\alpha$ ) and HIF-2 $\alpha$. Gene symbols in red and blue depict positive and negative regulators of the $\alpha$-subunit, respectively. bHLH, basic helix-loop-helix; C-TAD, C-terminal transactivation domain; FIH, factor-inhibiting HIF; N, asparagine; N-TAD, N-terminal transactivation domain; ODDD, oxygen-dependent degradation domain; P, proline; PAS, PER-ARNT-SIM; PHD, prolyl hydroxylase domain. 
PHDs have been shown to have the potential to regulate the levels of HIF-1 $\alpha$ in cultured cells (Bruick \& McKnight, 2001), of which PHD2 has been proposed to be the most important oxygen sensor and regulator of HIF-1 $\alpha$ in normal mammalian cells (Berra et al., 2003). This proline hydroxylation in turn leads to binding of the ubiquitin ligase von HippelLindau (VHL) tumor suppressor protein, inducing proteasomal degradation of HIF-1 $\alpha$ (Ivan et al., 2001; Jaakkola et al., 2001; Maxwell et al., 1999). This degradation process is very rapid upon reoxygenation since HIF- $1 \alpha$ has a half-life shorter than 5 minutes (Wang et al., 1995).

HIF-2 $\alpha$ is also degraded by PHDs and VHL, with the exception that the prolines being hydroxylated in the ODDD are Pro $^{405}$ and Pro $^{531}$ (Furlow et al., 2009). HIF-1 $\alpha$ subunit modified by hydroxylated prolines and acetylated lysine is recognized by and favors interaction with VHL protein for subsequent ubiquitination and proteosomal degradation (Maxwell et al., 1999). Furthermore, asparaginyl hydroxylation of asparagine 803 (Asn ${ }^{803}$ ) within the C-TAD of HIF-1 $\alpha$ and Asn ${ }^{851}$ of HIF- $2 \alpha$ by the enzyme factor-inhibiting HIF (FIH), another $\alpha$-KG-dependent oxygenase that just as PHDs is oxygen-regulated, impairs the recruitment of $\mathrm{CBP} / \mathrm{p} 300$ co-activators and subsequently abrogates HIF-1 $\alpha$ activity through sterical hindrance of the interaction between HIF-1 $\alpha$ and CBP/p300 (Lando et al., 2002; Mahon et al., 2001).

When the oxygen level decreases below 5\%, the PHDs and FIH, for which oxygen is a limiting factor, are inhibited and HIF- $1 \alpha$ is stabilized due to abrogated hydroxylation and acetylation, and subsequently dimerizes with HIF- $1 \beta$ and the coactivators CBP/p300. This forms the transcriptionally active HIF-1 that can bind to HREs of its target genes in the nucleus (Figure 7). Hypoxia can also be mimicked by the addition of so-called hypoxiamimics in order to stabilize HIF-1 $\alpha$. Dimethyloxalylglycine (DMOG) easily permeates the cell and stabilizes HIF- $1 \alpha$ and HIF-2 $\alpha$ under normoxic conditions (Elvidge et al., 2006; Jaakkola et al., 2001). DMOG is a $\alpha-K G$ analogue and competitive inhibitor of both PHDs and FIH, leading to subsequent stabilization and transcriptional activation of HIFs. 


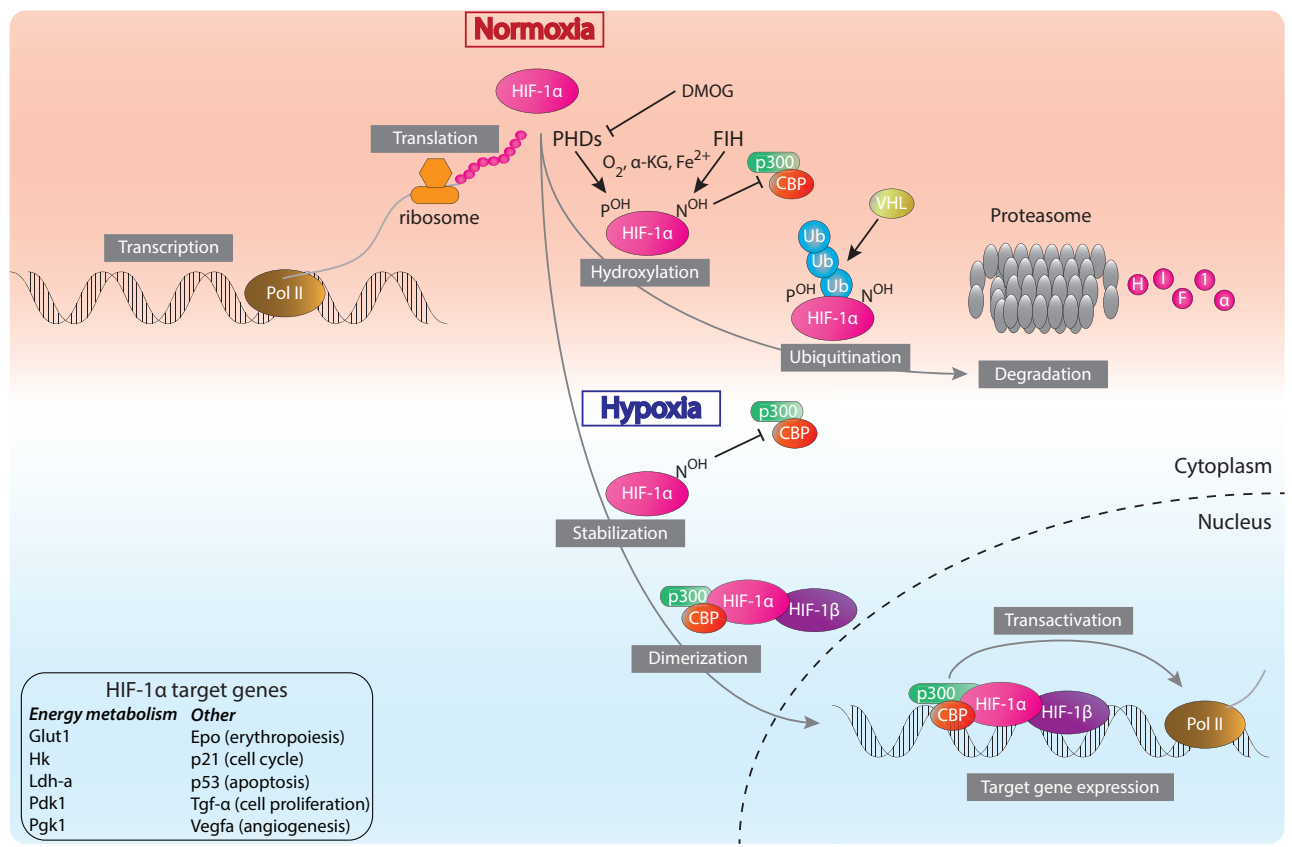

Figure 7. Oxygen-dependent regulatory mechanisms for hypoxia-inducible factor 1a. Hypoxia-inducible factor $1 \alpha(\mathrm{HIF}-1 \alpha)$ messenger-RNA (mRNA) is transcribed by RNA polymerase II (Pol II), followed by ribosomal translation to protein. In the presence of oxygen, active HIF hydroxylases, prolyl hydroxylase domains (PHDs) and factor-inhibiting HIF (FIH), downregulate and inactivate the HIF-1 $\alpha$ subunit. PHDs and FIH hydroxylate prolines and asparagine, which lead to von Hippel-Lindau (VHL)-dependent HIF-1 $\alpha$ degradation or inactivation of transcriptional activity of HIF- $1 \alpha$ by inhibiting recruitment of coactivators $\mathrm{CBP} / \mathrm{p} 300$, respectively. HIF hydroxylases are dependent on $\alpha$-ketoglutarate $(\alpha-\mathrm{KG})$, oxygen $\left(\mathrm{O}_{2}\right)$ and iron $\left(\mathrm{Fe}^{2+}\right)$, thus hydroxylases are inactive in hypoxia allowing HIF-1 $\alpha$ stabilization and formation of dimer with HIF$1 \beta$, which results in gene transcription of HIF-1 target genes. DMOG, dimethyloxalylglycine; EPO, erythropoietin; GLUT1, glucose transporter 1; HK, hexokinase; LDH-A, lactate dehydrogenase kinase A; N, asparagine; P, proline; PDK1, pyruvate dehydrogenase kinase 1; PGK1, phosphoglycerate kinase 1; TGF- $\alpha$, transforming growth factor $\alpha$; Ub, ubiquitination; VEGFA, vascular endothelial growth factor A.

\section{Hypoxic effects and hypoxia targets}

HIF-1 has been shown to regulate hundreds of genes in diverse biological pathways, and upregulated target genes have been shown to be involved in regulating pathways including angiogenesis (vascular endothelial growth factor A (VEGFA)), cell proliferation/survival (TGF- $\alpha$ ), apoptosis/cell cycle (p53 and p21), and erythropoiesis (EPO) (Ke \& Costa, 2006). Many of the most prominent and well-characterized target genes are involved in the regulation of oxygen supply and utilization. In order to acquire the most efficient use of oxygen by the cell, that is most adenosine triphosphate (ATP) and least ROS produced, HIFs activate genes central to a metabolic shift away from OXPHOS and towards glycolysis. Cells have a never-ending demand for energy, and the mitochondria produce energy in the OXPHOS pathway in the form of ATP. The OXPHOS pathway is a stepwise process in which a molecule of glucose in the cytosol is converted into pyruvate, which then can enter the 
mitochondria for further conversion in the tricarboxylic acid cycle (TCA) and electron transport chain (ETC) to finally produce carbon dioxide $\left(\mathrm{CO}_{2}\right), \mathrm{H}_{2} \mathrm{O}$ and energy (Figure 8) (Lodish et al., 2000).

At low oxygen levels energy metabolism in HSCs is switched from the mitochondria, since OXPHOS requires molecular oxygen for completion, to the cytosol and anaerobic glycolysis, also called the Pasteur effect (Miharada et al., 2011; Nombela-Arrieta et al., 2013; Parmar et al., 2007; Suda et al., 2011; Takubo et al., 2010). This metabolic response to hypoxia has been shown to be directly regulated by HIFs, which upregulate essentially all target genes encoding glycolytic enzymes (Benita et al., 2009). HIF-1 $\alpha$ and HIF-2 $\alpha$ share several target genes including VEGFA and glucose transporter 1 (GLUT1) (Hu et al., 2003), but while HIF-2 $\alpha$ activates genes that regulate ROS elimination including the antioxidant enzymes CAT and SOD1/-2 (Scortegagna et al., 2003), HIF-1 $\alpha$ has been shown to regulate transcription of genes encoding enzymes involved in the glycolytic pathway comprising hexokinase 2 (HK2), phosphoglycerate kinase 1 (PGK1) and lactate dehydrogenase (LDH-A) (Hu et al., 2003). In hypoxia the conversion of glucose to pyruvate generates 2 ATP molecules per glucose compared to the production of 36 ATP molecules per glucose by OXPHOS (Lodish et al., 2000).

Since glycolysis obviously is a relatively inefficient means for generating ATP it needs to be compensated for by increased glucose uptake and subsequent increase of lactate and ATP production (Simsek et al., 2010; Takubo et al., 2013). This is regulated by several HIF-1 target genes encoding proteins that enable a more efficient energy production in hypoxia comprising GLUTs, HKs, phosphofructokinase (PFK), PGK1, pyruvate dehydrogenase kinase 1 (PDK1) and LDH-A (Dengler et al., 2014). GLUT1 and -3 are involved in glucose uptake from the extracellular space into the cytosol, where the enzymes HK1 and -2 catalyze phosphorylation of glucose to glucose-6-phosphate. Glucose is thereafter degraded step by step by several enzymes, including PFK, until 1,3-bisphosphoglycerate reaches the enzyme PGK1 where the first ATPs are produced. In the last step of glycolysis ATPs and pyruvate are formed by pyruvate kinase before LDH-A converts pyruvate to lactate, the end product of anaerobic metabolism. PDK1 inhibits the enzyme pyruvate dehydrogenase (PDH), which when active allows pyruvate to enter the mitochondria and TCA cycle (Takubo et al., 2013) for further breakdown and ATP production.

Since many of the target genes of HIF-1 are expressed in HSCs, HIF-1 could be essential for regulating maintenance of HSCs (Takubo et al., 2010). Loss of LDH-A impairs the repopulation capacity of HSCs upon serial transplantation (Wang et al., 2014). Furthermore, HSCs in mice with deletion of $P d k 2$ and $P d k 4$ lost their quiescence upon transplantation (Takubo et al., 2013), and Pdkl-deficient HSCs showed significantly impaired engraftment (Halvarsson et al., 2017). Altogether, these studies indicate an important role for HIF-1 $\alpha$ and its targets in maintaining HSCs through metabolic regulation. 


\section{HIFs in HSC regulation}

HIF-1 has been shown by the use of mice lacking expression of the HIF-1 $\alpha$ subunit to be important for HSC quiescence and protection against various stress conditions, such as aging or BM transplantation (Takubo et al., 2010). Transplantation of HSCs from mice with conditional deletion of Hif-1 $\alpha$ showed that the recipient mice had more engrafted donor cells, but upon second transplantation the HSC pool was exhausted. However, conditional deletion of either Hif- $1 \alpha$ or Hif- $2 \alpha$ showed that they are dispensable for maintenance of HSCs upon steady-state in vivo (Guitart et al., 2013; Vukovic et al., 2016). Furthermore, conditional deletion of the HIF- $\alpha$ dimerization subunit Arnt or both Hif- $1 \alpha$ and Hif- $2 \alpha$ resulted in a subtle loss of HSC function by inducing apoptosis of LT-HSCs and minimal changes in the expression of glycolytic enzymes (Krock et al., 2015). According to these diverse results, it seems like the role of HIFs in HSCs are controversial, and could have different functions dependent on the circumstances.

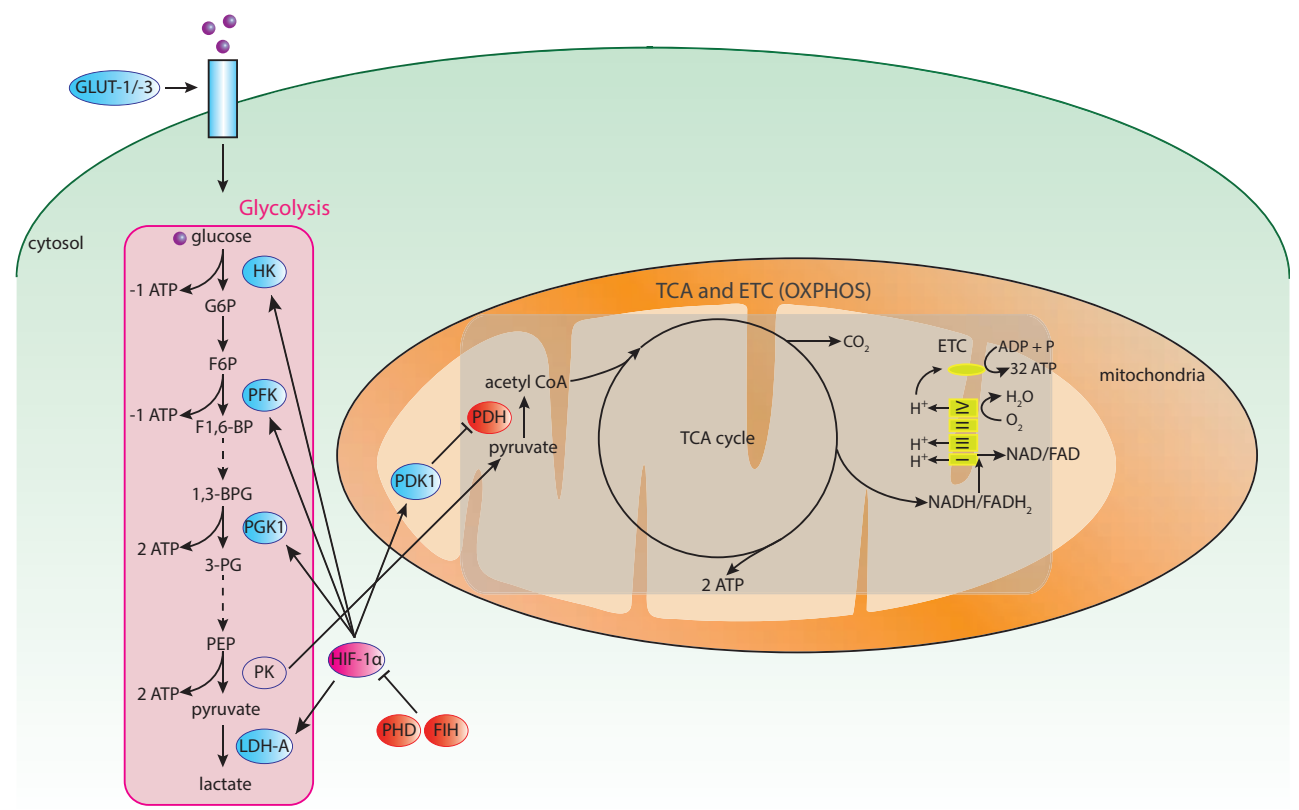

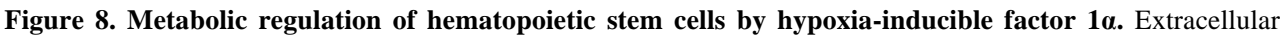
glucose is taken up by the cells by glucose transporter (GLUT)-1 and -3, where it can be subjected to glycolysis as response to hypoxia (pink area) or the tricarboxylic acid (TCA) cycle and electron transport chain (ETC, where oxidative phosphorylation (OXPHOS) takes place) as response to oxygenation (grey area). In hypoxia hypoxia-inducible factor (HIF)- $1 \alpha$ is not inhibited by prolyl hydroxylase domain (PHD) and factor-inhibiting HIF (FIH) proteins, and activates transcription of several genes involved in glycolysis, including hexokinase (HK), phosphofructokinase (PFK), phosphoglycerate kinase 1 (PGK1) and lactate dehydrogenase A (LDH-A). Furthermore, HIF-1 $\alpha$ activates pyruvate dehydrogenase kinase 1 (PDK1) that inhibits pyruvate dehydrogenase $(\mathrm{PDH})$ and thereby the uptake of pyruvate into the mitochondria. 1,3-BPG, 1,3-bisphosphoglyceric acid; 3-PG, 3-phosphoglyceric acid; ATP, adenosine triphosphate; F6P, fructose-6-phosphate; F1,6-BP, fructose-1,6bisphosphate; G6P, glucose-6-phosphate; PEP, phosphoenolpyruvate; PK, pyruvate kinase. Blue circles depict molecules that promote glycolysis, red circle molecules that inhibit glycolysis. 


\section{Alternative hypoxia-inducible pathways}

Not all hypoxic effects are regulated by HIF-1 $\alpha$, as other transcription factors have been shown to be regulated by hypoxia. The tumor suppressor p53 has been shown to be activated by hypoxia in an atypical way, where hypoxia induces p53 protein accumulation and apoptosis induction but no activation of some typical downstream target genes, including $p 21$ (Koumenis et al., 2001). Furthermore, BCL-2/adenovirus E1B 19kDa interacting protein 3 (Bnip3) was identified as a p53 target activated under hypoxia, which is different from those normally activated by DNA-damaging agents, and responsible for p53-mediated apoptosis following hypoxic stress (Fei et al., 2004). By genomic analysis of p53 in hypoxia it was shown that hypoxia-induced p53 primarily has repressive activity, repressing target genes involved in diverse signaling pathways including cell signaling, cell cycle control and differentiation (Hammond et al., 2006).

The c-Myc family contains genes coding for transcription factors involved in regulation of a wide variety of cellular processes of HSCs, such as proliferation and controlling the balance between self-renewal and differentiation (Wilson et al., 2004). Under hypoxic stress, c-Myc is inhibited by HIF-1 $\alpha$ leading to cell cycle arrest (Koshiji et al., 2004), while HIF-2 $\alpha$ has been shown to enhance c-Myc activity and thus inducing cell cycle (Gordan et al., 2007).

\section{Nuclear factor kappa B (NF- $\kappa \mathrm{B})$}

Two decades ago hypoxia was also shown to activate nuclear factor kappa B (NF-кB) (Koong et al., 1994), a transcription factor that exists in virtually all cell types and plays a critical role in cellular responses like inflammation, cell proliferation and survival (Pahl, 1999). NF-kB was first described as a nuclear factor necessary for immunoglobulin kappa light chain transcription in B cells, hence the name (Sen \& Baltimore, 1986). The NF- $\mathrm{B}$ family in mammals consists of the five subunits p65, RelB, c-Rel, NF- $\kappa B 1$ (p105/p50) and NF-kB2 (p100/p52), which can associate with each other to form homo- or heterodimeric complexes (Gilmore, 2006). These subunits share a conserved N-terminal Rel homology domain (RHD) that controls DNA binding, dimerization and interaction with inhibitory inhibitor of kappa B $(\mathrm{I} \kappa \mathrm{B})$. At homeostasis, NF- $\kappa \mathrm{B}$ preexists in the cytoplasm in an inactive form bound to an inhibitor, IкB (Hayden \& Ghosh, 2004). Both p50 and p52 are synthesized as longer precursor proteins, p105 and p100, which function as I $\kappa \mathrm{B}-$ like proteins and retain the NF- $\kappa \mathrm{B}$ subunits in the cytoplasm until they are processed, which is required before they can function as nuclear transcription factors. Since protein synthesis is not required upon response to a stimulus it allows the signal to be transmitted quickly.

Upon stimulation, several pathways have been described that lead to activation and regulation of NF- $\mathrm{KB}$ nuclear accumulation and DNA binding, which can be subdivided into canonical, non-canonical and atypical pathways (Figure 9). Briefly, the most well-studied pathway is the canonical, or classical, pathway of NF- $\kappa \mathrm{B}$ activation that is dependent on activation of transforming growth factor-B activating kinase (TAK1) and the IкB kinase (IKK) complex composed of the two subunits IKK $\alpha$ and IKK $\beta$, and the regulatory component 
IKK $\gamma$ (NEMO) (Hinz \& Scheidereit, 2014; Perkins, 2007). Phosphorylation of the IKK leads to subsequent phosphorylation of $\mathrm{I} \kappa \mathrm{B} \alpha$ at serine $32\left(\mathrm{Ser}^{32}\right)$ and $\mathrm{Ser}^{36}$, followed by ubiquitination and protesomal degradation (DiDonato et al., 1997). NF- $\kappa B$ is thereby released from IкB and enters the nucleus to activate transcription of target genes. The non-canonical, or alternative, pathway for NF- $\mathrm{KB}$ is activated by a relatively small number of factors, leading to IKK $\alpha$ phosphorylation and induction of the NF- $\kappa \mathrm{B}$ dimer composed of RelB and p52 subunits (Bonizzi \& Karin, 2004; Perkins, 2006). The atypical pathway is either IKK independent and acts directly on the IאBs, or utilizes IKK activity in a manner distinct from that found in canonical and non-canonical pathway (Perkins, 2007). A more thoroughly description of the pathways can be found in Figure 9.

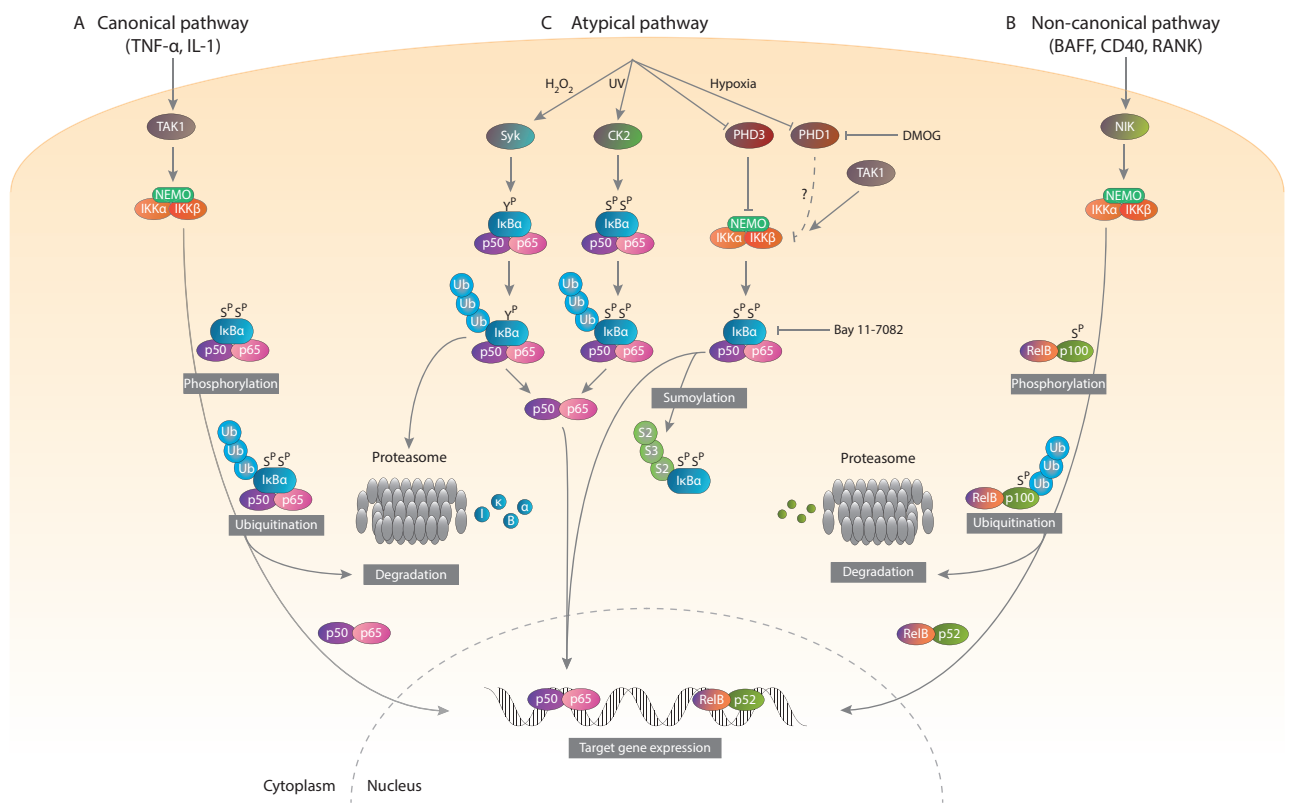

Figure 9. The canonical, non-canonical and atypical nuclear factor kappa B pathways. (A) The canonical nuclear factor kappa B (NF- $\kappa \mathrm{B})$ pathway can be activated by several stimuli, including tumor necrosis factor $\alpha$ (TNF- $\alpha$ ) and IL-1. Upon signaling via transforming growth factor-B activating kinase 1 (TAK1) inhibitor kappa B kinase $\beta$ (IKK $\beta$ ) is activated, leading to phosphorylation on serine (S) $S^{32}$ and $S^{36}$ of inhibitor kappa $B \alpha$ $(\mathrm{I} \kappa \mathrm{B} \alpha)$ and subsequent ubiquitination $(\mathrm{Ub})$ and proteosomal degradation. NF- $\kappa \mathrm{B}$ p50/p65 dimer thereafter translocate to the nucleus to activate target gene transcription. (B) The non-canonical pathway can be activated by B-cell activating factor (BAFF), receptor activator for nuclear factor kappa B (RANK) and CD40, which via $\mathrm{NF}-\kappa \mathrm{B}$-inducing kinase (NIK) activates IKK $\alpha$ of the IKK complex. IKK $\alpha$ in turn phosphorylates p100, leading to ubiquitination and proteosomal processing to p52, followed by nuclear translocation of the dimer RelB/p52. (C) The atypical pathway can be triggered by DNA damage in response to UV, inducing phosphorylation and degradation of I $\kappa \mathrm{B} \alpha$ by casein kinase II (CK2) (Kato et al., 2003), by oxidative stress $\left(\mathrm{H}_{2} \mathrm{O}_{2}\right)$ and Syk-mediated phosphorylation of $\mathrm{I} \kappa \mathrm{B} \alpha$ tyrosine $(\mathrm{Y})$, or by hypoxia through inhibition of prolyl hydroxylase domain (PHD) proteins, thus inducing IKK $\beta$ followed by phosphorylation of I $\kappa \mathrm{B} \alpha$ on $\mathrm{S}^{32}$ and $\mathrm{S}^{36}$ and release of $\mathrm{p} 50 / \mathrm{p} 65$. Upon hypoxia I $\kappa \mathrm{B} \alpha$ is not degraded, but by sumoylation (S2/S3) released from the p50/p65 dimer. Depicted are also the hypoxia-mimetic dimethyloxalylglycine (DMOG) and $\mathrm{I} \kappa \mathrm{B} \alpha$ phosphorylation inhibitor Bay 11-7082 (Pierce et al., 1997) that induce or reduce NF- $\mathrm{B}$ activity, respectively. 
In addition to many post-translational modifications involved in the regulation of the IKK complex and $\mathrm{I} \kappa \mathrm{B}$ proteins, the NF- $\mathrm{KB}$ proteins can directly be modified by phosphorylation, ubiquitination, SUMOylation and acetylation (Perkins, 2006). Phosphorylation of NF- $\kappa$ B subunits controls interactions with other factors, as well as stability, degradation and transcription activity of NF- $\mathrm{BB}$ dimers (Christian et al., 2016). Phosphorylation of $\mathrm{p} 65$ has been most thoroughly investigated in this context where the two most well-known and bestunderstood phosphorylation sites are $\operatorname{Ser}^{276}$ and $\operatorname{Ser}^{536}$ in the N-terminal and C-terminal TAD, respectively. Phosphorylation of the sites can occur through several kinases. Ser ${ }^{276}$ is characterized as a Protein kinase A (PKA) phosphorylation site, which in its inactive form is

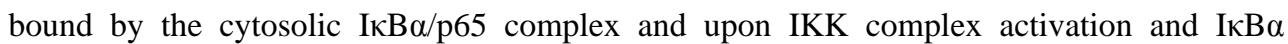
degradation liberates PKA for phosphorylation of p65 at $\operatorname{Ser}^{276}$ (Zhong et al., 1997). Upon phosphorylation a conformational change in p65 is triggered, which promotes its interaction with the coactivator $\mathrm{CBP} / \mathrm{p} 300$, thereby increasing p65 transcriptional activity and DNA binding (Zhong et al., 1998). Phosphorylation of $\operatorname{Ser}^{536}$ leads to enhanced transactivation through interaction with CBP/p300 and acetylation at lysine 310 (Lys ${ }^{310}$ ) (Chen et al., 2005), and phosphorylation of $\mathrm{Ser}^{536}$ is mediated by a number of kinases including IKKs (Buss et al., 2004; Sakurai et al., 1999).

\section{$N F-\kappa B$ in HSC regulation}

The role of NF- $\kappa B$ in regulation of HSCs has been studied, where conditional deletion of the p65 subunit resulted in decreased HSC number, impaired repopulation capacity and increased proliferation of HSPCs (Stein \& Baldwin, 2013). Furthermore, double-knockout mice for RelB/NF- $\mathrm{B} 2$ showed impaired HSPC engraftment and self-renewal capacity after transplantation into wildtype mice (Zhao et al., 2012). Transplantation of wildtype HSPCs into double-knockout mice, which showed reduced number of BM stromal and osteoblastic cells, induced wildtype-HSPCs to cycle more rapidly and showing aberrant differentiation with increased myeloid and decreased lymphoid lineages. Conclusively, NF- $\kappa \mathrm{B}$ activity seems to be required for HSC self-renewal and differentiation into myeloid and lymphoid lineages.

\section{Hypoxia and $N F-\kappa B$}

After the initial discovery of hypoxia-induced NF- $\kappa B$ activity (Koong et al., 1994) several studies followed, trying to elucidate the potential mechanism regulating hypoxia-induced NF$\kappa \mathrm{B}$ activity (Culver et al., 2010; Cummins et al., 2006; Oliver et al., 2009). Cummins et al. demonstrated that hypoxia activates $\mathrm{NF}-\kappa \mathrm{B}$ by induction of IKK $\beta$ followed by phosphorylation of $\mathrm{I} \kappa \mathrm{B} \alpha$ on $\mathrm{Ser}^{32}$ and $\mathrm{Ser}^{36}$ and release of NF- $\kappa \mathrm{B}$ (Cummins et al., 2006), which seems to be regulated by PHD1 (Cummins et al., 2006; Xie et al., 2014b). Furthermore, knockdown of p65 (Oliver et al., 2009) or inhibition or deletion of IKK (Culver et al., 2010; Melvin et al., 2011) abolished the effects seen by hypoxia-induced NF- $\kappa \mathrm{B}$ activation or 
caused impairment of hypoxia-induced phosphorylation of $\mathrm{I} \kappa \mathrm{B} \alpha$ on $\mathrm{Ser}^{32}$ and $\mathrm{Ser}^{36}$, respectively. This indicates that NF- $\kappa \mathrm{B}$ is activated by hypoxia mainly through the canonical pathway and that IKK has a crucial role in hypoxia-induced NF- $\kappa \mathrm{B}$ activation.

\section{Leukemia}

HSCs are challenged by both natural and man-made chemicals and radiation, as well as endogenous metabolic products in the form of ROS, which every day are estimated to cause thousands of damaging events to DNA (Kastan, 2008). In the form of cellular antioxidants, stress response and DNA repair mechanisms, the cell is able to repair most of the damage that otherwise could lead to different pathological conditions. However, over time on-going stress and age can cause DNA damage and subsequent mutations resulting in malignant transformation (Welch et al., 2012). The transformation from a normal cell into a leukemic cell is a multistep process, where mutations or deletions at chromosomal or epigenetic level either cause activation of oncogenes or inactivation of tumor suppressor genes. In the final cancer there could be several mutations present, but only a few contribute to the development of disease (Grove \& Vassiliou, 2014; Shlush \& Mitchell, 2015; Welch et al., 2012). This array of possible mutations makes the study of cancer and development of therapeutics a complicated research field.

Around 15 years ago the "two-hit" model was proposed by Gary Gilliland and James Griffin, explaining the onset of AML by disruptions at the molecular level leading to blocked differentiation and increased proliferation, the characteristic features of leukemia (Gilliland \& Griffin, 2002). In this model the origin of AML are mutations in two different classes of genes, of which none of the isolated classes can cause AML on its own. To class I belong mutations in genes encoding signal transduction pathways such as FLT3, C-KIT and BCR$A B L$ and that upon transformation confer a proliferative and survival advantage, while in class II are genes encoding TFs including CEBPA, PML-RAR $\alpha, R U N X 1$ and MLL rearrangements that upon mutation will inhibit differentiation and create accumulation of immature progenitors (Gilliland \& Griffin, 2002; Grove \& Vassiliou, 2014).

Newly discovered mutations have highlighted the presence of epigenetic modifications and revealed a more complex picture of AML. Thus, combinations of class I and II mutations in a synergistic manner seem to cooperate to induce epigenetic and transcriptional programming effects in favor of leukemic development (Shih et al., 2015). There are more than 70 genes identified as associated with leukemias, and in blood from individuals without apparent hematological malignancies some of the most frequently mutated somatic genes, identified by whole-exome sequencing, are DNMT3A, TET2 and ASXL1 (Genovese et al., 2014; Jaiswal et al., 2014; Xie et al., 2014a), whose occurrence increases with age. Moreover, whole-genome sequencing has revealed a more heterogeneous complexity of AML (Paguirigan et al., 2015), which could explain the difficulties in eradicating leukemic cells and avoid relapse (see section Resistance mechanisms of leukemias, page 33). 
Even though there has been major success in finding targets for different mutations involved in myeloid malignancies, there are still patients that lack efficient treatment options, including those without known driver mutations and elderly patients that are not eligible for high-dose chemotherapy or HSCT.

\section{Chronic and acute myeloid leukemia}

In 2012 approximately 350.000 patients were diagnosed with leukemia, making up $2.5 \%$ of all cancer cases worldwide (Ferlay et al., 2015). Patients developing leukemia share in common an abnormal clonal expansion of immature blood-forming cells in the blood circulation and BM. There are several types of leukemia that can be described as fast-growing (acute) or slow-growing (chronic), and these can be further divided into four main types of leukemia: acute myeloid leukemia (AML), chronic myeloid leukemia (CML), acute lymphocytic leukemia (ALL) and chronic lymphocytic leukemia (CLL).

CML is characterized by primitive hematopoietic progenitor cells pushed into circulation, which overproduce mature white blood cells that cannot function like normal white blood cells. In nearly all cases of CML, 95\% (Rowley, 1973), a translocation of the oncogene $A B L$ from chromosome 9 to the $B C R$ gene on chromosome $22, \mathrm{t}(9 ; 22)$, results in a constitutively active BCR-ABL tyrosine kinase (TK) (Shtivelman et al., 1986) that induce malignant cell transformation by maintaining proliferation, inhibiting differentiation and conferring resistance to cell death (Quintas-Cardama \& Cortes, 2009).

AML, which after ALL is the second most common type of leukemia in children (Bhatia \& Neglia, 1995), originates in the cells in the BM, and is described as acute since AML progresses quickly without treatment due to buildup of immature non-functional blasts. Nearly half of AML cases display a normal karyotype (Cancer Genome Atlas Research et al., 2013) and even though AML displays lower number of mutations than any other adult cancer studied (Lawrence et al., 2013), it lacks a common genetic target making it a harder disease to treat. Approximately one fourth of patients younger than 60 years diagnosed with AML carry internal tandem duplications (ITDs) in the juxtramembrane domain of FLT3 that induce autophosphorylation of the receptor and render FLT3 constitutively active, giving the cell a survival and proliferative advantage (Dohner et al., 2015; Konig \& Levis, 2015). Furthermore, $7 \%$ of the AML patients overexpress wildtype FLT3 mainly through activating point mutations of the TK domain (Yamamoto et al., 2001).

\section{Chemotherapy}

A patient diagnosed with leukemia is treated with chemotherapy or allogeneic HSCT. The worldwide standard of chemotherapy for AML since more than four decades is the combinatorial use of anthracyclines, which are among the most effective anticancer drugs, and cytarabine (Ara-C) (Yates et al., 1973). Daunorubicin is an example of anthracycline that by DNA interaction inhibits the enzyme topoisomerase II and leading to interfered 
transcription (Pommier et al., 2010; Yang et al., 2015). Cytarabine incorporates into DNA in the S phase of cell cycle and inhibits DNA replication and cell division (Braess et al., 2000), which induces apoptosis. Anthracyclines and cytarabine are also believed to stimulate ROS production of their cellular sources or inhibiting the antioxidant systems, which could induce cell death (Prieto-Bermejo et al., 2018). Furthermore, vincristine is another cytostatic that can be used for treatment of leukemia, which through binding to the microtubules and subsequent inhibition of mitosis induces apoptosis of leukemic cells (Kothari et al., 2016).

About two decades ago, all previous treatments for CML were displaced by the discovery of receptor tyrosine kinase (RTK) inhibitors, particularly for BCR-ABL. The first approved RTK inhibitor was Imatinib (Gleevec) that is still the standard treatment for many patients after failure of other treatments (Baccarani et al., 2013; O'Brien et al., 2003). Targeting CML patients carrying BCR-ABL with Imatinib, which by binding to the fusion protein inhibits autophosphorylation and the subsequent activation of downstream targets, results in normalized white blood cell count, increased patient survival and overall better remission (Jabbour et al., 2013; Kantarjian et al., 2002). However, Imatinib resistance and intolerance has led to the development of additional RTK inhibitors. The second-generation RTK inhibitors include dasatinib (Hochhaus et al., 2007) and nilotinib (Kantarjian et al., 2007), which are approved for first-line therapy and in relapsed CML and where initial findings have shown benefits of the second-generation RTK inhibitors over Imatinib (Cortes et al., 2016; Hochhaus et al., 2016). The third-generation ponatinib is used when other RTK inhibitors do not work, or if the leukemic cells carry the T315I mutation (Poch Martell et al., 2016). The RTK inhibitor Midostaurin (PKC412) induces cell cycle arrest and apoptosis of leukemic cell lines through inhibition of FLT3 mutations (Weisberg et al., 2002) and is one of several lowmolecular weight inhibitors that has been shown to be efficient in the combination with standard chemotherapy to prolong overall survival of AML patients carrying FLT3 mutations (Stone et al., 2015; Stone et al., 2017).

\section{Resistance mechanisms of leukemias}

Although chemotherapy results in high rates of remission, relapse represents the major cause to why treatment eventually fails (Dohner et al., 2015). Therefore the survival rates, especially for acute leukemias, are low and the majority of patients diagnosed with AML have a poor prognosis with an overall 5-year survival rate of 40-45\% when under the age of 60 , and less than 10\% when older than 60 years (Dohner et al., 2010). Since the damage inflicted by the anticancer drugs triggers cell death by interfering with cellular processes essential for maintenance of viability or by activating intracellular signaling pathways regulating cell death, multidrug resistance (MDR) could arise from cellular defenses involved in diverse mechanisms, including limiting the access of the drug or prevent the cell from entering apoptosis. 


\section{Leukemic stem cells}

The existence of leukemic stem cells (LSCs) has been shown for leukemias and was firstly evidenced in AML (Lapidot et al., 1994), where cells with the same phenotype as normal human stem cells, i.e., $\mathrm{CD} 34^{+} \mathrm{CD} 38^{-}$, had the potential to initiate and maintain the development of AML in xenograft experiments (Bonnet \& Dick, 1997). The LSC could either be derived from its normal counterpart, where CML has been shown to originate from transformation of HSCs (Huntly \& Gilliland, 2005; Woll et al., 2014), or from a more committed progenitor like the more aggressive AML that can originate from transformed progenitors (Goardon et al., 2011) that reacquire the ability to self-renew and maintain leukemia (Krivtsov et al., 2006; Wang et al., 2010). The quiescent state of which LSCs are residing in seems to protect the LSCs from chemotherapy that targets highly proliferating cells (Corbin et al., 2011; Graham et al., 2002; Guan et al., 2003). Hence, the failure to cure leukemia, especially AML, and the high risk of recurrence and drug resistance could be attributed to LSCs.

\section{$A B C$ drug transporters}

An increasing number of ATP-binding cassette $(\mathrm{ABC})$ drug transporters have been shown to cause MDR to chemotherapy by the active efflux of anticancer agents and lowering the intracellular concentration of the drug, including ABCB1 (MDR1), ABCC1 (MRP1) and ABCG2 (BCRP1). Upon treatment of CML patients with Imatinib leukemic cells expressed more ABCB1 (Burger et al., 2005), as well as ABCC1 and ABCG2 (Stromskaya et al., 2008). ABC transporters overexpressed in AML patients (Marzac et al., 2011) and CML patients (Eadie et al., 2017) seem to contribute to chemoresistance and have been shown to function as prognostic factors. Furthermore, expression of ABCG2 may lead to treatment failure in AML due to efflux of its substrate daunorubicin (Svirnovski et al., 2009). HIFs have been suggested as mediating chemoresistance by overexpression of ABC transporters, especially HIF- $1 \alpha$ by activation of $A B C B 1$ (Comerford et al., 2002) and HIF-2 $\alpha$ by activation of $A B C G 2$ (Martin et al., 2008).

\section{Alternative resistance mechanisms}

Point mutations in the target proteins for specific inhibitors, or development of intracellular mechanisms associated with apoptotic signaling leading to survival advantage in leukemic cells are other mechanisms by which leukemic cells can escape treatment and acquire MDR. It is known that most FLT3 inhibitors are active against FLT3-ITD, but less against FLT3 TK domain mutations. If the latter mutations are present at diagnosis or acquired upon treatment, resistance to FLT3 inhibitors can develop (Grundler et al., 2003). The first clinical resistance mutation was identified in a FLT3-ITD patient who relapsed after treatment with Midostaurin, where a point mutation within the TK domain prevented Midostaurin from binding (Heidel et al., 2006). FLT3-ITD has also been shown to induce upregulation of the antiapoptotic protein 
MCL-1 (Breitenbuecher et al., 2009) and constitutive activation of the STAT signaling pathway (Kim et al., 2005), all mediating resistance to FLT3 inhibition. Furthermore, prolonged treatment of human leukemic cell lines with FLT3 inhibitors has been shown to select for leukemic clones lacking secondary mutation in FLT3 but with continuous PI3K/AKT and Ras/MAPK downstream signaling (Piloto et al., 2007), and FLT3independent overexpression of antiapoptotic proteins of the BCL-2 family was found in primary blasts with FLT3 mutations (Kohl et al., 2007). This upregulation of compensatory signaling pathways mediates survival/proliferation signals upon FLT3 inhibition.

The importance of clonal evolution has been discovered by utilizing whole-genome or whole-exome sequencing, or single-cell sequencing (Ding et al., 2012a; Jan et al., 2012; Paguirigan et al., 2015). In a study where samples from eight AML patients were taken at diagnosis and relapse, respectively, to define clonal evolution of AML (Ding et al., 2012a), it was discovered that initial leukemic clones were not eradicated by chemotherapy. These founder clones could either acquire a relapse-associated mutation during treatment, or a subclone could survive treatment and acquire additional mutations, both leading to expansion of the clone and relapse of the patient (Figure 10). Furthermore, in a recent study by Christopher et al., utilizing whole-exome sequencing, it was discovered that relapse of AML patients after allogeneic transplantation may be associated with dysregulation of pathways involved in adaptive and innate immunity, including downregulation of MHC class II genes, which could lead to decreased immune response and defective graft-versus-leukemia effect (Christopher et al., 2018).

In summary, mutations in the drug target proteins and cell intrinsic events seem to lead to emergence of chemoresistance.

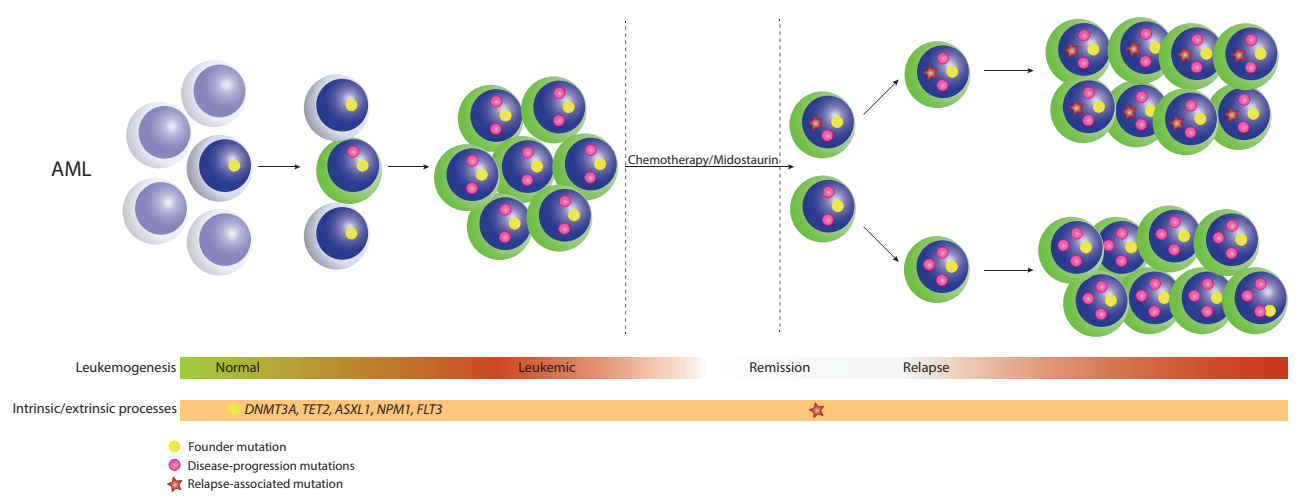

Figure 10. Clonal evolution of acute myeloid leukemia. Some of the most common founding mutations in acute myeloid leukemia (AML) arise in the somatic genes DNMT3A, TET2, ASXL1, NPM1 and FLT3. The leukemic clone acquires mutations in genes contributing to disease progression and expansion of the leukemic cells. After chemotherapy or treatment with inhibitor (Midostaurin) this clone could either gain relapseassociated mutations, or a subclone that survived treatment gains additional disease-progressing mutations, ultimately leading to relapse. Adapted with modifications from (Ferrando \& Lopez-Otin, 2017), with permission. 


\section{Bone marrow interactions and hypoxia}

The contribution of the BM to drug resistance of LSCs and progenitor cells is believed to contribute with viability signals and to protect the LSCs from the effects of inhibitors (Ishikawa et al., 2007; Konopleva \& Jordan, 2011; Zhou et al., 2016). While leukemic FLT3ITD blasts in the blood are markedly reduced upon treatment, bone marrow responses are less common (Smith et al., 2004), which seem to be caused by the development of drug resistance. CXCR4 is upregulated on AML cells and on CML BCR-ABL ${ }^{+}$cells upon chemotherapy and Imatinib treatment, respectively, rendering a protective homing of leukemic cells to the niche (Jin et al., 2008; Sison et al., 2013). Inhibition of CXCR4 on leukemic cells in vitro and in vivo enhanced chemotherapy- and RTK inhibitor-induced apoptosis of both CML and AML (Jin et al., 2008; Nervi et al., 2009; Zeng et al., 2009), and blocking of CXCR4 in xenograft models mobilize CML cells from the BM niche, leading to better in vivo eradication (Weisberg et al., 2012).

The low oxygen level in the BM as a regulatory feature of myeloid malignancies and its influence on maintenance and chemotherapy resistance has been studied in several experimental models. Leukemic cells in both AML and CML might benefit from hypoxia, which could explain the difficulty in eradicating leukemic cells residing in the BM with conventional drugs or RTK inhibitors.

The hypoxic environment of the BM induces decreased proliferation of AML blasts, protecting the cells from chemotherapy in the form of cytarabine (Drolle et al., 2015). In vitro culture of CML cell lines in hypoxia revealed an heterogeneity for hypoxia-resistance, where the cell lines comprised both hypoxia-sensitive colony-forming cells as well as hypoxiaresistant immature progenitor cells (Giuntoli et al., 2006). The latter population showed completely suppressed BCR/ABL protein and was Imatinib-insensitive, suggesting a role for hypoxia in promoting chemoresistance by maintaining BCR/ABL-independent cells. Later it was shown that this population lose the oncogenic protein upon shortage of glucose (Giuntoli et al., 2011), indicating that adaption to energy shortage in combination with suppression of BCR/ABL enables this cell subset to survive in the hypoxic BM niche. Furthermore, hypoxic in vitro culture of primary $\mathrm{CD} 34^{+}$cells from CML patients inhibited proliferation of $\mathrm{CD} 34^{+}$ cells and enhanced the maintenance of colony-forming cells (Desplat et al., 2002). These results are altogether implicating a role for stroma-derived as well as hypoxia-mediated chemoresistance.

\section{Role of HIFs in leukemia}

Since hypoxia seems to regulate maintenance and resistance of leukemia cells the role of HIF-1 $\alpha$ in mediating these responses has been studied. In a recent study using a mouse model of CML it was shown through HIF-1 $\alpha$ deletion that signaling of the cyclin-dependent kinase (CDK) inhibitors p16 and p19 was induced leading to inhibited cell cycle progression, indicating the importance of HIF-1 $\alpha$ in leukemia development (Zhang et al., 2012). Also, 
HIF- $2 \alpha$ has been studied regarding its role in leukemia, where it seems to be involved in apoptosis protection of AML cells through upregulation of antioxidant enzymes as well as reduction of ER stress (Rouault-Pierre et al., 2013). Upon the use of short hairpin (shRNA) to knock down the expression of HIF- $2 \alpha$ in leukemic blasts, unfolded protein response (UPR) pathway was triggered by mitochondrial ROS, resulting in decreased AML engraftment. shRNA against $H I F-1 \alpha$ in human $\mathrm{CD} 34^{+} \mathrm{CD} 38^{-}$AML cells showed the same impaired engraftment when transplanted to immunodeficient NOD/SCID mice (Wang et al., 2011b). Furthermore, by xenograft transplantation of $\mathrm{CD} 34^{+}$cells from CML patients incubated in vitro at hypoxia before transplantation into NOD/SCID-IL2Rg ${ }^{\text {null }}$ (NSG) mice, hypoxia was shown to support LSC maintenance of $\mathrm{BCR}-\mathrm{ABL}^{+}$cells and resistance to RTK inhibitors $(\mathrm{Ng}$ et al., 2014). HIF-1 $\alpha$ in the leukemic cells was shown to be stabilized in vitro by hypoxia, and suggested to contribute to the resistance to Imatinib. Finally, anthracyclines, including daunorubicin, have been shown to inhibit HIF-1 $\alpha$ through its ability to disrupt DNA strands and thereby the binding of HIF-1 $\alpha$ to its target genes (Lee et al., 2009). In summary, these studies implied that HIF- $1 \alpha$ and HIF- $2 \alpha$ are required for maintenance of LSCs and leukemic blasts, making them promising targets for AML treatment.

There are however now studies challenging the importance of HIF signaling pathways in LSCs. In a recent study by Velasco-Hernandez et al. utilizing three different murine AML models, there was no evidence of HIF-1 $\alpha$ requirement for leukemia initiation or LSC selfrenewal (Velasco-Hernandez et al., 2014). Furthermore, HIF-1 $\alpha$ deletion in FLT3-ITD knockin mice rather results in increased proliferation and faster development of myeloproliferative disease with shorter survival (Velasco-Hernandez et al., 2015), with maintained disease upon transplantation of c-kit-enriched $H I F-1 \alpha^{\Delta / 4} / F L T 3-I T D$ cells to recipient mice. Finally, conditional deletion of $H I F-2 \alpha$ accelerates development of LSCs, and combined HIF-1 $\alpha$ and $H I F-2 \alpha$ deletion further potentiated AML progression, but was shown to be dispensable for disease maintenance (Vukovic et al., 2015). Thus, HIFs could, compared to previous results indicating their importance in AML, instead act as tumor suppressors. Conclusively, hypoxia seems to induce resistance mechanisms of LSCs, but divergent results question the role of HIFs in AML and require further studies. 


\section{METHODOLOGY}

Detailed descriptions of used methods are found in the material and methods section of the papers included in this thesis. Methods of central importance for the work are described more thoroughly in the following section.

\section{Flow cytometry}

Flow cytometry is a method used to analyze single cells by antibody staining of specific surface markers and intracellular molecules. The antibodies are conjugated with different fluorochromes that can be excited by lasers with different wavelength as the cells pass by the cuvette of the flow cell (Adan et al., 2017). The emitted light is reflected or passes through filters that separate light of different wavelengths to enable detection of light from several sources at the same time. The light can thereafter be collected by the detectors in the form of photomultiplier tubes, where the photons are converted to electrons and the electronic signal is sent to the computer for analysis. Moreover, general size and granularity can be analyzed via the forward and sideway scattering of light, respectively.

FACS is used to sort cells for further assays (Adan et al., 2017). The sample of cells runs from the sample tube to the cuvette flow cell where hydrodynamic forces of pressurized sheath fluid and the nozzle focus the sample into a single-file stream. Single cells pass by the interrogation point of the lasers, after which the stream is partitioned into droplets. When a target cell is detected, a charge is applied to the droplet that contains the target cell. Thereafter, the droplets pass through an electric field generated by deflection plates, where charged droplets are pulled towards the plates and collection tubes, and uncharged droplets pass into the waste. The BD FACSARIA high-speed cell sorter used for our experiments can sort approximately 20000 cells/second.

Different lasers excite the fluorochrome-conjugated antibodies, and the type of lasers and filters of the flow cytometry instrument determines the number and types of fluorochromes that can be selected. The BD FACSCanto II and BD FACSARIA used for our experiments have a $405 \mathrm{~nm}$ (violet), $488 \mathrm{~nm}$ (blue) and $633 \mathrm{~nm}$ (red) laser, with an additional $355 \mathrm{~nm}$ (UV) laser for the FACSARIA, and where the color represents the wavelength emitted by the laser (Picot et al., 2012). The lasers can excite 2-6 different fluorochromes, giving the possibility to distinguish 14 colors in one sample at the same time with the FACSARIA instrument.

\section{Mouse models}

Mice are widely used as a model system for HSCs since they are relatively inexpensive, can be raised in large numbers and have an easily manipulated genome. Furthermore, mice enable transplantation experiments to study the developmental potential of different hematopoietic cell types. They exhibit many physiological similarities to humans, but there 
are differences when it comes to hematopoiesis, and the results from mice should not without thought be interpret to humans.

For the papers in this thesis we have used congenic as well as transgenic mice, all of the C57BL6 strain, which is the most commonly used mouse strain to study hematopoiesis. For transplantation experiments, congenic mouse strains, which differ in a single locus but otherwise are genetically identical, are used. Leukocytes can be distinguished by their expression of CD45.1 or CD45.2 forms, respectively, and enables selective tracking of test cells and competitor cells post-transplantation (Figure 2, page 11). The competitive bone marrow fraction is also necessary to support the hematopoietic tissue initially before primitive stem and progenitor cells have produced mature and functional hematopoietic cells. Transgenic animals, which have foreign DNA introduced into their genome, are used for studying the impact of specific genes in complex biological processes. The results in this thesis is based on the use of Mxl-Cre:Hif-1 $\alpha$ and vav:Bcl-2 transgenic mice, where Cre and $B c l-2$ under the control of hematopoietic restricted $M x l$ and vav gene regulatory sequences, respectively, makes it possible to specifically study a gene only in the hematopoietic system. Mxl:Cre (Kuhn et al., 1995) represents the most common conditional knockout model for hematopoiesis, where $M x 1$ promoter is activated in an interferon-dependent manner by injection of polyinosinic:polycytidylic acid (pIpC), which induce the Cre recombinase to efficiently excise the Hif-1 $\alpha$ gene (Ryan et al., 2000). In the vav:Bcl-2 mouse, which is a noninducible mouse model, BCL-2 is constitutively expressed in hematopoietic cells (Ogilvy et al., 1999) from embryonic day 11.5 (Bustelo et al., 1993).

\section{Lentiviral and retroviral vectors}

The discovery of RNA interference (RNAi) has resulted in the development of a valuable technique to study gene function by delivery of small interfering RNAs (siRNAs) and shRNAs into mammalian cells. siRNA is delivered directly to the cytosol and offers transient knockdown of a gene, while shRNA is introduced through infection (transduction) with viral vectors, which allows stable integration into the host cell DNA and long-term knockdown of the targeted gene. Lentivirus are able to enter an intact nuclear membrane allowing them to infect both dividing and non-dividing cells (Case et al., 1999), while retroviruses can only infect dividing cells when the membrane has disassembled during mitosis (Roe et al., 1993). RNAi is triggered by the cytoplasmic delivery of double-stranded RNA (dsRNA) identical to the target sequence, inducing sequence-specific degradation of mRNA. These shRNAs consist of two complementary 19-22 nucleotides long sequences linked by a short loop of nucleotides similar to the hairpin found in endogenous micro-RNA (miRNA). When transcribed, the shRNA sequence is transferred to the cytoplasm and recognized by the enzyme Dicer for processing to shorter siRNAs. Just as the exogenously delivered siRNA, this endogenously derived siRNA assembles into the RNA-induced silencing complex (RISC) for unwinding of the helix and degradation of the sense strand. The single-strand RNA-RISC complex binds the target mRNA for cleavage and degradation. 
In our experiments we used lentiviral delivery of shRNA to achieve transient silencing of target genes in non-dividing primary cells, where the vector containing shRNA oligos in addition contains a gene encoding for the selection marker GFP, which enables sorting of cells expressing shRNA shortly after introduction of the viral vectors. Moreover, we have used locked nucleic acid (LNA ${ }^{\mathrm{TM}}$ ) technique to inhibit RNA function, where stable, highaffinity RNA-analogs highly specific for a certain complimentary mRNA sequence induce longer-lasting gene silencing effect. Finally, we used retrovirus for delivery of a vector containing a gene encoding for oxygen-insensitive HIF- $1 \alpha$ or HIF- $2 \alpha$.

\section{Microarray}

Microarray analysis is a method to detect the expression of thousands of genes simultaneously, and can be used to identify genes that might be significant in a specific cellular response mechanism. mRNA is collected from samples and converted into complementary DNA (cDNA), which can be labeled by a wide variety of methods, including incorporation of fluorescently labeled nucleotides during synthesis or incorporation of a biotin labeled nucleotide, which is subsequently stained with fluorescent labeled streptavidin. On the microarray chip multiple copies of specific DNA sequences or genes are immobilized, complimentary to the cDNA targets produced from sample mRNA. Hybridization of the labeled target with the specific immobilized probe results in a signal identifying which RNAs are present, and the fluorescence intensity reflects the amount of DNA of a given gene in the sample.

Algorithms are used for the data normalization, whose goal is to eliminate non-biological differences between samples that originate from technical aspects of the microarray handling and to make data from different arrays comparable. In our experiment the raw data was background corrected and normalized with robust multi-array average (RMA) procedure, and thereafter LIMMA was used to assess the significantly expressed genes, which can be used for multifactor designed experiments and provides the ability to analyze comparisons between many targets simultaneously. To validate the results from microarray we confirmed the upregulation of some of the detected genes by quantitative real-time PCR (q-PCR). 


\section{AIMS AND HYPOTHESES OF MY THESIS}

The overall aims of my thesis were:

- to investigate mechanisms induced by hypoxia that regulate metabolism and energy production in HSPCs as well as protecting them against oxidative stress, with main focus on the transcription factor HIF- $1 \alpha$

- to identify mechanisms by which hypoxia protects leukemic cell lines from chemotherapy and inhibitors

- to examine whether hypoxia can maintain and expand HSCs better than normoxia in in vitro cultures and increase the engraftment upon transplantation to mice

One of our hypotheses was to assess whether HSCs in hypoxia relies more on glycolysis compared to HSCs in normoxia, and in that regard is central for the maintenance of their selfrenewal capacity.

Taking into consideration that HSCs have been shown to rely more on glycolysis than on mitochondrial energy production in the hypoxic niche, we also stated the hypothesis that hypoxia via HIF-1 $\alpha$ protects HSCs from oxidative stress-induced cell death as opposed to normoxia, and by this maintains HSCs.

Furthermore, since hypoxia has been suggested to maintain HSCs in vivo we reasoned that hypoxic conditions during in vitro culture could be utilized to experimentally maintain HSCs and possibly promote their expansion.

Finally, since it is known that a majority of patients diagnosed with leukemia experience relapse after initial treatment, and interaction of leukemic cells with the BM niche could contribute to the difficulty of eradicating leukemic cells with drugs, we hypothesized that hypoxia induces resistance to chemotherapy in leukemic cells. 


\section{SUMMARY OF THE PRESENT INVESTIGATION}

\section{Results and discussion}

\section{Paper I}

In an attempt to better understand hypoxia-induced metabolic regulation in HSCs, in paper I we investigated hypoxia-inducible genes involved in the conversion of energy metabolism from the mitochondria to glycolysis. The starting point was results from other researchers studying the role of hypoxia, mainly in other cell types and tissues, that had demonstrated that hypoxia in comparison to normoxia relies more on glycolysis for energy production. If this would be true for HSCs, it could explain how hypoxia maintains HSCs for lifetime by reduced levels of ROS. With focus on the gene family of PDK1-4, we could demonstrate that $P d k 1$ is expressed at higher levels in HSCs including LT-HSCs, ST-HSCs, and MPPs compared to more differentiated cells and that $P d k 1$ expression, together with other genes involved in regulating metabolism, is upregulated in LSK cells by hypoxia and inducing a metabolic shift to glycolysis. Although expression of $P d k 2$ and $P d k 3$ was higher in LT-HSCs compared to differentiated cells, they were not regulated upon hypoxic exposure. Furthermore, in our study we could not detect expression of $P d k 4$ at all. These results stand in contrast to a study by Takubo et al. that during the course of our work showed that Pdk2 and Pdk4 were involved in the metabolic conversion by hypoxia and being important for maintaining HSCs (Takubo et al., 2013). Our results also suggested that $P d k l$ was not only expressed at higher levels in HSCs but also in MPPs. To elucidate if the effects on PDK1 were mediated by HIF$1 \alpha$, we utilized several different approaches manipulating HIF- $1 \alpha$ protein expression and stability. Overexpression in LSK cells by the use of constitutively active HIF-1 $\alpha$ as well as hypoxic in vitro culture of Hif- $1 \alpha$ deficient BM progenitors provided evidence for induction of $P d k 1$ in hypoxia by HIF-1 $\alpha$. Surprisingly, no difference in the expression levels for $P d k 1$ was seen between fresh BM cells from Hif-1 $\alpha$ deficient mice and normal wildtype mice, raising questions to whether HIF- $1 \alpha$ regulates PDK1 differently during in vivo and in vitro conditions.

To assess whether PDK1 is involved in the ability of HSCs to reconstitute the hematopoietic system upon transplantation, lethally irradiated mice were reconstituted with LSK cells transduced with a lentiviral vector containing shRNAs targeting Pdkl. The engraftment potential at 4,8 and 16 weeks was significant lower in recipients transplanted with cells silenced for $P d k 1$, but no effects were seen on any specific cell lineage. When studying the cells in vitro lack of $P d k l$ partially impaired progenitor colony formation. Together these results suggested an important role of PDK1 downstream of HIF-1 $\alpha$ in regulating HSC function. Based on the findings that PDK1 is important for engraftment and the high expression of Pdkl in both LT-HSCs and MPPs, we decided to investigate if PDK1 has separate roles in MPPs and LT-HSCs. While LT-HSCs are thought to reside in hypoxic niches in the marrow, MPPs could locate to other sites where the level of oxygen might be 
significantly higher. Alternatively, both cell types regardless of location could rely on hypoxia for metabolic regulation. To investigate this, cells with silenced $P d k l$ were transplanted to mice. Both long-term and short-term reconstitution was impaired, demonstrating that the hypoxia-mediated glycolytic shift via PDK1 is essential not only in long-term HSCs but also in more restricted progenitors. This is in accordance with a previous study showing that HSCs deficient for HIF- $\alpha$ dimerization subunit Arnt resulted in minimal but significant changes in the expression of $P d k 1, P d k 2$ and $P d k 4$ (Krock et al., 2015). In summary, the novel findings of paper I was that PDK1 is a critical factor for maintaining the engraftment capacity of both LT-HSCs and MPPs, and that it is upregulated in hypoxia by HIF-1 $\alpha$ in vitro.

\section{Paper II}

Since HSCs reside in a hypoxic BM environment, that not only inhibits mitochondrial energy metabolism and leads to lower accumulation of ROS, but also preserves HSC properties, it has been assumed that hypoxia confers resistance to oxidative stress in HSCs (Ito et al., 2006; Jang \& Sharkis, 2007; Simsek et al., 2010). However, it remained an open question whether such effects are mediated by hypoxia per se or by hypoxia-induced transcriptional programs, in particular by HIF-1 $\alpha$, the major regulator of the hypoxic response. In paper II, the working hypothesis was that hypoxia via HIF-1 $\alpha$ protects HSCs from oxidative stress-induced cell death as opposed to normoxia, and by this maintains HSCs. An indication for this concept would be that more primitive hematopoietic cells displayed lower ROS levels than more differentiated cells.

Indeed, we could demonstrate that LT-HSCs and ST-HSCs displayed lower ROS levels than more differentiated progenitors, e.g., MPPs and CMPs. As these results indicated that hypoxia can protect HSCs from ROS-induced cell death, we next challenged freshly sorted LSK cells from mouse BM with ROS by adding DL-buthionine-(S,R)-sulfoximine (BSO), a selective irreversible inhibitor of $\gamma$-glutamylcysteine synthetase ( $\gamma$-GCS) (Figure 11) (Griffith, 1982), which mainly decreases the level of cytoplasmic glutathione, an antioxidant that plays a critical role to detoxify ROS, and exists in both an oxidized (GSSG) and reduced form (GSH).

While LSK cells cultured in normoxia showed increasing cell death with higher BSOconcentrations, hypoxia was able to protect LSK cells from such effects even at high levels of BSO. Trying to elucidate the molecular mechanisms, it was shown that hypoxic precondition could not delay LSK from oxidative stress when placed in normoxia. Similar, LSK cells first incubated in normoxia for 24 hours and then transferred to hypoxia for an additional 24 hours were not rescued, indicating that oxidative-stress induced cell death is a rapid adaptation to the oxygen levels provided by the environment. In support of this hypothesis, LSK cells preexposed to oxidative stress in hypoxia preserved the ability to engraft the BM upon transplantation to recipient mice, which was not the case for cells in normoxia. Thus, hypoxia protected the cells from ROS induced assault. We also tried to mimic the effects by other stimuli protecting against ROS accumulation and induction of apoptosis. To this end, 
apoptosis in vitro in LSK cells cultured in normoxia was blocked either with addition of the well-known antioxidant NAC or by LSK cells overexpressing the anti-apoptotic BCL-2 protein. This indicated that the mechanism of cell death is linked to the intracellular levels of ROS.

As HIF-1 $\alpha$ is highly expressed in HSCs and regulates their function and metabolism (Du et al., 2014; Takubo et al., 2010; Takubo et al., 2013) we next tested whether HIF-1 $\alpha$ was involved in the protection of HSCs to oxidative stress by overexpression and knockdown experiments, and by the use of LSK cells from conditional knock out mice lacking Hif-1 $\alpha$. Surprisingly, these studies demonstrated that HIF-1 $\alpha$ was not involved in oxidative stress resistance in hypoxia, which however is in agreement with a recent study suggesting that inducible deletion of Hif-1 $\alpha$ has no impact on HSC survival (Vukovic et al., 2016). Thus, involvement of other mechanisms inducing cell death due to oxidative stress, such as mitochondrial respiration, was considered. We decided to study $\operatorname{Sod} 2$ and $\mathrm{Cat}$, which are downstream target genes of HIF-2 $\alpha$. However, overexpression of HIF-2 $\alpha$ had no impact on cell survival in normoxia and both microarray data and q-PCR data showed no significant upregulation of Sod2 and Cat in hypoxia.

In addition to HIFs, there are other signaling pathways induced by hypoxia that could be involved in protection of HSCs against oxidative stress. Preliminary results did indicate a possible role for the transcription factor $\mathrm{NF}-\kappa \mathrm{B}$, which has been shown in hypoxia to be activated by the same PHDs as HIF- $1 \alpha$ (Cummins et al., 2006). NF- $\kappa B$ activity was studied, which showed that NF- $\mathrm{BB}$ could be involved in protecting LSK cells from oxidative stress in hypoxia. We conclude that hypoxia maintains HSCs through both HIF-1 $\alpha$-dependent, as previously shown regulating a metabolic shift to glycolysis, and independent mechanisms, by protecting against oxidative stress possibly mediated by NF- $\kappa \mathrm{B}$.

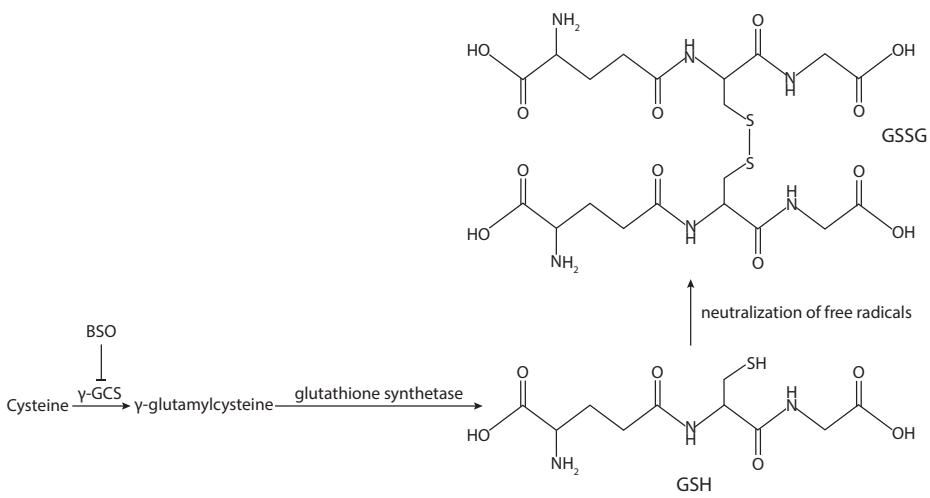

Figure 11. Simplified schematic illustration of GSH synthesis. The antioxidant glutathione (GSH) is synthesized from cysteine and the reaction is catalyzed by the enzymes $\gamma$-glutamylcysteine synthetase $(\gamma$-GCS) and glutathione synthetase. Scavenging of free radicals generate oxidized glutathione (GSSG). Depicted is DLbuthionine-(S,R)-sulfoximine (BSO), which inhibits the enzyme $\gamma$-GCS, and thus the synthesis of GSH. 


\section{Paper III}

Since hypoxia have been suggested to maintain HSCs in vivo (Harrison et al., 2002; Nombela-Arrieta et al., 2013; Spencer et al., 2014), Eliasson et al. in a previous report investigated whether hypoxic pre-exposure in vitro before transplantation could promote HSC expansion (Eliasson et al., 2010). In brief, they could show that hypoxia diminishes cell cycle through upregulation of the CDK inhibitors p21, p27 and p57 in LSK cells. Although the proportion of long-term engrafting HSCs was higher in hypoxic cultures compared to normoxia, no significant evidence for better engraftment potential of HSC after 4 days of hypoxic culture was demonstrated. This was contradictory to previous studies, indicating that hypoxic culture of murine BM cells (Ivanovic et al., 2000; Ivanovic et al., 2002) and human cord blood CD34 ${ }^{+}$cells (Danet et al., 2003; Shima et al., 2009) maintained the repopulation capacity better. Moreover, the findings was commented shortly thereafter in Experimental Hematology by Guitart et al. (Guitart et al., 2010) as inconclusive and dependent on the numbers of transplanted cells (2,000 LSK cells per mouse). The argument was that the approach of limiting-dilution assays taken by others should have been applied. Previous murine studies testing the effects by hypoxia on engraftment had used CFU-S assays 14 days after transplantation (Ivanovic et al., 2000) or in vitro experiments of secondary colonyforming cells from liquid cultures (Ivanovic et al., 2002), and not transplantation to study the ability of HSCs to support long-term in vivo hematopoiesis.

In paper III we therefore performed a limiting-dilution transplantation assay where LSK cells at doses ranging from 10 to 1,000 per mouse were injected into irradiated mice to exclude the possibility that excessive cell number would hide differences in number of HSCs cultured in hypoxia compared to normoxia. While the results implied that hypoxic incubation maintained almost 2-fold more long-term-reconstituting HSCs than normoxia, the results were not statistically conclusive. Thus, although hypoxia appears to be a component of the BM niche where HSCs reside, it does not seem to considerably contribute to mouse HSC expansion in vivo or to maintain the long-term engraftment ability, at least not in combination with the in vitro culture conditions used in our study.

\section{Paper IV}

In paper IV the ability of hypoxia to protect against treatment with chemotherapeutic drugs was investigated. Although chemotherapy initially results in remission in patients with leukemia, a majority of the patients experience relapse, and the treatment eventually fails and the patient succumbs to the disease. It has been shown that resistance to chemotherapy and inhibitors can be due to the existence of LSCs, which by their quiescent state escape treatment and by their self-renewal capacity maintain the disease (Corbin et al., 2011; Graham et al., 2002; Guan et al., 2003). Furthermore, except for mutations in genes regulating apoptotic signaling and interactions with the BM stroma, the hypoxic nature of the BM seems to inhibit

proliferation and mediate maintenance of leukemic cells. This could explain the difficulty in eradicating leukemic cells with conventional or novel drugs. In paper IV we examined 
human leukemia cell lines and the role of hypoxia in protection against conventional chemotherapeutic drugs as well as more novel RTK inhibitors. Numerous human leukemia cell lines carrying the BCR-ABL translocation, which drives uncontrolled cell proliferation and inhibits apoptosis (Melo \& Barnes, 2007), are available as models for CML. In paper IV, the K562 (Lozzio \& Lozzio, 1975), KCL-22 (Kubonishi \& Miyoshi, 1983) and KU812 (Kishi et al., 1984) cell lines were included. Similar, human AML cell lines were included, i.e., MV4;11 that carries a FLT3-ITD mutation conferring a proliferative and survival advantage (Quentmeier et al., 2003), and THP-1 (Tsuchiya et al., 1980) and HL-60 (Collins et al., 1977) expressing wildtype FLT3 but carrying other genotypic features.

We could show that incubation in hypoxia promotes slower cell cycle, and that hypoxic incubation reduces the sensitivity towards daunorubicin, vincristine and cytarabine that are used in treatment of AML. In addition, hypoxia lowered the sensitivity to the RTK inhibitors BCR-ABL (Imatinib) and FLT3-ITD (Midostaurin) that are used in treatment of CML and AML, respectively. Since this implied acquisition of MDR, and an increasing number of ABC drug transporters have been shown to be involved in MDR (Burger et al., 2005; Eadie et al., 2017; Marzac et al., 2011; Stromskaya et al., 2008), but also to be regulated by hypoxia and/or HIFs (Comerford et al., 2002; Martin et al., 2008), we decided to investigate the expression of $\mathrm{ABC}$ drug transporters in the leukemic cell lines. Preliminary data indicate that hypoxia mediates upregulation of $\mathrm{ABCC} 1, \mathrm{ABCG} 2$ (and $\mathrm{ABCB} 1$ in $\mathrm{CML}$ cell lines). Furthermore, addition of verapamil, an inhibitor of $\mathrm{ABC}$ drug transporters, restored the sensitivity to daunorubicin and vincristine in hypoxia to some extent.

Since HIF-1 $\alpha$ has been proposed to mediate chemoresistance by overexpression of ABC drug transporters (Comerford et al., 2002), we studied if HIF-1 $\alpha$ was mediating MDR. Although not yet convincingly confirmed, HIF-1 $\alpha$ was shown to be activated in the leukemic cell lines in hypoxia and initial findings pointed to HIF- $1 \alpha$-induced activation of ABC genes. The result from knockdown of $H I F-1 \alpha$ in K562 cells, which increased the susceptibility to daunorubicin, strengthens the putative role for HIF-1 $\alpha$ in hypoxia-mediated chemotherapy resistance. This is in accordance with another study that has shown that chemoresistance of CD $34^{+}$CML cells cultured in vitro in hypoxia seems to rely on HIF-1 $\alpha$ ( $\mathrm{Ng}$ et al., 2014).

In summary, hypoxia protects leukemic cells from chemotherapeutic drugs as well as RTK inhibitors, indicating the potential involvement of HIF-1 $\alpha$ and ABC target genes in MDR. However, additional experiments, including q-PCR and microarray, are necessary to confirm the preliminary data shown in this study. 


\section{Conclusions}

During my doctoral studies we have:

identified the importance of PDK1 in hypoxia, regulating a metabolic shift to glycolysis and maintaining the reconstitution ability of both HSCs and MPPs, and shown that PDK 1 is a target of HIF-1 $\alpha$ in vitro.

ruled out HIF-1 $\alpha$ as protecting LSK cells from oxidative stress-induced cell death in hypoxia, and instead identified a putative role for $\mathrm{NF}-\mathrm{kB}$.

provided further evidence by transplantation experiments that hypoxic in vitro cultures do not seem to expand the numbers of HSCs, nor to maintain long-term reconstituting HSC s better than normoxia.

demonstrated a possible role of hypoxia, and HIF-1 $\alpha$, in multidrug resistance in $A M L$ and $C M L$ cells as hypoxia upregulates $A B C$ transporter genes and thereby lowers the sensitivity to chemotherapeutic drugs and RTK inhibitors. 


\section{Future aspects}

This thesis adds novel knowledge to how hypoxia regulates HSC maintenance and protects against cell death in normal HSPCs as well as leukemic cell lines. During the course of my work however, new questions have emerged that still waits to be answered. With the focus on HIF-1 $\alpha$ we have discovered cellular pathways depending on HIF-1 $\alpha$, but also those that do not. Hence, we have identified NF- $\kappa \mathrm{B}$ to be involved in protection against oxidative stressinduced cell death in hypoxia. Future experiments need to be performed to answer if NF- $\kappa \mathrm{B}$ is one of the key factors for hypoxia-mediated protection of HSCs to ROS. The regulation of $\mathrm{NF}-\kappa \mathrm{B}$ activity is complex involving regulation by $\mathrm{I} \kappa \mathrm{Bs}$ and IKK, regulation of $\mathrm{NF}-\kappa \mathrm{B}$ subunits on post-translational level as well as interaction with cofactors. Therefore, a thorough study of NF- $\mathrm{NB}$ activity is necessary to understand how NF- $\kappa \mathrm{B}$ is regulating the hypoxia-mediated cell survival in HSCs when exposed to ROS. Investigating gene silencing of NF- $\kappa \mathrm{B}$ and the way it mitigates oxidative stress in hypoxia could provide valuable information. Furthermore, it would be interesting to compare NF- $\kappa \mathrm{B}$ activity in primary HSCs and committed progenitor cells cultured in normoxia or hypoxia to study if NF- $\kappa \mathrm{B}$ activity differs between cell populations.

My focus has been on the role of hypoxia for HSCs and how it provides critical regulation of stem cell features and maintenance. However, as discussed earlier, signals from other types of cells and factors in the body and specifically the BM niche are necessary for proper regulation of HSCs. Therefore, it would be valuable to study how hypoxia affects niche cells, and by co-cultivation of HSCs and stromal cells in hypoxia under oxidative stress investigate the potential protective role by niche cells. Furthermore, the addition of niche cells to HSC culture in hypoxia might contribute to maintenance of HSCs, which would be intriguing to study. Another very interesting experiment considering maintenance of HSCs in vitro would be to setup transplantation of LSK cells cultured in normoxia (CD45.1) or hypoxia (CD45.2), that subsequently are transplanted into CD45.1/CD45.2 mice, which means that into the same mouse both CD45.1 and CD45.2 cells could be injected and their competitive ability could be monitored in the same mouse. This could reveal what culture condition that best preserves the reconstitution capacity.

Although my doctoral work was mainly on normal HSCs, it would be essential to further study the role that hypoxia plays in leukemia. To continue studying HIF-1 $\alpha$ and ABC drug transporters regarding their role in chemoresistance is obvious, but it would also be intriguing to investigate the role of hypoxia and NF- $\kappa \mathrm{B}$ in leukemic cells and their potential therapeutic applications. By co-culture of leukemic cells with stromal cells in hypoxia the effects of niche-leukemic cell interactions on abrogation of drug effects could be investigated. So far, our studies have been performed on leukemia cell lines, but in order to evaluate the protective role of hypoxia on primary leukemic cells, freshly isolated CD $34^{+} \mathrm{AML}$ cells from patient cultured in hypoxia with chemotherapeutic agents would also be interesting to study. 


\section{ACKNOWLEDGEMENTS/TACK TILL}

The work in this thesis was supported by grants from Swedish Research Council, Swedish Cancer Society, Swedish Childhood Cancer Foundation, County Council of Östergötland, Faculty of Medicine at Linköping University and Ollie and Elof Ericssons Foundation.

I would like to start by telling everyone who has supported me during my time as a $\mathrm{PhD}$ student and contributed in different ways to the work resulting in this thesis, how grateful I am. Also, how lucky I am who got the opportunity to spend 9 years at "LabEttan". It is a joy coming to work every day and meet all nice colleagues, time flies when you are having fun!! Especially, I would like to thank the following:

Jan-Ingvar Jönsson, my supervisor. Attending your lecture about the immune system and "bubble baby disease" got me, the "engineer", hooked in the field of hematopoietic stem cells. Your enthusiasm for science, your broad knowledge and your ability to explain complex subjects in an understandable way is remarkable, and has made a visit to your office a guarantee to be inspired with new ideas and to get new energy for more experiments. Just make it work! $;$

Mikael Sigvardsson, my co-supervisor. Thank you for your brilliant ideas of experiments for my projects, and suggestions on how to solve the problems I have encountered in my research.

To all brilliant past and present colleagues in the Jönsson group, especially: Pernilla, for introducing me to the projects, your optimism and willing to teach (even when you were busy writing your own thesis) gave me so much. Amanda, my room mate for so many years, the sweetest. Thank you for all the laughs, both in the lab as well as during our trips together (you take snoozing to a whole new level). Tjolahopp, tjolahej!, never had a boring minute with you! Emma, my cheerful room mate for the last years. Thank you for proof-reading this thesis. I really appreciate having you behind my back (literally!), always answering my questions on everything under the sun and showing an incredible and contagious excitement for even the slightest differences based on the tiniest values. To our students Linda and Sandra, for your good spirits and willing to learn. Yan, Maria and Komal, for all help during bigger experiments.

The outstanding technichians. Pia, for organizing the lab, but mostly for being you! Always there ready to discuss questions about everyday life as well as helping with everything from multiple experiments set up by me in what might have seemed like impossible ways to hypoxia chambers not working for what felt like the hundreth of time. Glad that you kept me company so many mornings. Lotta, so warm-hearted, thank you for never hesitating to help with all sorts of things in the lab. Annika, Carolin and Helen, for your kindness, your great knowledge and for all nice small talks.

Margareta, for always being so helpful, especially with the preparations for my dissertation.

Josefine and Jenny, for all your tips and tricks regarding flow cytometry, for your moral support when measuring ATP, but mostly for your friendliness. Josefine, for your wonderful personality and sense of humor, and for liking the same type of movies (maybe not as much my choice of travel plans or early departures with simple transportations (read old trains not serving coffee) (:)).

Rajesh, Jonas and Tobias in the Sigvardsson group, for making the lab such a happy place! 
Tina, Johanna, Emmy and Rada, for the nice A W get-togethers, as well as all those fika at work. Tina, thank you for the much-needed breaks you always remind me of and for our talks, and sorry for all those "jag ska bara... ". Johanna, for your loving and caring personality, I really miss you! Emmy, for your kindness and for showing interest in my research. Special thanks to Rada for my cover picture, for proof-reading, but mostly for sharing the last months of this journey with me, your caring way and relaxed attitude has been invaluable. I am happy to have such great friends (and surprised that so many of us like the same kind of music (Labbrock;))!

To all past and present members and friends at "Labbettan", for invaluable advice, discussions and help when needed, and who have contributed to the positive atmosphere at work!

Stefan Klintström, Charlotte Immerstrand and all members in Forum Scientium, thank you for all interesting seminars and inspiring, as well as fun, study visits.

To all the staff at the animal facility and particularly to Nettan, Linda and Petra for your help with my transplantation experiments.

Florence and Micke, for making the flow cytometry core facility such a nice place!

Hong, Shamit and Stefan, for expert microarray help.

Nanny, Lina B, Maria and Frida O, for the nice monthly dinners. Lina $\mathbf{L}$ and Anneli for the fun get togethers we had after finishing our graduate studies. To my wonderful friends I made up in M ora. Especially Frida B, for having the expectation of me winning the Nobel Prize, and Katty and Fia, for letting me stay at your homes during my PhD courses in Stockholm and Gothenburg.

The Nilsson family, for al ways making me feel welcome from the first moment I met you, and for showing interest in what I do. I truly feel like a part of your family.

My family. To mum and dad who always welcome me home to Dalarna, love spending time with you. Thank you for believing in me and for supporting my choices in life, even though you sometimes have asked what I am actually doing and how many years one can spend in school (24 and counting... ;)). Cecilia, Carolina, Clara and Carl, my beloved siblings, growing up with you made me the person I am today (both good and bad I guess ()). L ove seeing you when coming "home"!

Ronny, my life partner and best friend for nearly 16 years. Thank you for supporting me and for following me through my studies and research, for all the trips we went for, for your incredible patience and for realizing all my crazy ideas. Y ou are amazing, love you!

Sist, och faktiskt även minst, Rut och Ivar, mina små mirakel. Era leenden och kramar jag mötts av i dörren under de senaste 4 månaderna har gjort det så mycket lättare. Ert fantastiska förhållningssätt till livet och alla era påhitt gör mina dagar så mycket roligare! Ä Iskar er så!! 


\section{REFERENCES}

Abbas, H. A., Maccio, D. R., Coskun, S., Jackson, J. G., Hazen, A. L., Sills, T. M., . . Lozano, G. (2010). Mdm2 is required for survival of hematopoietic stem cells/progenitors via dampening of ROS-induced p53 activity. Cell Stem Cell, 7(5), 606-617.

Acar, M., Kocherlakota, K. S., Murphy, M. M., Peyer, J. G., Oguro, H., Inra, C. N., . . Morrison, S. J. (2015). Deep imaging of bone marrow shows non-dividing stem cells are mainly perisinusoidal. Nature, 526(7571), 126-130.

Adan, A., Alizada, G., Kiraz, Y., Baran, Y. \& Nalbant, A. (2017). Flow cytometry: basic principles and applications. Crit Rev Biotechnol, 37(2), 163-176.

Adolfsson, J., Borge, O. J., Bryder, D., Theilgaard-Monch, K., Astrand-Grundstrom, I., Sitnicka, E., . . Jacobsen, S. E. (2001). Upregulation of Flt3 expression within the bone marrow Lin()Sca1(+)c-kit(+) stem cell compartment is accompanied by loss of self-renewal capacity. Immunity, 15(4), 659-669.

Adolfsson, J., Mansson, R., Buza-Vidas, N., Hultquist, A., Liuba, K., Jensen, C. T., . . Jacobsen, S. E. (2005). Identification of Flt3+ lympho-myeloid stem cells lacking erythro-megakaryocytic potential a revised road map for adult blood lineage commitment. Cell, 121(2), 295-306.

Akashi, K., Traver, D., Miyamoto, T. \& Weissman, I. L. (2000). A clonogenic common myeloid progenitor that gives rise to all myeloid lineages. Nature, 404(6774), 193-197.

Arai, F., Hirao, A., Ohmura, M., Sato, H., Matsuoka, S., Takubo, K., . . . Suda, T. (2004). Tie2/angiopoietin-1 signaling regulates hematopoietic stem cell quiescence in the bone marrow niche. Cell, 118(2), 149-161.

Audet, J., Miller, C. L., Rose-John, S., Piret, J. M. \& Eaves, C. J. (2001). Distinct role of gp130 activation in promoting self-renewal divisions by mitogenically stimulated murine hematopoietic stem cells. Proc Natl Acad Sci U S A, 98(4), 1757-1762.

Baccarani, M., Deininger, M. W., Rosti, G., Hochhaus, A., Soverini, S., Apperley, J. F., . . Hehlmann, R. (2013). European LeukemiaNet recommendations for the management of chronic myeloid leukemia: 2013. Blood, 122(6), 872-884.

Bakker, S. T. \& Passegue, E. (2013). Resilient and resourceful: genome maintenance strategies in hematopoietic stem cells. Exp Hematol, 41(11), 915-923.

Ballen, K. K., Gluckman, E. \& Broxmeyer, H. E. (2013). Umbilical cord blood transplantation: the first 25 years and beyond. Blood, 122(4), 491-498.

Becker, A. J., Mc, C. E. \& Till, J. E. (1963). Cytological demonstration of the clonal nature of spleen colonies derived from transplanted mouse marrow cells. Nature, 197, 452-454.

Benita, Y., Kikuchi, H., Smith, A. D., Zhang, M. Q., Chung, D. C. \& Xavier, R. J. (2009). An integrative genomics approach identifies Hypoxia Inducible Factor-1 (HIF-1)-target genes that form the core response to hypoxia. Nucleic Acids Res, 37(14), 4587-4602.

Bernad, A., Kopf, M., Kulbacki, R., Weich, N., Koehler, G. \& Gutierrez-Ramos, J. C. (1994). Interleukin-6 is required in vivo for the regulation of stem cells and committed progenitors of the hematopoietic system. Immunity, 1(9), 725-731.

Bernitz, J. M., Kim, H. S., MacArthur, B., Sieburg, H. \& Moore, K. (2016). Hematopoietic Stem Cells Count and Remember Self-Renewal Divisions. Cell, 167(5), 1296-1309 e1210.

Berra, E., Benizri, E., Ginouves, A., Volmat, V., Roux, D. \& Pouyssegur, J. (2003). HIF prolylhydroxylase 2 is the key oxygen sensor setting low steady-state levels of HIF-1alpha in normoxia. EMBO J, 22(16), 4082-4090.

Bhatia, M., Bonnet, D., Kapp, U., Wang, J. C., Murdoch, B. \& Dick, J. E. (1997a). Quantitative analysis reveals expansion of human hematopoietic repopulating cells after short-term ex vivo culture. J Exp Med, 186(4), 619-624.

Bhatia, M., Wang, J. C., Kapp, U., Bonnet, D. \& Dick, J. E. (1997b). Purification of primitive human hematopoietic cells capable of repopulating immune-deficient mice. Proc Natl Acad Sci U S A, 94(10), 5320-5325.

Bhatia, S. \& Neglia, J. P. (1995). Epidemiology of childhood acute myelogenous leukemia. J Pediatr Hematol Oncol, 17(2), 94-100. 
Boitano, A. E., Wang, J., Romeo, R., Bouchez, L. C., Parker, A. E., Sutton, S. E., . . Cooke, M. P. (2010). Aryl hydrocarbon receptor antagonists promote the expansion of human hematopoietic stem cells. Science, 329(5997), 1345-1348.

Bonizzi, G. \& Karin, M. (2004). The two NF-kappaB activation pathways and their role in innate and adaptive immunity. Trends Immunol, 25(6), 280-288.

Bonnet, D. \& Dick, J. E. (1997). Human acute myeloid leukemia is organized as a hierarchy that originates from a primitive hematopoietic cell. Nat Med, 3(7), 730-737.

Bowers, M., Zhang, B., Ho, Y., Agarwal, P., Chen, C. C. \& Bhatia, R. (2015). Osteoblast ablation reduces normal long-term hematopoietic stem cell self-renewal but accelerates leukemia development. Blood, 125(17), 2678-2688.

Braess, J., Voss, S., Jahns-Streubel, G., Schoch, C., Haferlach, T., Kern, W., . . Hiddemann, W. (2000). The pharmacodynamic basis for the increased antileukaemic efficacy of cytosine arabinoside-based treatment regimens in acute myeloid leukaemia with a high proliferative activity. Br J Haematol, 110(1), 170-179.

Brand, M. D. (2010). The sites and topology of mitochondrial superoxide production. Exp Gerontol, 45(7-8), 466-472.

Breitenbuecher, F., Markova, B., Kasper, S., Carius, B., Stauder, T., Bohmer, F. D., . . F Fischer, T. (2009). A novel molecular mechanism of primary resistance to FLT3-kinase inhibitors in AML. Blood, 113(17), 4063-4073.

Briddell, R. A., Broudy, V. C., Bruno, E., Brandt, J. E., Srour, E. F. \& Hoffman, R. (1992). Further phenotypic characterization and isolation of human hematopoietic progenitor cells using a monoclonal antibody to the c-kit receptor. Blood, 79(12), 3159-3167.

Bruick, R. K. \& McKnight, S. L. (2001). A conserved family of prolyl-4-hydroxylases that modify HIF. Science, 294(5545), 1337-1340.

Brunet, A., Bonni, A., Zigmond, M. J., Lin, M. Z., Juo, P., Hu, L. S., . . Greenberg, M. E. (1999). Akt promotes cell survival by phosphorylating and inhibiting a Forkhead transcription factor. Cell, 96(6), 857-868.

Burger, H., van Tol, H., Brok, M., Wiemer, E. A., de Bruijn, E. A., Guetens, G., . . Nooter, K. (2005). Chronic imatinib mesylate exposure leads to reduced intracellular drug accumulation by induction of the ABCG2 (BCRP) and ABCB1 (MDR1) drug transport pumps. Cancer Biol Ther, 4(7), 747-752.

Buss, H., Dorrie, A., Schmitz, M. L., Hoffmann, E., Resch, K. \& Kracht, M. (2004). Constitutive and interleukin-1-inducible phosphorylation of p65 NF- $\{$ kappa $\} \mathrm{B}$ at serine 536 is mediated by multiple protein kinases including I $\{$ kappa\}B kinase (IKK)- $\{$ alpha $\}$, IKK $\{$ beta $\}$, IKK \{epsilon\}, TRAF family member-associated (TANK)-binding kinase 1 (TBK1), and an unknown kinase and couples p65 to TATA-binding protein-associated factor II31-mediated interleukin-8 transcription. J Biol Chem, 279(53), 55633-55643.

Bustelo, X. R., Rubin, S. D., Suen, K. L., Carrasco, D. \& Barbacid, M. (1993). Developmental expression of the vav protooncogene. Cell Growth Differ, 4(4), 297-308.

Calvi, L. M., Adams, G. B., Weibrecht, K. W., Weber, J. M., Olson, D. P., Knight, M. C., . . S Scadden, D. T. (2003). Osteoblastic cells regulate the haematopoietic stem cell niche. Nature, 425(6960), 841-846.

Cancer Genome Atlas Research, N., Ley, T. J., Miller, C., Ding, L., Raphael, B. J., Mungall, A. J., . . . Eley, G. (2013). Genomic and epigenomic landscapes of adult de novo acute myeloid leukemia. $N$ Engl J Med, 368(22), 2059-2074.

Case, S. S., Price, M. A., Jordan, C. T., Yu, X. J., Wang, L., Bauer, G., . . Crooks, G. M. (1999). Stable transduction of quiescent CD34(+)CD38(-) human hematopoietic cells by HIV-1-based lentiviral vectors. Proc Natl Acad Sci U S A, 96(6), 2988-2993.

Cau, S. B., Carneiro, F. S. \& Tostes, R. C. (2012). Differential modulation of nitric oxide synthases in aging: therapeutic opportunities. Front Physiol, 3, 218.

Ceradini, D. J., Kulkarni, A. R., Callaghan, M. J., Tepper, O. M., Bastidas, N., Kleinman, M. E., . . . Gurtner, G. C. (2004). Progenitor cell trafficking is regulated by hypoxic gradients through HIF-1 induction of SDF-1. Nat Med, 10(8), 858-864.

Challen, G. A., Boles, N., Lin, K. K. \& Goodell, M. A. (2009). Mouse hematopoietic stem cell identification and analysis. Cytometry A, 75(1), 14-24. 
Challen, G. A., Boles, N. C., Chambers, S. M. \& Goodell, M. A. (2010). Distinct hematopoietic stem cell subtypes are differentially regulated by TGF-beta1. Cell Stem Cell, 6(3), 265-278.

Chambers, S. M., Shaw, C. A., Gatza, C., Fisk, C. J., Donehower, L. A. \& Goodell, M. A. (2007). Aging hematopoietic stem cells decline in function and exhibit epigenetic dysregulation. PLoS Biol, 5(8), e201.

Chen, C., Liu, Y., Liu, R., Ikenoue, T., Guan, K. L., Liu, Y. \& Zheng, P. (2008). TSC-mTOR maintains quiescence and function of hematopoietic stem cells by repressing mitochondrial biogenesis and reactive oxygen species. J Exp Med, 205(10), 2397-2408.

Chen, J. Y., Miyanishi, M., Wang, S. K., Yamazaki, S., Sinha, R., Kao, K. S., . . Weissman, I. L. (2016). Hoxb5 marks long-term haematopoietic stem cells and reveals a homogenous perivascular niche. Nature, 530(7589), 223-227.

Chen, L. F., Williams, S. A., Mu, Y., Nakano, H., Duerr, J. M., Buckbinder, L. \& Greene, W. C. (2005). NF-kappaB RelA phosphorylation regulates RelA acetylation. Mol Cell Biol, 25(18), 7966-7975.

Chow, D. C., Wenning, L. A., Miller, W. M. \& Papoutsakis, E. T. (2001). Modeling pO(2) distributions in the bone marrow hematopoietic compartment. II. Modified Kroghian models. Biophys J, 81(2), 685-696.

Chowdhury, R., McDonough, M. A., Mecinovic, J., Loenarz, C., Flashman, E., Hewitson, K. S., . . . Schofield, C. J. (2009). Structural basis for binding of hypoxia-inducible factor to the oxygensensing prolyl hydroxylases. Structure, 17(7), 981-989.

Christensen, J. L. \& Weissman, I. L. (2001). Flk-2 is a marker in hematopoietic stem cell differentiation: a simple method to isolate long-term stem cells. Proc Natl Acad Sci U S A, 98(25), 14541-14546.

Christian, F., Smith, E. L. \& Carmody, R. J. (2016). The Regulation of NF-kappaB Subunits by Phosphorylation. Cells, 5(1).

Christopher, M. J., Petti, A. A., Rettig, M. P., Miller, C. A., Chendamarai, E., Duncavage, E. J., . . . DiPersio, J. F. (2018). Immune Escape of Relapsed AML Cells after Allogeneic Transplantation. $N$ Engl J Med.

Cipolleschi, M. G., Dello Sbarba, P. \& Olivotto, M. (1993). The role of hypoxia in the maintenance of hematopoietic stem cells. Blood, 82(7), 2031-2037.

Collins, S. J., Gallo, R. C. \& Gallagher, R. E. (1977). Continuous growth and differentiation of human myeloid leukaemic cells in suspension culture. Nature, 270(5635), 347-349.

Comerford, K. M., Wallace, T. J., Karhausen, J., Louis, N. A., Montalto, M. C. \& Colgan, S. P. (2002). Hypoxia-inducible factor-1-dependent regulation of the multidrug resistance (MDR1) gene. Cancer Res, 62(12), 3387-3394.

Conneally, E., Cashman, J., Petzer, A. \& Eaves, C. (1997). Expansion in vitro of transplantable human cord blood stem cells demonstrated using a quantitative assay of their lympho-myeloid repopulating activity in nonobese diabetic-scid/scid mice. Proc Natl Acad Sci U S A, 94(18), 9836-9841.

Corbin, A. S., Agarwal, A., Loriaux, M., Cortes, J., Deininger, M. W. \& Druker, B. J. (2011). Human chronic myeloid leukemia stem cells are insensitive to imatinib despite inhibition of BCRABL activity. J Clin Invest, 121(1), 396-409.

Cortes, J. E., Saglio, G., Kantarjian, H. M., Baccarani, M., Mayer, J., Boque, C., . . . Hochhaus, A. (2016). Final 5-Year Study Results of DASISION: The Dasatinib Versus Imatinib Study in Treatment-Naive Chronic Myeloid Leukemia Patients Trial. J Clin Oncol, 34(20), 2333-2340.

Culver, C., Sundqvist, A., Mudie, S., Melvin, A., Xirodimas, D. \& Rocha, S. (2010). Mechanism of hypoxia-induced NF-kappaB. Mol Cell Biol, 30(20), 4901-4921.

Cummins, E. P., Berra, E., Comerford, K. M., Ginouves, A., Fitzgerald, K. T., Seeballuck, F., . . . Taylor, C. T. (2006). Prolyl hydroxylase-1 negatively regulates IkappaB kinase-beta, giving insight into hypoxia-induced NFkappaB activity. Proc Natl Acad Sci U S A, 103(48), 1815418159.

Danet, G. H., Pan, Y., Luongo, J. L., Bonnet, D. A. \& Simon, M. C. (2003). Expansion of human SCID-repopulating cells under hypoxic conditions. The Journal of clinical investigation, 112(1), 126-135. 
de Lima, M., McNiece, I., Robinson, S. N., Munsell, M., Eapen, M., Horowitz, M., . . Shpall, E. J. (2012). Cord-blood engraftment with ex vivo mesenchymal-cell coculture. $N$ Engl J Med, 367(24), 2305-2315.

Delaney, C., Heimfeld, S., Brashem-Stein, C., Voorhies, H., Manger, R. L. \& Bernstein, I. D. (2010). Notch-mediated expansion of human cord blood progenitor cells capable of rapid myeloid reconstitution. Nat Med, 16(2), 232-236.

Dengler, V. L., Galbraith, M. \& Espinosa, J. M. (2014). Transcriptional regulation by hypoxia inducible factors. Crit Rev Biochem Mol Biol, 49(1), 1-15.

Desplat, V., Faucher, J. L., Mahon, F. X., Dello Sbarba, P., Praloran, V. \& Ivanovic, Z. (2002). Hypoxia modifies proliferation and differentiation of CD34(+) CML cells. Stem Cells, 20(4), 347-354.

Dexter, T. M. (1984). Blood cell development. The message in the medium. Nature, 309(5971), 746747.

DiDonato, J. A., Hayakawa, M., Rothwarf, D. M., Zandi, E. \& Karin, M. (1997). A cytokineresponsive IkappaB kinase that activates the transcription factor NF-kappaB. Nature, 388(6642), 548-554.

Ding, L., Ley, T. J., Larson, D. E., Miller, C. A., Koboldt, D. C., Welch, J. S., . . DiPersio, J. F. (2012a). Clonal evolution in relapsed acute myeloid leukaemia revealed by whole-genome sequencing. Nature, 481(7382), 506-510.

Ding, L. \& Morrison, S. J. (2013). Haematopoietic stem cells and early lymphoid progenitors occupy distinct bone marrow niches. Nature, 495(7440), 231-235.

Ding, L., Saunders, T. L., Enikolopov, G. \& Morrison, S. J. (2012b). Endothelial and perivascular cells maintain haematopoietic stem cells. Nature, 481(7382), 457-462.

Dinkova-Kostova, A. T., Holtzclaw, W. D., Cole, R. N., Itoh, K., Wakabayashi, N., Katoh, Y., ... . Talalay, P. (2002). Direct evidence that sulfhydryl groups of Keap1 are the sensors regulating induction of phase 2 enzymes that protect against carcinogens and oxidants. Proc Natl Acad Sci U S A, 99(18), 11908-11913.

Discher, D. E., Mooney, D. J. \& Zandstra, P. W. (2009). Growth factors, matrices, and forces combine and control stem cells. Science, 324(5935), 1673-1677.

Dohner, H., Estey, E. H., Amadori, S., Appelbaum, F. R., Buchner, T., Burnett, A. K., . . European, L. (2010). Diagnosis and management of acute myeloid leukemia in adults: recommendations from an international expert panel, on behalf of the European LeukemiaNet. Blood, 115(3), 453-474.

Dohner, H., Weisdorf, D. J. \& Bloomfield, C. D. (2015). Acute Myeloid Leukemia. N Engl J Med, 373(12), 1136-1152.

Droge, W. (2002). Free radicals in the physiological control of cell function. Physiol Rev, 82(1), 47-95.

Drolle, H., Wagner, M., Vasold, J., Kutt, A., Deniffel, C., Sotlar, K., . . . Fiegl, M. (2015). Hypoxia regulates proliferation of acute myeloid leukemia and sensitivity against chemotherapy. Leuk Res, 39(7), 779-785.

Du, J., Li, Q., Tang, F., Puchowitz, M. A., Fujioka, H., Dunwoodie, S. L., . . Yang, Y. C. (2014). Cited 2 is required for the maintenance of glycolytic metabolism in adult hematopoietic stem cells. Stem Cells Dev, 23(2), 83-94.

Dykstra, B., Olthof, S., Schreuder, J., Ritsema, M. \& de Haan, G. (2011). Clonal analysis reveals multiple functional defects of aged murine hematopoietic stem cells. J Exp Med, 208(13), 2691-2703.

Dykstra, B., Ramunas, J., Kent, D., McCaffrey, L., Szumsky, E., Kelly, L., . . Jervis, E. (2006). Highresolution video monitoring of hematopoietic stem cells cultured in single-cell arrays identifies new features of self-renewal. Proc Natl Acad Sci U S A, 103(21), 8185-8190.

Eadie, L. N., Dang, P., Saunders, V. A., Yeung, D. T., Osborn, M. P., Grigg, A. P., . . White, D. L. (2017). The clinical significance of ABCB1 overexpression in predicting outcome of CML patients undergoing first-line imatinib treatment. Leukemia, 31(1), 75-82.

Ebert, B. L. \& Bunn, H. F. (1998). Regulation of transcription by hypoxia requires a multiprotein complex that includes hypoxia-inducible factor 1 , an adjacent transcription factor, and p300/CREB binding protein. Mol Cell Biol, 18(7), 4089-4096. 
Eliasson, P. \& Jönsson, J. I. (2010). The hematopoietic stem cell niche: low in oxygen but a nice place to be. Journal of cellular physiology, 222(1), 17-22.

Eliasson, P., Rehn, M., Hammar, P., Larsson, P., Sirenko, O., Flippin, L. A., . . Jönsson, J. I. (2010). Hypoxia mediates low cell-cycle activity and increases the proportion of long-termreconstituting hematopoietic stem cells during in vitro culture. Exp Hematol, 38(4), 301-310 e302.

Elvidge, G. P., Glenny, L., Appelhoff, R. J., Ratcliffe, P. J., Ragoussis, J. \& Gleadle, J. M. (2006). Concordant regulation of gene expression by hypoxia and 2-oxoglutarate-dependent dioxygenase inhibition: the role of HIF-1alpha, HIF-2alpha, and other pathways. J Biol Chem, 281(22), 15215-15226.

Ema, H., Morita, Y. \& Suda, T. (2014). Heterogeneity and hierarchy of hematopoietic stem cells. Exp Hematol, 42(2), 74-82 e72.

Ema, H., Morita, Y., Yamazaki, S., Matsubara, A., Seita, J., Tadokoro, Y., . . Nakauchi, H. (2006). Adult mouse hematopoietic stem cells: purification and single-cell assays. Nature protocols, l(6), 2979-2987.

Ema, H., Sudo, K., Seita, J., Matsubara, A., Morita, Y., Osawa, M., . . . Nakauchi, H. (2005). Quantification of self-renewal capacity in single hematopoietic stem cells from normal and Lnk-deficient mice. Dev Cell, 8(6), 907-914.

Ema, M., Hirota, K., Mimura, J., Abe, H., Yodoi, J., Sogawa, K., . . . Fujii-Kuriyama, Y. (1999). Molecular mechanisms of transcription activation by HLF and HIF1alpha in response to hypoxia: their stabilization and redox signal-induced interaction with $\mathrm{CBP} / \mathrm{p} 300$. EMBO J, 18(7), 1905-1914.

Fares, I., Chagraoui, J., Gareau, Y., Gingras, S., Ruel, R., Mayotte, N., . . Sauvageau, G. (2014). Cord blood expansion. Pyrimidoindole derivatives are agonists of human hematopoietic stem cell self-renewal. Science, 345(6203), 1509-1512.

Fei, P., Wang, W., Kim, S. H., Wang, S., Burns, T. F., Sax, J. K., . . El-Deiry, W. S. (2004). Bnip3L is induced by p53 under hypoxia, and its knockdown promotes tumor growth. Cancer Cell, 6(6), 597-609.

Feng, Q., Chai, C., Jiang, X. S., Leong, K. W. \& Mao, H. Q. (2006). Expansion of engrafting human hematopoietic stem/progenitor cells in three-dimensional scaffolds with surface-immobilized fibronectin. J Biomed Mater Res A, 78(4), 781-791.

Ferlay, J., Soerjomataram, I., Dikshit, R., Eser, S., Mathers, C., Rebelo, M., . . . Bray, F. (2015). Cancer incidence and mortality worldwide: sources, methods and major patterns in GLOBOCAN 2012. Int J Cancer, 136(5), E359-386.

Ferrando, A. A. \& Lopez-Otin, C. (2017). Clonal evolution in leukemia. Nat Med, 23(10), 1135-1145.

Fox, N., Priestley, G., Papayannopoulou, T. \& Kaushansky, K. (2002). Thrombopoietin expands hematopoietic stem cells after transplantation. J Clin Invest, 110(3), 389-394.

Frenette, P. S., Pinho, S., Lucas, D. \& Scheiermann, C. (2013). Mesenchymal stem cell: keystone of the hematopoietic stem cell niche and a stepping-stone for regenerative medicine. Annu Rev Immunol, 31, 285-316.

Frisch, B. J. \& Calvi, L. M. (2014). Hematopoietic stem cell cultures and assays. Methods Mol Biol, 1130, 315-324.

Furlow, P. W., Percy, M. J., Sutherland, S., Bierl, C., McMullin, M. F., Master, S. R., . . Lee, F. S. (2009). Erythrocytosis-associated HIF-2alpha mutations demonstrate a critical role for residues C-terminal to the hydroxylacceptor proline. J Biol Chem, 284(14), 9050-9058.

Furukawa, M. \& Xiong, Y. (2005). BTB protein Keap1 targets antioxidant transcription factor Nrf2 for ubiquitination by the Cullin 3-Roc1 ligase. Mol Cell Biol, 25(1), 162-171.

Gammaitoni, L., Bruno, S., Sanavio, F., Gunetti, M., Kollet, O., Cavalloni, G., . . . Piacibello, W. (2003). Ex vivo expansion of human adult stem cells capable of primary and secondary hemopoietic reconstitution. Exp Hematol, 31(3), 261-270.

Gattazzo, F., Urciuolo, A. \& Bonaldo, P. (2014). Extracellular matrix: a dynamic microenvironment for stem cell niche. Biochim Biophys Acta, 1840(8), 2506-2519.

Genovese, G., Kahler, A. K., Handsaker, R. E., Lindberg, J., Rose, S. A., Bakhoum, S. F., . . . McCarroll, S. A. (2014). Clonal hematopoiesis and blood-cancer risk inferred from blood DNA sequence. $N$ Engl J Med, 371(26), 2477-2487. 
Gilliland, D. G. \& Griffin, J. D. (2002). The roles of FLT3 in hematopoiesis and leukemia. Blood, 100(5), 1532-1542.

Gilmore, T. D. (2006). Introduction to NF-kappaB: players, pathways, perspectives. Oncogene, 25(51), 6680-6684.

Giuntoli, S., Rovida, E., Barbetti, V., Cipolleschi, M. G., Olivotto, M. \& Dello Sbarba, P. (2006). Hypoxia suppresses BCR/Abl and selects imatinib-insensitive progenitors within clonal CML populations. Leukemia, 20(7), 1291-1293.

Giuntoli, S., Tanturli, M., Di Gesualdo, F., Barbetti, V., Rovida, E. \& Dello Sbarba, P. (2011). Glucose availability in hypoxia regulates the selection of chronic myeloid leukemia progenitor subsets with different resistance to imatinib-mesylate. Haematologica, 96(2), 204-212.

Glimm, H., Eisterer, W., Lee, K., Cashman, J., Holyoake, T. L., Nicolini, F., . . Eaves, C. J. (2001). Previously undetected human hematopoietic cell populations with short-term repopulating activity selectively engraft NOD/SCID-beta2 microglobulin-null mice. J Clin Invest, 107(2), 199-206.

Goardon, N., Marchi, E., Atzberger, A., Quek, L., Schuh, A., Soneji, S., . . . Vyas, P. (2011). Coexistence of LMPP-like and GMP-like leukemia stem cells in acute myeloid leukemia. Cancer Cell, 19(1), 138-152.

Goldberg, M. A., Dunning, S. P. \& Bunn, H. F. (1988). Regulation of the erythropoietin gene: evidence that the oxygen sensor is a heme protein. Science, 242(4884), 1412-1415.

Goodell, M. A., Brose, K., Paradis, G., Conner, A. S. \& Mulligan, R. C. (1996). Isolation and functional properties of murine hematopoietic stem cells that are replicating in vivo. $J$ Exp Med, 183(4), 1797-1806.

Gordan, J. D., Bertout, J. A., Hu, C. J., Diehl, J. A. \& Simon, M. C. (2007). HIF-2alpha promotes hypoxic cell proliferation by enhancing c-myc transcriptional activity. Cancer Cell, 11(4), 335-347.

Graham, S. M., Jorgensen, H. G., Allan, E., Pearson, C., Alcorn, M. J., Richmond, L. \& Holyoake, T. L. (2002). Primitive, quiescent, Philadelphia-positive stem cells from patients with chronic myeloid leukemia are insensitive to STI571 in vitro. Blood, 99(1), 319-325.

Greenbaum, A., Hsu, Y. M., Day, R. B., Schuettpelz, L. G., Christopher, M. J., Borgerding, J. N., . . . Link, D. C. (2013). CXCL12 in early mesenchymal progenitors is required for haematopoietic stem-cell maintenance. Nature, 495(7440), 227-230.

Griffith, O. W. (1982). Mechanism of action, metabolism, and toxicity of buthionine sulfoximine and its higher homologs, potent inhibitors of glutathione synthesis. J Biol Chem, 257(22), 1370413712.

Grove, C. S. \& Vassiliou, G. S. (2014). Acute myeloid leukaemia: a paradigm for the clonal evolution of cancer? Dis Model Mech, 7(8), 941-951.

Grundler, R., Thiede, C., Miething, C., Steudel, C., Peschel, C. \& Duyster, J. (2003). Sensitivity toward tyrosine kinase inhibitors varies between different activating mutations of the FLT3 receptor. Blood, 102(2), 646-651.

Guan, Y., Gerhard, B. \& Hogge, D. E. (2003). Detection, isolation, and stimulation of quiescent primitive leukemic progenitor cells from patients with acute myeloid leukemia (AML). Blood, 101(8), 3142-3149.

Guitart, A. V., Hammoud, M., Dello Sbarba, P., Ivanovic, Z. \& Praloran, V. (2010). Slowcycling/quiescence balance of hematopoietic stem cells is related to physiological gradient of oxygen. Experimental hematology, 38(10), 847-851.

Guitart, A. V., Subramani, C., Armesilla-Diaz, A., Smith, G., Sepulveda, C., Gezer, D., . . Kranc, K. R. (2013). Hif-2alpha is not essential for cell-autonomous hematopoietic stem cell maintenance. Blood, 122(10), 1741-1745.

Halvarsson, C., Eliasson, P. \& Jönsson, J. I. (2017). Pyruvate dehydrogenase kinase 1 is essential for transplantable mouse bone marrow hematopoietic stem cell and progenitor function. PLoS One, 12(2), e0171714.

Hammond, E. M., Mandell, D. J., Salim, A., Krieg, A. J., Johnson, T. M., Shirazi, H. A., . . Giaccia, A. J. (2006). Genome-wide analysis of p53 under hypoxic conditions. Mol Cell Biol, 26(9), 3492-3504. 
Harrison, J. S., Rameshwar, P., Chang, V. \& Bandari, P. (2002). Oxygen saturation in the bone marrow of healthy volunteers. Blood, 99(1), 394.

Hayden, M. S. \& Ghosh, S. (2004). Signaling to NF-kappaB. Genes Dev, 18(18), 2195-2224.

Heidel, F., Solem, F. K., Breitenbuecher, F., Lipka, D. B., Kasper, S., Thiede, M. H., . . F Fischer, T. (2006). Clinical resistance to the kinase inhibitor PKC412 in acute myeloid leukemia by mutation of Asn-676 in the FLT3 tyrosine kinase domain. Blood, 107(1), 293-300.

Heinrich, P. C., Behrmann, I., Haan, S., Hermanns, H. M., Muller-Newen, G. \& Schaper, F. (2003). Principles of interleukin (IL)-6-type cytokine signalling and its regulation. Biochem J, 374(Pt 1), 1-20.

Hermitte, F., Brunet de la Grange, P., Belloc, F., Praloran, V. \& Ivanovic, Z. (2006). Very low O2 concentration $(0.1 \%)$ favors G0 return of dividing CD34+ cells. Stem Cells, 24(1), 65-73.

Hinz, M. \& Scheidereit, C. (2014). The IkappaB kinase complex in NF-kappaB regulation and beyond. EMBO Rep, 15(1), 46-61.

Hochhaus, A., Kantarjian, H. M., Baccarani, M., Lipton, J. H., Apperley, J. F., Druker, B. J., . . Shah, N. P. (2007). Dasatinib induces notable hematologic and cytogenetic responses in chronicphase chronic myeloid leukemia after failure of imatinib therapy. Blood, 109(6), 2303-2309.

Hochhaus, A., Saglio, G., Hughes, T. P., Larson, R. A., Kim, D. W., Issaragrisil, S., . . Kantarjian, H. M. (2016). Long-term benefits and risks of frontline nilotinib vs imatinib for chronic myeloid leukemia in chronic phase: 5-year update of the randomized ENESTnd trial. Leukemia, 30(5), 1044-1054.

Holmstrom, K. M. \& Finkel, T. (2014). Cellular mechanisms and physiological consequences of redox-dependent signalling. Nat Rev Mol Cell Biol, 15(6), 411-421.

Hu, C. J., Sataur, A., Wang, L., Chen, H. \& Simon, M. C. (2007). The N-terminal transactivation domain confers target gene specificity of hypoxia-inducible factors HIF-1alpha and HIF2alpha. Mol Biol Cell, 18(11), 4528-4542.

Hu, C. J., Wang, L. Y., Chodosh, L. A., Keith, B. \& Simon, M. C. (2003). Differential roles of hypoxia-inducible factor 1alpha (HIF-1alpha) and HIF-2alpha in hypoxic gene regulation. Mol Cell Biol, 23(24), 9361-9374.

Huntly, B. J. \& Gilliland, D. G. (2005). Cancer biology: summing up cancer stem cells. Nature, 435(7046), 1169-1170.

Ikuta, K. \& Weissman, I. L. (1992). Evidence that hematopoietic stem cells express mouse c-kit but do not depend on steel factor for their generation. Proceedings of the National Academy of Sciences of the United States of America, 89(4), 1502-1506.

Ishikawa, F., Yoshida, S., Saito, Y., Hijikata, A., Kitamura, H., Tanaka, S., . . Shultz, L. D. (2007). Chemotherapy-resistant human AML stem cells home to and engraft within the bone-marrow endosteal region. Nat Biotechnol, 25(11), 1315-1321.

Itkin, T., Gur-Cohen, S., Spencer, J. A., Schajnovitz, A., Ramasamy, S. K., Kusumbe, A. P., . . . Lapidot, T. (2016). Distinct bone marrow blood vessels differentially regulate haematopoiesis. Nature, 532(7599), 323-328.

Ito, K., Hirao, A., Arai, F., Matsuoka, S., Takubo, K., Hamaguchi, I., . . Suda, T. (2004). Regulation of oxidative stress by ATM is required for self-renewal of haematopoietic stem cells. Nature, 431(7011), 997-1002.

Ito, K., Hirao, A., Arai, F., Takubo, K., Matsuoka, S., Miyamoto, K., . . Suda, T. (2006). Reactive oxygen species act through p38 MAPK to limit the lifespan of hematopoietic stem cells. Nat Med, 12(4), 446-451.

Ito, K. \& Suda, T. (2014). Metabolic requirements for the maintenance of self-renewing stem cells. Nat Rev Mol Cell Biol, 15(4), 243-256.

Ito, S., Barrett, A. J., Dutra, A., Pak, E., Miner, S., Keyvanfar, K., . . Melenhorst, J. J. (2015). Long term maintenance of myeloid leukemic stem cells cultured with unrelated human mesenchymal stromal cells. Stem Cell Res, 14(1), 95-104.

Itoh, K., Chiba, T., Takahashi, S., Ishii, T., Igarashi, K., Katoh, Y., . . Nabeshima, Y. (1997). An Nrf2/small Maf heterodimer mediates the induction of phase II detoxifying enzyme genes through antioxidant response elements. Biochem Biophys Res Commun, 236(2), 313-322. 
Itoh, K., Wakabayashi, N., Katoh, Y., Ishii, T., Igarashi, K., Engel, J. D. \& Yamamoto, M. (1999). Keap1 represses nuclear activation of antioxidant responsive elements by Nrf2 through binding to the amino-terminal Neh2 domain. Genes Dev, 13(1), 76-86.

Ivan, M., Kondo, K., Yang, H., Kim, W., Valiando, J., Ohh, M., . . Kaelin, W. G., Jr. (2001). HIFalpha targeted for VHL-mediated destruction by proline hydroxylation: implications for O2 sensing. Science, 292(5516), 464-468.

Ivanovic, Z., Bartolozzi, B., Bernabei, P. A., Cipolleschi, M. G., Rovida, E., Milenkovic, P., . . Dello Sbarba, P. (2000). Incubation of murine bone marrow cells in hypoxia ensures the maintenance of marrow-repopulating ability together with the expansion of committed progenitors. Br J Haematol, 108(2), 424-429.

Ivanovic, Z., Belloc, F., Faucher, J. L., Cipolleschi, M. G., Praloran, V. \& Dello Sbarba, P. (2002). Hypoxia maintains and interleukin-3 reduces the pre-colony-forming cell potential of dividing CD34(+) murine bone marrow cells. Exp Hematol, 30(1), 67-73.

Ivanovic, Z., Hermitte, F., Brunet de la Grange, P., Dazey, B., Belloc, F., Lacombe, F., . . Praloran, V. (2004). Simultaneous maintenance of human cord blood SCID-repopulating cells and expansion of committed progenitors at low O2 concentration (3\%). Stem Cells, 22(5), 716-724.

Jaakkola, P., Mole, D. R., Tian, Y. M., Wilson, M. I., Gielbert, J., Gaskell, S. J., . . Ratcliffe, P. J. (2001). Targeting of HIF-alpha to the von Hippel-Lindau ubiquitylation complex by O2regulated prolyl hydroxylation. Science, 292(5516), 468-472.

Jabbour, E., Cortes, J., Ravandi, F., O'Brien, S. \& Kantarjian, H. (2013). Targeted therapies in hematology and their impact on patient care: chronic and acute myeloid leukemia. Semin Hematol, 50(4), 271-283.

Jaiswal, S., Fontanillas, P., Flannick, J., Manning, A., Grauman, P. V., Mar, B. G., . . Ebert, B. L. (2014). Age-related clonal hematopoiesis associated with adverse outcomes. $N$ Engl J Med, $371(26), 2488-2498$.

Jan, M., Snyder, T. M., Corces-Zimmerman, M. R., Vyas, P., Weissman, I. L., Quake, S. R. \& Majeti, R. (2012). Clonal evolution of preleukemic hematopoietic stem cells precedes human acute myeloid leukemia. Sci Transl Med, 4(149), 149ra118.

Jang, Y. Y. \& Sharkis, S. J. (2007). A low level of reactive oxygen species selects for primitive hematopoietic stem cells that may reside in the low-oxygenic niche. Blood, 110(8), 3056-3063.

Jiang, B. H., Semenza, G. L., Bauer, C. \& Marti, H. H. (1996). Hypoxia-inducible factor 1 levels vary exponentially over a physiologically relevant range of $\mathrm{O} 2$ tension. The American journal of physiology, 271(4 Pt 1), C1172-1180.

Jin, L., Tabe, Y., Konoplev, S., Xu, Y., Leysath, C. E., Lu, H., . . Konopleva, M. (2008). CXCR4 upregulation by imatinib induces chronic myelogenous leukemia (CML) cell migration to bone marrow stroma and promotes survival of quiescent CML cells. Mol Cancer Ther, 7(1), 48-58.

Jing, D., Fonseca, A. V., Alakel, N., Fierro, F. A., Muller, K., Bornhauser, M., . . . Ordemann, R. (2010). Hematopoietic stem cells in co-culture with mesenchymal stromal cells--modeling the niche compartments in vitro. Haematologica, 95(4), 542-550.

Jung, Y., Wang, J., Schneider, A., Sun, Y. X., Koh-Paige, A. J., Osman, N. I., . . . Taichman, R. S. (2006). Regulation of SDF-1 (CXCL12) production by osteoblasts; a possible mechanism for stem cell homing. Bone, 38(4), 497-508.

Juntilla, M. M., Patil, V. D., Calamito, M., Joshi, R. P., Birnbaum, M. J. \& Koretzky, G. A. (2010). AKT1 and AKT2 maintain hematopoietic stem cell function by regulating reactive oxygen species. Blood, 115(20), 4030-4038.

Kaelin, W. G., Jr. \& Ratcliffe, P. J. (2008). Oxygen sensing by metazoans: the central role of the HIF hydroxylase pathway. Mol Cell, 30(4), 393-402.

Kallio, P. J., Pongratz, I., Gradin, K., McGuire, J. \& Poellinger, L. (1997). Activation of hypoxiainducible factor 1alpha: posttranscriptional regulation and conformational change by recruitment of the Arnt transcription factor. Proc Natl Acad Sci U S A, 94(11), 5667-5672.

Kanda, T., Sullivan, K. F. \& Wahl, G. M. (1998). Histone-GFP fusion protein enables sensitive analysis of chromosome dynamics in living mammalian cells. Curr Biol, 8(7), 377-385.

Kantarjian, H., Sawyers, C., Hochhaus, A., Guilhot, F., Schiffer, C., Gambacorti-Passerini, C., . . . International, S. T. I. C. M. L. S. G. (2002). Hematologic and cytogenetic responses to imatinib mesylate in chronic myelogenous leukemia. $N$ Engl J Med, 346(9), 645-652. 
Kantarjian, H. M., Giles, F., Gattermann, N., Bhalla, K., Alimena, G., Palandri, F., . . . le Coutre, P. (2007). Nilotinib (formerly AMN107), a highly selective BCR-ABL tyrosine kinase inhibitor, is effective in patients with Philadelphia chromosome-positive chronic myelogenous leukemia in chronic phase following imatinib resistance and intolerance. Blood, 110(10), 3540-3546.

Kapp, F. G., Perlin, J. R., Hagedorn, E. J., Gansner, J. M., Schwarz, D. E., O'Connell, L. A., . . Zon, L. I. (2018). Protection from UV light is an evolutionarily conserved feature of the haematopoietic niche. Nature, 558(7710), 445-448.

Kastan, M. B. (2008). DNA damage responses: mechanisms and roles in human disease: 2007 G.H.A. Clowes Memorial Award Lecture. Mol Cancer Res, 6(4), 517-524.

Kato, T., Jr., Delhase, M., Hoffmann, A. \& Karin, M. (2003). CK2 Is a C-Terminal IkappaB Kinase Responsible for NF-kappaB Activation during the UV Response. Mol Cell, 12(4), 829-839.

Kaushansky, K. (2005). The molecular mechanisms that control thrombopoiesis. J Clin Invest, 115(12), 3339-3347.

Ke, Q. \& Costa, M. (2006). Hypoxia-inducible factor-1 (HIF-1). Mol Pharmacol, 70(5), 1469-1480.

Kent, D., Dykstra, B. \& Eaves, C. (2007). Isolation and assessment of long-term reconstituting hematopoietic stem cells from adult mouse bone marrow. Curr Protoc Stem Cell Biol, Chapter 2, Unit 2A 4.

Kertesz, Z., Vas, V., Kiss, J., Urban, V. S., Pozsonyi, E., Kozma, A., . . Uher, F. (2006). In vitro expansion of long-term repopulating hematopoietic stem cells in the presence of immobilized Jagged-1 and early acting cytokines. Cell Biol Int, 30(5), 401-405.

Kharas, M. G., Okabe, R., Ganis, J. J., Gozo, M., Khandan, T., Paktinat, M., . . Gritsman, K. (2010). Constitutively active AKT depletes hematopoietic stem cells and induces leukemia in mice. Blood, 115(7), 1406-1415.

Kiel, M. J. \& Morrison, S. J. (2008). Uncertainty in the niches that maintain haematopoietic stem cells. Nature reviews. Immunology, 8(4), 290-301.

Kiel, M. J., Yilmaz, O. H., Iwashita, T., Yilmaz, O. H., Terhorst, C. \& Morrison, S. J. (2005). SLAM family receptors distinguish hematopoietic stem and progenitor cells and reveal endothelial niches for stem cells. Cell, 121(7), 1109-1121.

Kim, K. T., Baird, K., Ahn, J. Y., Meltzer, P., Lilly, M., Levis, M. \& Small, D. (2005). Pim-1 is upregulated by constitutively activated FLT3 and plays a role in FLT3-mediated cell survival. Blood, 105(4), 1759-1767.

Kimura, S., Roberts, A. W., Metcalf, D. \& Alexander, W. S. (1998). Hematopoietic stem cell deficiencies in mice lacking c-Mpl, the receptor for thrombopoietin. Proc Natl Acad Sci U S A, 95(3), 1195-1200.

Kishi, K., Takahashi, M., Aoki, S., Nagai, K., Hirosawa, H., Koike, T., . . et al. (1984). [A new Ph1 positive cell line (KU812) from a patient with blastic crisis of chronic myelogenous leukemia]. Nihon Ketsueki Gakkai Zasshi, 47(3), 709-718.

Kohl, T. M., Hellinger, C., Ahmed, F., Buske, C., Hiddemann, W., Bohlander, S. K. \& Spiekermann, K. (2007). BH3 mimetic ABT-737 neutralizes resistance to FLT3 inhibitor treatment mediated by FLT3-independent expression of BCL2 in primary AML blasts. Leukemia, 21(8), 17631772.

Kondo, M., Weissman, I. L. \& Akashi, K. (1997). Identification of clonogenic common lymphoid progenitors in mouse bone marrow. Cell, 91(5), 661-672.

Konig, H. \& Levis, M. (2015). Targeting FLT3 to treat leukemia. Expert Opin Ther Targets, 19(1), 37-54.

Konopleva, M. Y. \& Jordan, C. T. (2011). Leukemia stem cells and microenvironment: biology and therapeutic targeting. J Clin Oncol, 29(5), 591-599.

Koong, A. C., Chen, E. Y. \& Giaccia, A. J. (1994). Hypoxia causes the activation of nuclear factor kappa B through the phosphorylation of I kappa B alpha on tyrosine residues. Cancer Res, 54(6), 1425-1430.

Koshiji, M., Kageyama, Y., Pete, E. A., Horikawa, I., Barrett, J. C. \& Huang, L. E. (2004). HIF-1alpha induces cell cycle arrest by functionally counteracting Myc. EMBO J, 23(9), 1949-1956.

Kothari, A., Hittelman, W. N. \& Chambers, T. C. (2016). Cell Cycle-Dependent Mechanisms Underlie Vincristine-Induced Death of Primary Acute Lymphoblastic Leukemia Cells. Cancer Res, 76(12), 3553-3561. 
Koumenis, C., Alarcon, R., Hammond, E., Sutphin, P., Hoffman, W., Murphy, M., . . G Giaccia, A. (2001). Regulation of p53 by hypoxia: dissociation of transcriptional repression and apoptosis from p53-dependent transactivation. Mol Cell Biol, 21(4), 1297-1310.

Koyasu, S., Kobayashi, M., Goto, Y., Hiraoka, M. \& Harada, H. (2018). Regulatory mechanisms of hypoxia-inducible factor 1 activity: Two decades of knowledge. Cancer Sci, 109(3), 560-571.

Krivtsov, A. V., Twomey, D., Feng, Z., Stubbs, M. C., Wang, Y., Faber, J., . . . Armstrong, S. A. (2006). Transformation from committed progenitor to leukaemia stem cell initiated by MLLAF9. Nature, 442(7104), 818-822.

Krock, B. L., Eisinger-Mathason, T. S., Giannoukos, D. N., Shay, J. E., Gohil, M., Lee, D. S., . . . Simon, M. C. (2015). The aryl hydrocarbon receptor nuclear translocator is an essential regulator of murine hematopoietic stem cell viability. Blood, 125(21), 3263-3272.

Kubonishi, I. \& Miyoshi, I. (1983). Establishment of a Ph1 chromosome-positive cell line from chronic myelogenous leukemia in blast crisis. Int J Cell Cloning, 1(2), 105-117.

Kuhn, R., Schwenk, F., Aguet, M. \& Rajewsky, K. (1995). Inducible gene targeting in mice. Science, 269(5229), 1427-1429.

Kunisaki, Y., Bruns, I., Scheiermann, C., Ahmed, J., Pinho, S., Zhang, D., . . Frenette, P. S. (2013). Arteriolar niches maintain haematopoietic stem cell quiescence. Nature, 502(7473), 637-643.

Lando, D., Peet, D. J., Whelan, D. A., Gorman, J. J. \& Whitelaw, M. L. (2002). Asparagine hydroxylation of the HIF transactivation domain a hypoxic switch. Science, 295(5556), 858861.

Lapidot, T., Sirard, C., Vormoor, J., Murdoch, B., Hoang, T., Caceres-Cortes, J., . . Dick, J. E. (1994). A cell initiating human acute myeloid leukaemia after transplantation into SCID mice. Nature, 367(6464), 645-648.

Larochelle, A., Savona, M., Wiggins, M., Anderson, S., Ichwan, B., Keyvanfar, K., . . Dunbar, C. E. (2011). Human and rhesus macaque hematopoietic stem cells cannot be purified based only on SLAM family markers. Blood, 117(5), 1550-1554.

Lawrence, M. S., Stojanov, P., Polak, P., Kryukov, G. V., Cibulskis, K., Sivachenko, A., . . Getz, G. (2013). Mutational heterogeneity in cancer and the search for new cancer-associated genes. Nature, 499(7457), 214-218.

Lee, K., Qian, D. Z., Rey, S., Wei, H., Liu, J. O. \& Semenza, G. L. (2009). Anthracycline chemotherapy inhibits HIF-1 transcriptional activity and tumor-induced mobilization of circulating angiogenic cells. Proc Natl Acad Sci U S A, 106(7), 2353-2358.

Lee-Six, H., Obro, N. F., Shepherd, M. S., Grossmann, S., Dawson, K., Belmonte, M., . . Campbell, P. J. (2018). Population dynamics of normal human blood inferred from somatic mutations. Nature, 561(7724), 473-478.

Lensch, M. W. (2012). An evolving model of hematopoietic stem cell functional identity. Stem Cell Rev, 8(2), 551-560.

Leslie, N. R., Bennett, D., Lindsay, Y. E., Stewart, H., Gray, A. \& Downes, C. P. (2003). Redox regulation of PI 3-kinase signalling via inactivation of PTEN. EMBO J, 22(20), 5501-5510.

Levesque, J. P., Winkler, I. G., Hendy, J., Williams, B., Helwani, F., Barbier, V., . . Nilsson, S. K. (2007). Hematopoietic progenitor cell mobilization results in hypoxia with increased hypoxiainducible transcription factor-1 alpha and vascular endothelial growth factor A in bone marrow. Stem Cells, 25(8), 1954-1965.

Li, C. L. \& Johnson, G. R. (1992). Rhodamine123 reveals heterogeneity within murine Lin-, Sca-1+ hemopoietic stem cells. J Exp Med, 175(6), 1443-1447.

Li, C. L. \& Johnson, G. R. (1995). Murine hematopoietic stem and progenitor cells: I. Enrichment and biologic characterization. Blood, 85(6), 1472-1479.

Li, H., Ko, H. P. \& Whitlock, J. P. (1996). Induction of phosphoglycerate kinase 1 gene expression by hypoxia. Roles of Arnt and HIF1alpha. J Biol Chem, 271(35), 21262-21267.

Liu, Y., Elf, S. E., Miyata, Y., Sashida, G., Liu, Y., Huang, G., . . Nimer, S. D. (2009). p53 regulates hematopoietic stem cell quiescence. Cell Stem Cell, 4(1), 37-48.

Lo Celso, C., Fleming, H. E., Wu, J. W., Zhao, C. X., Miake-Lye, S., Fujisaki, J., . . Scadden, D. T. (2009). Live-animal tracking of individual haematopoietic stem/progenitor cells in their niche. Nature, 457(7225), 92-96. 
Lodish, H., Berk, A., S.L., Z. \& al., e. (2000). Molecular Cell Biology. 4th edition. Section 16.1, Oxidation of Glucose and Fatty Acids to CO2. New York: Freeman, W.H.

Lozzio, C. B. \& Lozzio, B. B. (1975). Human chronic myelogenous leukemia cell-line with positive Philadelphia chromosome. Blood, 45(3), 321-334.

Mahon, P. C., Hirota, K. \& Semenza, G. L. (2001). FIH-1: a novel protein that interacts with HIF1alpha and VHL to mediate repression of HIF-1 transcriptional activity. Genes Dev, 15(20), 2675-2686.

Makino, Y., Cao, R., Svensson, K., Bertilsson, G., Asman, M., Tanaka, H., . . Poellinger, L. (2001). Inhibitory PAS domain protein is a negative regulator of hypoxia-inducible gene expression. Nature, 414(6863), 550-554.

Martin, C. M., Ferdous, A., Gallardo, T., Humphries, C., Sadek, H., Caprioli, A., . . . Garry, D. J. (2008). Hypoxia-inducible factor-2alpha transactivates Abcg2 and promotes cytoprotection in cardiac side population cells. Circ Res, 102(9), 1075-1081.

Martinez-Agosto, J. A., Mikkola, H. K., Hartenstein, V. \& Banerjee, U. (2007). The hematopoietic stem cell and its niche: a comparative view. Genes Dev, 21(23), 3044-3060.

Marzac, C., Garrido, E., Tang, R., Fava, F., Hirsch, P., De Benedictis, C., . . Legrand, O. (2011). ATP Binding Cassette transporters associated with chemoresistance: transcriptional profiling in extreme cohorts and their prognostic impact in a cohort of 281 acute myeloid leukemia patients. Haematologica, 96(9), 1293-1301.

Maxwell, P. H., Wiesener, M. S., Chang, G. W., Clifford, S. C., Vaux, E. C., Cockman, M. E., . . . Ratcliffe, P. J. (1999). The tumour suppressor protein VHL targets hypoxia-inducible factors for oxygen-dependent proteolysis. Nature, 399(6733), 271-275.

Melo, J. V. \& Barnes, D. J. (2007). Chronic myeloid leukaemia as a model of disease evolution in human cancer. Nat Rev Cancer, 7(6), 441-453.

Melvin, A., Mudie, S. \& Rocha, S. (2011). Further insights into the mechanism of hypoxia-induced NFkappaB. [corrected]. Cell Cycle, 10(6), 879-882.

Mendez-Ferrer, S., Michurina, T. V., Ferraro, F., Mazloom, A. R., Macarthur, B. D., Lira, S. A., . . . Frenette, P. S. (2010). Mesenchymal and haematopoietic stem cells form a unique bone marrow niche. Nature, 466(7308), 829-834.

Mihara, M., Hashizume, M., Yoshida, H., Suzuki, M. \& Shiina, M. (2012). IL-6/IL-6 receptor system and its role in physiological and pathological conditions. Clin Sci (Lond), 122(4), 143-159.

Miharada, K., Karlsson, G., Rehn, M., Rorby, E., Siva, K., Cammenga, J. \& Karlsson, S. (2011). Cripto regulates hematopoietic stem cells as a hypoxic-niche-related factor through cell surface receptor GRP78. Cell Stem Cell, 9(4), 330-344.

Miller, C. L. \& Eaves, C. J. (1997). Expansion in vitro of adult murine hematopoietic stem cells with transplantable lympho-myeloid reconstituting ability. Proc Natl Acad Sci U S A, 94(25), 13648-13653.

Miyamoto, K., Araki, K. Y., Naka, K., Arai, F., Takubo, K., Yamazaki, S., . . . Hirao, A. (2007). Foxo3a is essential for maintenance of the hematopoietic stem cell pool. Cell Stem Cell, 1(1), 101-112.

Molofsky, A. V., Pardal, R. \& Morrison, S. J. (2004). Diverse mechanisms regulate stem cell selfrenewal. Curr Opin Cell Biol, 16(6), 700-707.

Morrison, S. J. \& Scadden, D. T. (2014). The bone marrow niche for haematopoietic stem cells. Nature, 505(7483), 327-334.

Morrison, S. J., Wandycz, A. M., Hemmati, H. D., Wright, D. E. \& Weissman, I. L. (1997). Identification of a lineage of multipotent hematopoietic progenitors. Development, 124(10), 1929-1939.

Morrison, S. J. \& Weissman, I. L. (1994). The long-term repopulating subset of hematopoietic stem cells is deterministic and isolatable by phenotype. Immunity, 1(8), 661-673.

Nervi, B., Ramirez, P., Rettig, M. P., Uy, G. L., Holt, M. S., Ritchey, J. K., . . DiPersio, J. F. (2009). Chemosensitization of acute myeloid leukemia (AML) following mobilization by the CXCR4 antagonist AMD3100. Blood, 113(24), 6206-6214.

Ng, K. P., Manjeri, A., Lee, K. L., Huang, W., Tan, S. Y., Chuah, C. T., . . . Ong, S. T. (2014). Physiologic hypoxia promotes maintenance of CML stem cells despite effective BCR-ABL1 inhibition. Blood, 123(21), 3316-3326. 
Nita, M. \& Grzybowski, A. (2016). The Role of the Reactive Oxygen Species and Oxidative Stress in the Pathomechanism of the Age-Related Ocular Diseases and Other Pathologies of the Anterior and Posterior Eye Segments in Adults. Oxid Med Cell Longev, 2016, 3164734.

Nombela-Arrieta, C., Pivarnik, G., Winkel, B., Canty, K. J., Harley, B., Mahoney, J. E., . . . Silberstein, L. E. (2013). Quantitative imaging of haematopoietic stem and progenitor cell localization and hypoxic status in the bone marrow microenvironment. Nat Cell Biol, 15(5), 533-543.

O'Brien, S. G., Guilhot, F., Larson, R. A., Gathmann, I., Baccarani, M., Cervantes, F., . . . Investigators, I. (2003). Imatinib compared with interferon and low-dose cytarabine for newly diagnosed chronic-phase chronic myeloid leukemia. N Engl J Med, 348(11), 994-1004.

Ogawa, M. (1993). Differentiation and proliferation of hematopoietic stem cells. Blood, 81(11), 28442853.

Ogawa, M., Matsuzaki, Y., Nishikawa, S., Hayashi, S., Kunisada, T., Sudo, T., . . Nishikawa, S. (1991). Expression and function of c-kit in hemopoietic progenitor cells. J Exp Med, 174(1), 63-71.

Ogilvy, S., Metcalf, D., Print, C. G., Bath, M. L., Harris, A. W. \& Adams, J. M. (1999). Constitutive Bcl-2 expression throughout the hematopoietic compartment affects multiple lineages and enhances progenitor cell survival. Proc Natl Acad Sci U S A, 96(26), 14943-14948.

Okada, S., Nakauchi, H., Nagayoshi, K., Nishikawa, S., Miura, Y. \& Suda, T. (1992). In vivo and in vitro stem cell function of c-kit- and Sca-1-positive murine hematopoietic cells. Blood, 80(12), 3044-3050.

Oliver, K. M., Garvey, J. F., Ng, C. T., Veale, D. J., Fearon, U., Cummins, E. P. \& Taylor, C. T. (2009). Hypoxia activates NF-kappaB-dependent gene expression through the canonical signaling pathway. Antioxid Redox Signal, 11(9), 2057-2064.

Oostendorp, R. A., Audet, J. \& Eaves, C. J. (2000). High-resolution tracking of cell division suggests similar cell cycle kinetics of hematopoietic stem cells stimulated in vitro and in vivo. Blood, 95(3), 855-862.

Orrenius, S., Gogvadze, V. \& Zhivotovsky, B. (2007). Mitochondrial oxidative stress: implications for cell death. Annual review of pharmacology and toxicology, 47, 143-183.

Osawa, M., Hanada, K., Hamada, H. \& Nakauchi, H. (1996). Long-term lymphohematopoietic reconstitution by a single CD34-low/negative hematopoietic stem cell. Science, 273(5272), $242-245$.

Paguirigan, A. L., Smith, J., Meshinchi, S., Carroll, M., Maley, C. \& Radich, J. P. (2015). Single-cell genotyping demonstrates complex clonal diversity in acute myeloid leukemia. Sci Transl Med, $7(281), 281 \mathrm{re} 282$.

Pahl, H. L. (1999). Activators and target genes of Rel/NF-kappaB transcription factors. Oncogene, 18(49), 6853-6866.

Pang, W. W., Price, E. A., Sahoo, D., Beerman, I., Maloney, W. J., Rossi, D. J., . . Weissman, I. L. (2011). Human bone marrow hematopoietic stem cells are increased in frequency and myeloid-biased with age. Proc Natl Acad Sci U S A, 108(50), 20012-20017.

Parmar, K., Mauch, P., Vergilio, J. A., Sackstein, R. \& Down, J. D. (2007). Distribution of hematopoietic stem cells in the bone marrow according to regional hypoxia. Proc Natl Acad Sci U S A, 104(13), 5431-5436.

Perkins, N. D. (2006). Post-translational modifications regulating the activity and function of the nuclear factor kappa B pathway. Oncogene, 25(51), 6717-6730.

Perkins, N. D. (2007). Integrating cell-signalling pathways with NF-kappaB and IKK function. Nat Rev Mol Cell Biol, 8(1), 49-62.

Petit, I., Szyper-Kravitz, M., Nagler, A., Lahav, M., Peled, A., Habler, L., . . . Lapidot, T. (2002). GCSF induces stem cell mobilization by decreasing bone marrow SDF-1 and up-regulating CXCR4. Nat Immunol, 3(7), 687-694.

Picot, J., Guerin, C. L., Le Van Kim, C. \& Boulanger, C. M. (2012). Flow cytometry: retrospective, fundamentals and recent instrumentation. Cytotechnology, 64(2), 109-130.

Pierce, J. W., Schoenleber, R., Jesmok, G., Best, J., Moore, S. A., Collins, T. \& Gerritsen, M. E. (1997). Novel inhibitors of cytokine-induced IkappaBalpha phosphorylation and endothelial cell adhesion molecule expression show anti-inflammatory effects in vivo. J Biol Chem, 272(34), 21096-21103. 
Piloto, O., Wright, M., Brown, P., Kim, K. T., Levis, M. \& Small, D. (2007). Prolonged exposure to FLT3 inhibitors leads to resistance via activation of parallel signaling pathways. Blood, 109(4), 1643-1652.

Poch Martell, M., Sibai, H., Deotare, U. \& Lipton, J. H. (2016). Ponatinib in the therapy of chronic myeloid leukemia. Expert Rev Hematol, 9(10), 923-932.

Pommier, Y., Leo, E., Zhang, H. \& Marchand, C. (2010). DNA topoisomerases and their poisoning by anticancer and antibacterial drugs. Chem Biol, 17(5), 421-433.

Prieto-Bermejo, R., Romo-Gonzalez, M., Perez-Fernandez, A., Ijurko, C. \& Hernandez-Hernandez, A. (2018). Reactive oxygen species in haematopoiesis: leukaemic cells take a walk on the wild side. J Exp Clin Cancer Res, 37(1), 125.

Qiu, J., Papatsenko, D., Niu, X., Schaniel, C. \& Moore, K. (2014). Divisional history and hematopoietic stem cell function during homeostasis. Stem Cell Reports, 2(4), 473-490.

Quentmeier, H., Reinhardt, J., Zaborski, M. \& Drexler, H. G. (2003). FLT3 mutations in acute myeloid leukemia cell lines. Leukemia, 17(1), 120-124.

Quintas-Cardama, A. \& Cortes, J. (2009). Molecular biology of bcr-abl1-positive chronic myeloid leukemia. Blood, 113(8), 1619-1630.

Randall, T. D., Lund, F. E., Howard, M. C. \& Weissman, I. L. (1996). Expression of murine CD38 defines a population of long-term reconstituting hematopoietic stem cells. Blood, 87(10), 4057-4067.

Reber, L., Da Silva, C. A. \& Frossard, N. (2006). Stem cell factor and its receptor c-Kit as targets for inflammatory diseases. Eur J Pharmacol, 533(1-3), 327-340.

Rehman, J. (2010). Empowering self-renewal and differentiation: the role of mitochondria in stem cells. J Mol Med (Berl), 88(10), 981-986.

Robinson, S. N., Ng, J., Niu, T., Yang, H., McMannis, J. D., Karandish, S., . . . Shpall, E. J. (2006). Superior ex vivo cord blood expansion following co-culture with bone marrow-derived mesenchymal stem cells. Bone Marrow Transplant, 37(4), 359-366.

Roe, T., Reynolds, T. C., Yu, G. \& Brown, P. O. (1993). Integration of murine leukemia virus DNA depends on mitosis. EMBO J, 12(5), 2099-2108.

Rolink, A., ten Boekel, E., Melchers, F., Fearon, D. T., Krop, I. \& Andersson, J. (1996). A subpopulation of B220+ cells in murine bone marrow does not express CD19 and contains natural killer cell progenitors. J Exp Med, 183(1), 187-194.

Rouault-Pierre, K., Lopez-Onieva, L., Foster, K., Anjos-Afonso, F., Lamrissi-Garcia, I., SerranoSanchez, M., . . . Bonnet, D. (2013). HIF-2alpha protects human hematopoietic stem/progenitors and acute myeloid leukemic cells from apoptosis induced by endoplasmic reticulum stress. Cell Stem Cell, 13(5), 549-563.

Rowley, J. D. (1973). Letter: A new consistent chromosomal abnormality in chronic myelogenous leukaemia identified by quinacrine fluorescence and Giemsa staining. Nature, 243(5405), 290293.

Ryan, H. E., Poloni, M., McNulty, W., Elson, D., Gassmann, M., Arbeit, J. M. \& Johnson, R. S. (2000). Hypoxia-inducible factor-1alpha is a positive factor in solid tumor growth. Cancer Res, $60(15), 4010-4015$.

Rörby, E. (2014). Regulation of Hematopoietic Stem Cells. (Doctoral thesis), Lund University, Lund.

Sakurai, H., Chiba, H., Miyoshi, H., Sugita, T. \& Toriumi, W. (1999). IkappaB kinases phosphorylate NF-kappaB p65 subunit on serine 536 in the transactivation domain. J Biol Chem, 274(43), 30353-30356.

Sallmyr, A., Fan, J. \& Rassool, F. V. (2008). Genomic instability in myeloid malignancies: increased reactive oxygen species (ROS), DNA double strand breaks (DSBs) and error-prone repair. Cancer Lett, 270(1), 1-9.

Schofield, R. (1978). The relationship between the spleen colony-forming cell and the haemopoietic stem cell. Blood Cells, 4(1-2), 7-25.

Scortegagna, M., Ding, K., Oktay, Y., Gaur, A., Thurmond, F., Yan, L. J., . . Garcia, J. A. (2003). Multiple organ pathology, metabolic abnormalities and impaired homeostasis of reactive oxygen species in Epas1-/- mice. Nat Genet, 35(4), 331-340. 
Semenza, G. L., Nejfelt, M. K., Chi, S. M. \& Antonarakis, S. E. (1991). Hypoxia-inducible nuclear factors bind to an enhancer element located 3 ' to the human erythropoietin gene. Proc Natl Acad Sci U S A, 88(13), 5680-5684.

Sen, R. \& Baltimore, D. (1986). Multiple nuclear factors interact with the immunoglobulin enhancer sequences. Cell, 46(5), 705-716.

Sharma, Y., Astle, C. M. \& Harrison, D. E. (2007). Heterozygous kit mutants with little or no apparent anemia exhibit large defects in overall hematopoietic stem cell function. Exp Hematol, 35(2), 214-220.

Shih, A. H., Jiang, Y., Meydan, C., Shank, K., Pandey, S., Barreyro, L., . . . Levine, R. L. (2015). Mutational cooperativity linked to combinatorial epigenetic gain of function in acute myeloid leukemia. Cancer Cell, 27(4), 502-515.

Shima, H., Takubo, K., Iwasaki, H., Yoshihara, H., Gomei, Y., Hosokawa, K., . . Suda, T. (2009). Reconstitution activity of hypoxic cultured human cord blood CD34-positive cells in NOG mice. Biochemical and biophysical research communications, 378(3), 467-472.

Shima, H., Takubo, K., Tago, N., Iwasaki, H., Arai, F., Takahashi, T. \& Suda, T. (2010). Acquisition of $\mathrm{G}(0)$ state by $\mathrm{CD} 34$-positive cord blood cells after bone marrow transplantation. Exp Hematol, 38(12), 1231-1240.

Shinohara, A., Imai, Y., Nakagawa, M., Takahashi, T., Ichikawa, M. \& Kurokawa, M. (2014). Intracellular reactive oxygen species mark and influence the megakaryocyte-erythrocyte progenitor fate of common myeloid progenitors. Stem Cells, 32(2), 548-557.

Shlush, L. I. \& Mitchell, A. (2015). AML evolution from preleukemia to leukemia and relapse. Best Pract Res Clin Haematol, 28(2-3), 81-89.

Shpall, E. J., Quinones, R., Giller, R., Zeng, C., Baron, A. E., Jones, R. B., . . McNiece, I. K. (2002). Transplantation of ex vivo expanded cord blood. Biol Blood Marrow Transplant, 8(7), 368376.

Shtivelman, E., Lifshitz, B., Gale, R. P., Roe, B. A. \& Canaani, E. (1986). Alternative splicing of RNAs transcribed from the human abl gene and from the bcr-abl fused gene. Cell, 47(2), 277284.

Simon, M. C. \& Keith, B. (2008). The role of oxygen availability in embryonic development and stem cell function. Nat Rev Mol Cell Biol, 9(4), 285-296.

Simsek, T., Kocabas, F., Zheng, J., Deberardinis, R. J., Mahmoud, A. I., Olson, E. N., . . Sadek, H. A. (2010). The distinct metabolic profile of hematopoietic stem cells reflects their location in a hypoxic niche. Cell Stem Cell, 7(3), 380-390.

Sison, E. A., McIntyre, E., Magoon, D. \& Brown, P. (2013). Dynamic chemotherapy-induced upregulation of CXCR4 expression: a mechanism of therapeutic resistance in pediatric AML. Mol Cancer Res, 11(9), 1004-1016.

Smith, B. D., Levis, M., Beran, M., Giles, F., Kantarjian, H., Berg, K., . . Small, D. (2004). Singleagent CEP-701, a novel FLT3 inhibitor, shows biologic and clinical activity in patients with relapsed or refractory acute myeloid leukemia. Blood, 103(10), 3669-3676.

Solar, G. P., Kerr, W. G., Zeigler, F. C., Hess, D., Donahue, C., de Sauvage, F. J. \& Eaton, D. L. (1998). Role of c-mpl in early hematopoiesis. Blood, 92(1), 4-10.

Spangrude, G. J., Heimfeld, S. \& Weissman, I. L. (1988). Purification and characterization of mouse hematopoietic stem cells. Science, 241(4861), 58-62.

Spencer, J. A., Ferraro, F., Roussakis, E., Klein, A., Wu, J., Runnels, J. M., . . . Lin, C. P. (2014). Direct measurement of local oxygen concentration in the bone marrow of live animals. Nature.

Stein, S. J. \& Baldwin, A. S. (2013). Deletion of the NF-kappaB subunit p65/RelA in the hematopoietic compartment leads to defects in hematopoietic stem cell function. Blood, 121(25), 5015-5024.

Stone, R. M., Mandrekar, S. J., Sanford, B. L., Geyer, S., Bloomfield, C. D., Dohner, K., . . Dohner, H. (2015). The Multi-Kinase Inhibitor Midostaurin (M) Prolongs Survival Compared with Placebo (P) in Combination with Daunorubicin (D)/Cytarabine (C) Induction (ind), HighDose C Consolidation (consol), and As Maintenance (maint) Therapy in Newly Diagnosed Acute Myeloid Leukemia (AML) Patients (pts) Age 18-60 with FLT3 Mutations (muts): An International Prospective Randomized (rand) P-Controlled Double-Blind Trial (CALGB 10603/RATIFY [Alliance]). Blood, 126(23), Abstract 6. 
Stone, R. M., Mandrekar, S. J., Sanford, B. L., Laumann, K., Geyer, S., Bloomfield, C. D., . . Dohner, H. (2017). Midostaurin plus Chemotherapy for Acute Myeloid Leukemia with a FLT3 Mutation. N Engl J Med, 377(5), 454-464.

Stromskaya, T. P., Rybalkina, E. Y., Kruglov, S. S., Zabotina, T. N., Mechetner, E. B., Turkina, A. G. \& Stavrovskaya, A. A. (2008). Role of P-glycoprotein in evolution of populations of chronic myeloid leukemia cells treated with imatinib. Biochemistry (Mosc), 73(1), 29-37.

Suda, T., Takubo, K. \& Semenza, G. L. (2011). Metabolic regulation of hematopoietic stem cells in the hypoxic niche. Cell Stem Cell, 9(4), 298-310.

Sutherland, H. J., Eaves, C. J., Eaves, A. C., Dragowska, W. \& Lansdorp, P. M. (1989). Characterization and partial purification of human marrow cells capable of initiating longterm hematopoiesis in vitro. Blood, 74(5), 1563-1570.

Suzuki, T., Yokoyama, Y., Kumano, K., Takanashi, M., Kozuma, S., Takato, T., . . Chiba, S. (2006). Highly efficient ex vivo expansion of human hematopoietic stem cells using Delta1-Fc chimeric protein. Stem Cells, 24(11), 2456-2465.

Svirnovski, A. I., Shman, T. V., Serhiyenka, T. F., Savitski, V. P., Smolnikova, V. V. \& Fedasenka, U. U. (2009). ABCB1 and ABCG2 proteins, their functional activity and gene expression in concert with drug sensitivity of leukemia cells. Hematology, 14(4), 204-212.

Taichman, R. S. \& Emerson, S. G. (1994). Human osteoblasts support hematopoiesis through the production of granulocyte colony-stimulating factor. J Exp Med, 179(5), 1677-1682.

Takubo, K., Goda, N., Yamada, W., Iriuchishima, H., Ikeda, E., Kubota, Y., . . . Suda, T. (2010). Regulation of the HIF-1alpha level is essential for hematopoietic stem cells. Cell Stem Cell, 7(3), 391-402.

Takubo, K., Nagamatsu, G., Kobayashi, C. I., Nakamura-Ishizu, A., Kobayashi, H., Ikeda, E., . . . Suda, T. (2013). Regulation of glycolysis by Pdk functions as a metabolic checkpoint for cell cycle quiescence in hematopoietic stem cells. Cell Stem Cell, 12(1), 49-61.

Terstappen, L. W., Huang, S., Safford, M., Lansdorp, P. M. \& Loken, M. R. (1991). Sequential generations of hematopoietic colonies derived from single nonlineage-committed CD34+CD38- progenitor cells. Blood, 77(6), 1218-1227.

Thomas, E. D., Lochte, H. L., Jr., Lu, W. C. \& Ferrebee, J. W. (1957). Intravenous infusion of bone marrow in patients receiving radiation and chemotherapy. N Engl J Med, 257(11), 491-496.

Thoren, L. A., Liuba, K., Bryder, D., Nygren, J. M., Jensen, C. T., Qian, H., . . Jacobsen, S. E. (2008). Kit regulates maintenance of quiescent hematopoietic stem cells. J Immunol, 180(4), 20452053.

Till, J. E. \& Mc, C. E. (1961). A direct measurement of the radiation sensitivity of normal mouse bone marrow cells. Radiat Res, 14, 213-222.

Tothova, Z., Kollipara, R., Huntly, B. J., Lee, B. H., Castrillon, D. H., Cullen, D. E., . . G Gilliland, D. G. (2007). FoxOs are critical mediators of hematopoietic stem cell resistance to physiologic oxidative stress. Cell, 128(2), 325-339.

Tsuchiya, S., Yamabe, M., Yamaguchi, Y., Kobayashi, Y., Konno, T. \& Tada, K. (1980). Establishment and characterization of a human acute monocytic leukemia cell line (THP-1). Int J Cancer, 26(2), 171-176.

Urao, N. \& Ushio-Fukai, M. (2013). Redox regulation of stem/progenitor cells and bone marrow niche. Free Radic Biol Med, 54, 26-39.

Velasco-Hernandez, T., Hyrenius-Wittsten, A., Rehn, M., Bryder, D. \& Cammenga, J. (2014). HIF1alpha can act as a tumor suppressor gene in murine acute myeloid leukemia. Blood, 124(24), 3597-3607.

Velasco-Hernandez, T., Tornero, D. \& Cammenga, J. (2015). Loss of HIF-1alpha accelerates murine FLT-3(ITD)-induced myeloproliferative neoplasia. Leukemia, 29(12), 2366-2374.

Vukovic, M., Guitart, A. V., Sepulveda, C., Villacreces, A., O'Duibhir, E., Panagopoulou, T. I., . . . Kranc, K. R. (2015). Hif-1alpha and Hif-2alpha synergize to suppress AML development but are dispensable for disease maintenance. J Exp Med, 212(13), 2223-2234.

Vukovic, M., Sepulveda, C., Subramani, C., Guitart, A. V., Mohr, J., Allen, L., . . . Kranc, K. R. (2016). Adult hematopoietic stem cells lacking Hif-1alpha self-renew normally. Blood, 127(23), 2841-2846. 
Wagner, J. E., Jr., Brunstein, C. G., Boitano, A. E., DeFor, T. E., McKenna, D., Sumstad, D., . . Bleul, C. C. (2016). Phase I/II Trial of StemRegenin-1 Expanded Umbilical Cord Blood Hematopoietic Stem Cells Supports Testing as a Stand-Alone Graft. Cell Stem Cell, 18(1), 144-155.

Walenda, T., Bork, S., Horn, P., Wein, F., Saffrich, R., Diehlmann, A., . . Wagner, W. (2010). Coculture with mesenchymal stromal cells increases proliferation and maintenance of haematopoietic progenitor cells. J Cell Mol Med, 14(1-2), 337-350.

Wang, G. L., Jiang, B. H., Rue, E. A. \& Semenza, G. L. (1995). Hypoxia-inducible factor 1 is a basichelix-loop-helix-PAS heterodimer regulated by cellular $\mathrm{O} 2$ tension. Proc Natl Acad Sci U S A, 92(12), 5510-5514.

Wang, Y., Kellner, J., Liu, L. \& Zhou, D. (2011a). Inhibition of p38 mitogen-activated protein kinase promotes ex vivo hematopoietic stem cell expansion. Stem Cells Dev, 20(7), 1143-1152.

Wang, Y., Krivtsov, A. V., Sinha, A. U., North, T. E., Goessling, W., Feng, Z., . . Armstrong, S. A. (2010). The Wnt/beta-catenin pathway is required for the development of leukemia stem cells in AML. Science, 327(5973), 1650-1653.

Wang, Y., Liu, Y., Malek, S. N., Zheng, P. \& Liu, Y. (2011b). Targeting HIF1alpha eliminates cancer stem cells in hematological malignancies. Cell Stem Cell, 8(4), 399-411.

Wang, Y. H., Israelsen, W. J., Lee, D., Yu, V. W. C., Jeanson, N. T., Clish, C. B., . . Scadden, D. T. (2014). Cell-state-specific metabolic dependency in hematopoiesis and leukemogenesis. Cell, 158(6), 1309-1323.

Waskow, C. \& Rodewald, H. R. (2002). Lymphocyte development in neonatal and adult c-Kitdeficient (c-KitW/W) mice. Adv Exp Med Biol, 512, 1-10.

Weisberg, E., Azab, A. K., Manley, P. W., Kung, A. L., Christie, A. L., Bronson, R., . . Griffin, J. D. (2012). Inhibition of CXCR4 in CML cells disrupts their interaction with the bone marrow microenvironment and sensitizes them to nilotinib. Leukemia, 26(5), 985-990.

Weisberg, E., Boulton, C., Kelly, L. M., Manley, P., Fabbro, D., Meyer, T., . . Griffin, J. D. (2002). Inhibition of mutant FLT3 receptors in leukemia cells by the small molecule tyrosine kinase inhibitor PKC412. Cancer Cell, 1(5), 433-443.

Welch, J. S., Ley, T. J., Link, D. C., Miller, C. A., Larson, D. E., Koboldt, D. C., . . . Wilson, R. K. (2012). The origin and evolution of mutations in acute myeloid leukemia. Cell, 150(2), 264278.

West, J. D. \& Marnett, L. J. (2006). Endogenous reactive intermediates as modulators of cell signaling and cell death. Chem Res Toxicol, 19(2), 173-194.

Wiesener, M. S., Jurgensen, J. S., Rosenberger, C., Scholze, C. K., Horstrup, J. H., Warnecke, C., . . . Eckardt, K. U. (2003). Widespread hypoxia-inducible expression of HIF-2alpha in distinct cell populations of different organs. FASEB J, 17(2), 271-273.

Williams, D. A. (1993). Ex vivo expansion of hematopoietic stem and progenitor cells--robbing Peter to pay Paul? Blood, 81(12), 3169-3172.

Wilson, A., Laurenti, E., Oser, G., van der Wath, R. C., Blanco-Bose, W., Jaworski, M., . . Trumpp, A. (2008). Hematopoietic stem cells reversibly switch from dormancy to self-renewal during homeostasis and repair. Cell, 135(6), 1118-1129.

Wilson, A., Murphy, M. J., Oskarsson, T., Kaloulis, K., Bettess, M. D., Oser, G. M., . . Trumpp, A. (2004). c-Myc controls the balance between hematopoietic stem cell self-renewal and differentiation. Genes Dev, 18(22), 2747-2763.

Woll, P. S., Kjallquist, U., Chowdhury, O., Doolittle, H., Wedge, D. C., Thongjuea, S., . . Jacobsen, S. E. (2014). Myelodysplastic syndromes are propagated by rare and distinct human cancer stem cells in vivo. Cancer Cell, 25(6), 794-808.

Wu, J. Y., Purton, L. E., Rodda, S. J., Chen, M., Weinstein, L. S., McMahon, A. P., . . Kronenberg, H. M. (2008). Osteoblastic regulation of B lymphopoiesis is mediated by Gs \{alpha\}-dependent signaling pathways. Proc Natl Acad Sci U S A, 105(44), 16976-16981.

Xie, M., Lu, C., Wang, J., McLellan, M. D., Johnson, K. J., Wendl, M. C., . . Ding, L. (2014a). Agerelated mutations associated with clonal hematopoietic expansion and malignancies. Nat Med, 20(12), 1472-1478. 
Xie, X., Xiao, H., Ding, F., Zhong, H., Zhu, J., Ma, N. \& Mei, J. (2014b). Over-expression of prolyl hydroxylase-1 blocks NF-kappaB-mediated cyclin D1 expression and proliferation in lung carcinoma cells. Cancer Genet, 207(5), 188-194.

Yalcin, S., Zhang, X., Luciano, J. P., Mungamuri, S. K., Marinkovic, D., Vercherat, C., . . Ghaffari, S. (2008). Foxo3 is essential for the regulation of ataxia telangiectasia mutated and oxidative stress-mediated homeostasis of hematopoietic stem cells. J Biol Chem, 283(37), 25692-25705.

Yamamoto, R., Morita, Y., Ooehara, J., Hamanaka, S., Onodera, M., Rudolph, K. L., . . . Nakauchi, H. (2013). Clonal analysis unveils self-renewing lineage-restricted progenitors generated directly from hematopoietic stem cells. Cell, 154(5), 1112-1126.

Yamamoto, Y., Kiyoi, H., Nakano, Y., Suzuki, R., Kodera, Y., Miyawaki, S., . . Naoe, T. (2001). Activating mutation of D835 within the activation loop of FLT3 in human hematologic malignancies. Blood, 97(8), 2434-2439.

Yang, F., Kemp, C. J. \& Henikoff, S. (2015). Anthracyclines induce double-strand DNA breaks at active gene promoters. Mutat Res, 773, 9-15.

Yang, L., Bryder, D., Adolfsson, J., Nygren, J., Mansson, R., Sigvardsson, M. \& Jacobsen, S. E. (2005). Identification of Lin(-)Sca1(+)kit(+)CD34(+)Flt3- short-term hematopoietic stem cells capable of rapidly reconstituting and rescuing myeloablated transplant recipients. Blood, 105(7), 2717-2723.

Yates, J. W., Wallace, H. J., Jr., Ellison, R. R. \& Holland, J. F. (1973). Cytosine arabinoside (NSC63878) and daunorubicin (NSC-83142) therapy in acute nonlymphocytic leukemia. Cancer Chemother Rep, 57(4), 485-488.

Yoshihara, H., Arai, F., Hosokawa, K., Hagiwara, T., Takubo, K., Nakamura, Y., . . Suda, T. (2007). Thrombopoietin/MPL signaling regulates hematopoietic stem cell quiescence and interaction with the osteoblastic niche. Cell Stem Cell, 1(6), 685-697.

Yu, W. M., Liu, X., Shen, J., Jovanovic, O., Pohl, E. E., Gerson, S. L., . . . Qu, C. K. (2013). Metabolic regulation by the mitochondrial phosphatase PTPMT1 is required for hematopoietic stem cell differentiation. Cell Stem Cell, 12(1), 62-74.

Zafarullah, M., Li, W. Q., Sylvester, J. \& Ahmad, M. (2003). Molecular mechanisms of Nacetylcysteine actions. Cell Mol Life Sci, 60(1), 6-20.

Zeng, Z., Shi, Y. X., Samudio, I. J., Wang, R. Y., Ling, X., Frolova, O., . . Konopleva, M. (2009). Targeting the leukemia microenvironment by CXCR4 inhibition overcomes resistance to kinase inhibitors and chemotherapy in AML. Blood, 113(24), 6215-6224.

Zhang, D. D. \& Hannink, M. (2003). Distinct cysteine residues in Keap1 are required for Keap1dependent ubiquitination of Nrf2 and for stabilization of Nrf2 by chemopreventive agents and oxidative stress. Mol Cell Biol, 23(22), 8137-8151.

Zhang, H., Li, H., Xi, H. S. \& Li, S. (2012). HIF1alpha is required for survival maintenance of chronic myeloid leukemia stem cells. Blood, 119(11), 2595-2607.

Zhang, J., Niu, C., Ye, L., Huang, H., He, X., Tong, W. G., . . . Li, L. (2003). Identification of the haematopoietic stem cell niche and control of the niche size. Nature, 425(6960), 836-841.

Zhao, C., Xiu, Y., Ashton, J., Xing, L., Morita, Y., Jordan, C. T. \& Boyce, B. F. (2012). Noncanonical NF-kappaB signaling regulates hematopoietic stem cell self-renewal and microenvironment interactions. Stem Cells, 30(4), 709-718.

Zhong, H., SuYang, H., Erdjument-Bromage, H., Tempst, P. \& Ghosh, S. (1997). The transcriptional activity of NF-kappaB is regulated by the IkappaB-associated PKAc subunit through a cyclic AMP-independent mechanism. Cell, 89(3), 413-424.

Zhong, H., Voll, R. E. \& Ghosh, S. (1998). Phosphorylation of NF-kappa B p65 by PKA stimulates transcriptional activity by promoting a novel bivalent interaction with the coactivator CBP/p300. Mol Cell, 1(5), 661-671.

Zhou, B. O., Yue, R., Murphy, M. M., Peyer, J. G. \& Morrison, S. J. (2014). Leptin-receptorexpressing mesenchymal stromal cells represent the main source of bone formed by adult bone marrow. Cell Stem Cell, 15(2), 154-168.

Zhou, H. S., Carter, B. Z. \& Andreeff, M. (2016). Bone marrow niche-mediated survival of leukemia stem cells in acute myeloid leukemia: Yin and Yang. Cancer Biol Med, 13(2), 248-259. 


\section{Papers}

The papers associated with this thesis have been removed for copyright reasons. For more details about these see:

http://urn.kb.se/resolve?urn=urn:nbn:se:liu:diva-152129 